\title{
Moth flies (Diptera: Psychodidae) of the northern Hercynian Mountains and adjacent localities (Czech Republic)
}

\author{
Jan Ježek, Jozef Oboňa, Peter Manko \& Miloš Trýzna
}

\begin{abstract}
Moth flies (Diptera: Psychodidae) of the northern Hercynian Mountains and adjacent localities (Czech Republic). - Acta Mus. Siles. Sci. Natur. 70: 135-182, 2021.
\end{abstract}

\begin{abstract}
New faunistic data from the northern Hercynian Mountains and adjacent localities (Czech Republic) collected mostly at 52 sites in 2004-2010 are presented. Altogether, 88 species of moth flies (adults) of 38 genera (approximately $49 \%$ of all species of the family registered from the Czech Republic) are known to occur in this area. Twenty of these species were classified in the national Red List 2005 of threatened invertebrates and 14 are nationally scarce, suitable for further monitoring. Katamormia bezzii (Salamanna, 1983) and Berdeniella longispinosa (Vaillant, 1985) are new for Bohemia. In the appendix, the updated checklist of family Psychodidae is given for the Czech Republic and Slovakia.
\end{abstract}

Key words: Diptera, Psychodidae, Trichomyinae, Sycoracinae, Psychodinae, faunistics, České Švýcarsko NP, Labské pískovce PLA, Lužické hory PLA and its environment, northern Bohemia, Palaearctic Region, biodiversity, conservation potential, threatened species, new records, checklist.

\section{Introduction}

The nematocerous family Psychodidae is relatively well represented in the Palaearctic Region with well over 500 known species (Wagner 1990, 2018), more than 180 of which occur in the Czech Republic (Ježek 2009c, Ježek et al. 2012 and some unpublished new data; see Appendix - New checklist of moth flies of the Czech Republic and Slovakia and references).

Adult moth flies (size 2-3 mm), due to their features, are reminiscent of small butterflies of black, brown, grey, white or often combined colouring (Fig. 19), but always with only two mostly roof-like developed wings, with long antennae (up to 16 antennomeres) and a body covered with dense microsetae, bristles and scales. They occur mostly in wet shaded habitats. The larvae are saprophagous or coprophagous, except for urinophilic species sometimes. Members of the subfamily Sycoracinae suck the blood of frogs; Trichomyinae actively tunnel the rotting wood of fallen trees; Seoda and Clogmia are collected in phyto- or dendrotelmes; other genera often develop in decaying organic matter and leaf packs in peat-forming spring fens and mires (Clytocerus, Peripsychoda, Pneumia, Ulomyia), on gravel and stony fractions of substrate with calcium carbonate encrusted mats of bryophytes (Berdeniella, Pericoma, Tonnoiriella), in mollusc shells (Philosepedon), in sandy sediments (Parajungiella), in fungi (Chodopsycha), in the slime film covering stones in streams (Parabazarella) and in forest wallows (Logima).

Generally, dipterists have not visited the northern Bohemian Hercynicum in the past to collect moth flies, and almost nothing has thus far been published. New published records in the last decades are: Threticus lucifugus (Walker, 1856) - Šluknov (Ježek 1985); Panimerus falcariformis Wagner, 1977 - Meanders of the Chřibská Kamenice River; Seoda labeculosa (Eaton, 1893) - swamps between Jetřichovice and Starý Mlýn near the Jetřichovická Bělá Brook as well as localities in the vicinity of Vlčí Hora Mt.; Chodopsycha buxtoni (Withers, 1988) - Zadní Jetřichovice (all Ježek 2006a); Jungiella (J.) septentrionalis Krek, 1979 Růžovský vrch Hill; Jungiella (Psychocha) hassiaca Wagner, 1993 - Zadní Doubice and Brtnický most Bridge (Křinice River); Apsycha pusilla (Tonnoir, 1922) - a cattle farm in Srbská 
Kamenice; Berdeniella illiesi Wagner, 1973, and Berdeniella pyrenaica Vaillant, 1976 Brtnický potok Brook in the vicinity of Brtníky, also B. pyrenaica in wet meadows NE of Srbská Kamenice; Pericoma (Pachypericoma) nielseni Kvifte, 2010 (as formosa) - Brtnický most Bridge, Dolský mlýn Mill, Doubický potok Brook between Doubice and Dolní Chřibská and Pryskřičný důl Valley (all Ježek 2009a).

Our study aims are to present published, new and unpublished faunal data with the contribution of biodiversity research on moth flies (Diptera: Psychodidae) of the northern Hercynian Mountains and adjacent localities (Czech Republic).

\section{Material and methods}

This study is based on 1167 slides of moth flies. The material was collected in the northern Hercynicum of the Czech Republic (České Švýcarsko territory and adjacent localities: margins of the Labské pískovce Sandstones area and the Lužické hory Mts) between 2004 - 2010. A prime mover of the biodiversity research project was the cooperation between the managements of the National Park (NP) and the Protected Landscape Areas (PLAs) with the Department of Entomology of the National Museum, Prague. The general natural history of the whole studied areas (the NP and partially the PLAs) was characterized mainly by Patzelt (2011), with some interesting details added, e.g., by Blažej \& Trýzna (2007), Soldán et al. (2008, 2009), Bojková et al. (2010), Holešínská et al. (2010), Chvojka et al. (2010), Pižl et al. (2011), Härtel (2013, 2014), Bogush et al. (2015), Horák et al. (2015), Blažej et al. (2016), Preisler et al. (2019), Strejček et al. (2020), etc. Most of our material was recorded using Malaise traps (Figs 8, 11, 12,14) emptied in three weeks period; generally only the date on which the samples were removed is quoted in the list of material examined in the Results section, supplemented by yellow pan traps (Fig. 5) emergent traps (Figs 3, 6), sticky cartons or light equipment (Fig. 16) or individual collecting by sweep netting during many individual excursions financed by the project. The traps were emptied mainly by M. Trýzna (České Švýcarsko NP, Krásná Lípa), sometimes additionally by the team of P. Chvojka, J. Ježek and J. Macek (all National Museum, Prague),or infrequently by VÚLHM (Výzkumný ústav lesního hospodářství a myslivosti / Forestry and Game Management Research Institute). The names of collectors of individual activities are always mentioned in the text. The captured moth flies were preserved in $70 \%$ ethanol in the field and subsequently cleared in chloralphenol, treated in xylol, determined by the first author and mounted on glass slides in Canada balsam. The voucher specimens are deposited in the National Museum, Prague, Czech Republic (NMPC). Slides were numbered in the NMPC by INS = Inventory Slide Number of the family Psychodidae (see Tkoč et al. 2014). Most of the recent data comes from a total of 52 localities; see the numbered list of collecting sites prepared in correspondence with the maps used: Národní park České Švýcarsko, Geodézie, 1:25000, Krásná Lípa; Českosaské Švýcarsko and Šluknovsko, SHOCart, 1:50000, Vizovice; Národní parky České a Saské Švýcarsko, TRASA, 1:50000, Prague. Coordinates: the places of trap installation were often changed locally by tens of metres during the quoted seasons in the same space, in contrast to the mentioned single GPS. Detailed information were included and supplied with the codes of fields in the faunistic and floristic grid mapping system for Central Europe (Ehrendorfer \& Hamann 1965, Zelený 1972, Pruner \& Míka 1996).

Identification keys used: Vaillant (1971-1983), Szabó (1983), Withers (1989a) and numerous unnamed original papers by different authors with descriptions of new species. The nomenclature is modified from Vaillant (1971-1983) and Wagner (1990, 2018) using the classifications of e.g. Ježek \& van Harten (2005, 2009), Ježek (2007), Omelková \& Ježek (2012a), Oboňa \& Ježek (2014), Kvifte (2014) and Kroča \& Ježek (2015).

Abbreviations: MSNM - Museo di Storia Naturale di Milano, MT - Malaise trap, YPT - yellow pan traps, ET - emergent trap, SC - sticky cartons, SW - sweeping, INS - number of slide (canadian balsam) deposited in the National Musem, $\hat{\sigma}$ - male, $q$ - female, CR - critically endangered, EN - endangered, VU - vulnerable, NS - species not assessed in red list (Ježek 2005), ČÚZK - Český úřad zeměměřický a katastrální / Czech Office for Surveying, IPF TUD - Institut für Photogrammetrie und Fernerkundung, Technische Universität Dresden, GeoSN - Staatsbetrieb Geobasisinformation und Vermessung Sachsen, GeoBasis-DE / BKG - Bundesamt für Kartographie und Geodäsie, LfULG - Sächsisches Landesamt für Umwelt, Landwirtschaft und Geologie, SNPČŠ - Správa Národního parku České Švýcarsko / The Bohemian Switzerland National Park Administration.

\section{LIST OF ALL COLLECTING AREAS}

(See maps 1, 2 and figs 1, 2, 4, 7, 9, 10, 13, 15, 17, 18)

1. between Dolský mlýn Mill and Královský smrk Spruce, confluence of Kamenice River and Jetřichovická Bělá Brook, ca. $50^{\circ} 50^{\prime} \mathrm{N}, 14^{\circ} 21^{\prime} \mathrm{E}, 195 \mathrm{~m}$ a.s.1., 5152; very old ruin of mill in wooded landscape; veg.: Pinus, Picea, Betula, Ulmus, Acer, Carpinus, Corylus, Carex, Caltha, Urtica, Batrachium, Pteropsida, Musci. 
2. between Doubice and Dolní Chřibská, U červeného kř́že Cross - Kraví roklinka Clough, Doubický potok Brook, ca. $50^{\circ} 52^{\prime} \mathrm{N}, 14^{\circ} 26^{\prime} \mathrm{E}, 370 \mathrm{~m}$ a.s.l., 5152; partially wooded area, fields and pastures; veg.: Picea, Sorbus, Betula, Tilia, Alnus, Fraxinus, Carpinus, Salix, Rubus, Carex, Pteropsida, Musci.

3. between Jetřichovice and Starý mlýn Mill, marches near road, ca. $50^{\circ} 51^{\prime} \mathrm{N}, 14^{\circ} 22^{\prime} \mathrm{E}, 232 \mathrm{~m}$ a.s.l., 5152; veg.: Alnus, Salix, Carex, Juncus, Pteropsida.

4. between Vlčí Hora and Brtníky, brook near road, ca. 50 56' N, 142ㄱ'E, $424 \mathrm{~m}$ a.s.l., 5052; edge of a forest, arable land; veg.: Alnus, Salix, Corylus, Carex, Juncus, Caltha, Pteropsida.

5. between Vysoká Lípa and Jetřichovice, dried forest brook, ca. $50^{\circ} 51^{\prime} \mathrm{N}, 14^{\circ} 22^{\prime} \mathrm{E}, 242 \mathrm{~m}$ a.s.1., 5152; veg.: Picea, Pinus, Betula, Alnus, Salix, Carex, Juncus, Pteropsida.

6. Bílý potok Brook env. Zadní Doubice-Hinterhermsdorf, above the confluence to Křinice River. ca. $50^{\circ} 55^{\prime} \mathrm{N}$, $14^{\circ} 24^{\prime} \mathrm{E}, 290 \mathrm{~m}$ a.s.l., 5052; Ash-alder meadow, on the slopes of the spruce monoculture valley; veg.: Alnus, Picea; Carex, Cirsium, Festuca, Petasites, Scirpus, Stachys, Stellaria.

7. Brtnický most Bridge, valley floodplain at the confluence of Křinice River, Brtnický and Bílý potok brooks env. Brtníky, ca. $50^{\circ} 55^{\prime} \mathrm{N}, 14^{\circ} 24^{\prime} \mathrm{E}, 295$ m a.s.l., 5052; wooded rocky area; veg.: Alnus, Fraxinus, Tilia, Acer, Picea, Larix, Carex, Juncus, Scirpus, Pteropsida.

8. Brtnický potok Brook env. Brtníky, south of the settlement Kopec at the lower course of the brook about $0.6 \mathrm{~km}$ above its confluence into Křinice river, ca. $50^{\circ} 55^{\prime} \mathrm{N}, 14^{\circ} 24^{\prime} \mathrm{E}, 295 \mathrm{~m}$ a.s.l., 5052; veg.: Aegopodium, Carex, Chaerophyllum, Cirsium, Petasites, Stachys, Stellaria, Urtica.

9. Brtníky env. Mikulášovice, Brtnický potok Brook, forest margin, ca. $50^{\circ} 56^{\prime} \mathrm{N}, 14^{\circ} 24^{\prime} \mathrm{E}, 373 \mathrm{~m}$ a.s.1., 5052; veg.: Picea, Alnus, Ribes, Scirpus, Caltha, Typha, Carex, Filipendula, Urtica, Myosotis, Petasites.

10. Brtníky x Mikulášovice, Nejsvatější Trojice Chapel, wet meadow N, forest brook, ca. $50^{\circ} 57^{\prime} \mathrm{N}, 14^{\circ} 24^{\prime} \mathrm{E}$, 470 m a.s.l., 5052; veg.: Alnus, Rubus, Impatiens, Myosotis, Scirpus, Pteropsida.

11. Dolský mlýn Mill env. Vysoká Lípa, meadow on the left bank of Kamenice River, ca. $50^{\circ} 50^{\prime} \mathrm{N}, 14^{\circ} 21^{\prime} \mathrm{E}$, 195 m a.s.l., 5152; veg.: Picea, Pinus, Betula, Tilia, Quercus, Salix, Alnus, Rubus, Carex, Juncus, Poaceae.

12. Doubice (settlement), brook, ca. $50^{\circ} 53^{\prime} \mathrm{N}, 14^{\circ} 27^{\prime} \mathrm{E}, 390 \mathrm{~m}$ a.s.l., 5152 ; fishpond cultivation, arable land; veg.: Picea, Sorbus, Betula, Tilia, Alnus, Fraxinus, Carpinus, Salix, Rubus, Carex, Pteropsida, Musci.

13. Ferdinandova soutěska Gulch, Kamenice River between Srbská Kamenice and Dolský mlýn Mill, ca. $50^{\circ} 50^{\prime} \mathrm{N}, 14^{\circ} 21^{\prime} \mathrm{E}, 230 \mathrm{~m}$ a.s.l., 5152; rocky wet walls, small streams; veg.: Picea, Pinus, Alnus, Pteropsida, Marchantiopsida, Bryopsida.

14. Hadí pramen Spring, $1.2 \mathrm{~km}$ south of the former settlement Zadní Doubice on a small left tributary Křinice. On a steep rocky slope, a spring and a stream with a wet sandstone wall and rocky humus crevices in an inverse gorge with cultural spruce, ca. $50^{\circ} 54^{\prime} \mathrm{N}, 14^{\circ} 23^{\prime} \mathrm{E}, 340 \mathrm{~m}$ a.s.1., 5052; veg.: Picea, Athyrium, Brachythecium, Calamagrostis, Carex, Cirsium, Conocephallum, Cratoneuron, Epilobium, Equisetum, Chaerophyllum, Deschampsia, Chrysosplenium, Mnium, Pellia, Plagio-mnium, Stachys, Urtica, Veronica, Viola.

15. Janov, settlement SE of Hřensko, ca. $50^{\circ} 51^{\prime} \mathrm{N}, 14^{\circ} 16^{\prime} \mathrm{E}, 323 \mathrm{~m}$ a.s.1., 5151; mixed forests, however, mainly Picea, meadows, small brooks and ponds.

16. Jetřichovice - Jetřichovice swimming pool, river Chřibská Kamenice, branches near water, ca. $50^{\circ} 50^{\prime} \mathrm{N}$, $14^{\circ} 23^{\prime} \mathrm{E}, 250 \mathrm{~m}$ a.s.l., 5152; veg.: Carpinus, Alnus, Urtica, Impatiens, Petasites, Daucaceae.

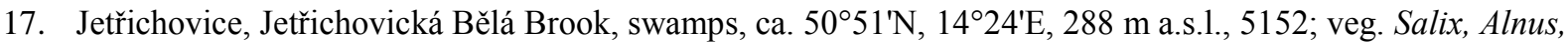
Carpinus, Urtica, Impatiens, Petasites, Carex, Juncus, Daucaceae, Pteropsida.

18. Kopec nr. Brtníky, tributary of the pond U Vyskočilů, floodplain, forest edge, ca. $50^{\circ} 56^{\prime} \mathrm{N}, 14^{\circ} 25^{\prime} \mathrm{E}, 370 \mathrm{~m}$ a.s.1., 5052; veg.: Picea, Alnus, Sambucus, Carex, Impatiens, Scirpus, Petasites, Urtica

19. Krásná Lípa env., brook near road in Rumburk, V končinách, ca. $50^{\circ} 56^{\prime} \mathrm{N}, 14^{\circ} 32^{\prime} \mathrm{E}, 420 \mathrm{~m}$ a.s.l., 5053; veg.: Alnus, Urtica, Myosotis, Carex, Filipendula, Scirpus.

20. Krásná Lípa, swamps near the pond „Pod tratí“, ca. 5055'N, $14^{\circ} 30^{\prime} \mathrm{E}, 443 \mathrm{~m}$ a.s.1., 5053; veg.: Betula, Salix, Populs, Filipendula, Myosotis, Menyanthes, Urtica, Caltha, Carex, Comarum, Galium.

21. Křinice River, Zadní Doubice env., valley floodplain with the meandering river Křinice, Ash-alder meadow, ca. $50^{\circ} 55^{\prime} \mathrm{N}, 14^{\circ} 24^{\prime} \mathrm{E}, 285 \mathrm{~m}$ a.s.l., 5052; veg.: Alnus, Salix; Aegopodium, Caltha, Carex, Cirsium, Festuca, Chaerophyllum, Chrysosplenium, Impatiens, Lamium, Phalaris, Ranunculus. Stachys, Stellaria, Urtica.

22. Limberk, mentioned in maps as well as Sokolí vrch Hill, $490.8 \mathrm{~m}$ a.s.l. (NW of Doubice), ca. $50^{\circ} 53^{\prime} \mathrm{N}$, $14^{\circ} 25^{\prime} \mathrm{E}, 400 \mathrm{~m}$ a.s.l., 5152; veg. Picea, Pinus, Betula and common plants of rocky areas.

23. Meanders of Chřibská Kamenice River N of Srbská Kamenice settlement, ca. $50^{\circ} 50^{\prime} \mathrm{N}, 14^{\circ} 21^{\prime} \mathrm{E}, 197-320 \mathrm{~m}$ a.s.l., 5152; veg.: Alnus, Salix, Betula and mainly common plants of wet meadows. 
24. Mezní Louka (southern part of the settlement), Kamenice River, ca. 5052'N, $14^{\circ} 19^{\prime} \mathrm{E}, 241 \mathrm{~m}$ a.s.1., 5152; veg.: Alnus, Betula, Tilia, Juglans, Pinus, Picea, Rubus, common alluvial plants and Poaceae.

25. Mikulášovice - upper railway station, two pasture ponds in the vicinity, arable land, ca. $50^{\circ} 58^{\prime} \mathrm{N}, 14^{\circ} 21^{\prime} \mathrm{E}$, 421 m a.s.1., 5052; veg.: Fraxinus, Alnus, Rubus, Filipendula, Caltha, Acorus, Nasturtium, Typha, Urtica.

26. Mlýny, northeast slope of the elevation $475 \mathrm{~m}$ a.s.l. env. Vysoká Lípa, spring stream, waterfall, sprinkled rocky wall in an older mixed forest. Forest meadow in a fragment of a flowery beech forest, ca. $50^{\circ} 52^{\prime} \mathrm{N}$, $14^{\circ} 22^{\prime}$ E, 352-440 m a.s.1., 5152; veg.: Picea, Pinus, Betula, Fraxinus, Salix, Alnus, common meadow plants, Pteropsida, Marchantiopsida, Musci.

27. Nad Edmundovou soutěskou Gulch (named as well Tichá soutěska gorge), $1 \mathrm{~km}$ north of Janov on the southern slope of Edmund's gorge, ca. $50^{\circ} 52^{\prime} \mathrm{N}, 14^{\circ} 15^{\prime} \mathrm{E}, 230 \mathrm{~m}$ a.s.1., 5151; rocky edge in a slope on a forest clearing under a rock overhang with swampy terraces and with spring cavities above the inverse sandstone gorge; dense spruce and beech thickets around; veg.: Picea, Fagus; Cardamine, Carex, Dryopteris, Gymnocarpium, Hookeria, Chrysosplenium, Juncus, Mnium, Molinia, Pellia, Poa, Polytrichum, Scapania, Sphagnum.

28. Pavlínino udoli Valley, between Jetřichovice, Rynartice and Studený, ca. $50^{\circ} 51{ }^{\prime} \mathrm{N}, 1^{\circ} 25^{\prime} \mathrm{E}, 300 \mathrm{~m}$ a.s.l., 5152; veg.: Picea, Betula, Pinus, Larix, Alnus, Carex, Juncus, Pteropsida, Marchantiopsida, Bryopsida.

29. Ponova louka Meadow, mesophilic forest meadow in a fragment of a flowery beech forest about $1.5 \mathrm{~km}$ north of the pension Mezní Louka, ca. 5053'N, 14²0'E, 420 m a.s.1., 5152; veg.: Picea, Pinus, Fagus, Digitalis and numerous green grass plants.

30. Pryskyřičný důl Valley - brook 4 km W of Doubice, ca. 5054'N, 14²4'E, $290 \mathrm{~m}$ a.s.1., 5152; a deep canyonshaped inverse gorge, whose bottom is formed by waterlogged spruce; veg.: Avenella, Bazzania, Calamagrostis, Carex, Digitalis, Oxalis, Polytrichum Pteridium, Trientalis, Vaccinium.

31. Pryskyřičný důl Valley - peat bogs, ca. 5053'N, 14²24'E, 290 m a.s.1., 5152; canyon with fallen trees, deep swamps, peat bogs; veg.: Picea, Sphagnum.

32. Růžovský vrch Hill env. Srbská Kamenice, ca. 5050'N, $14^{\circ} 20^{\prime} \mathrm{E}, 300-619 \mathrm{~m}$ a.s.1., 5152; spring wetlands and mesophilic meadows in the notch of the temporal watercourse on the eastern slope of the hill northwest of Srbská Kamenice. Rubble forest and flowery beech forest; veg.: Acer, Carpinus, Circea, Fagus, Fraxinus, Picea; Carex, Cardamine, Dryopteris, Festuca, Galium, Geum, Melica, Mercurialis, Pulmonaria, Rubus, Stachys, Stellaria, Urtica, Veronica.

33. Rybniště env. Krásná Lípa, tributary of Velký rybník Pond near the cemetery, ca. $50^{\circ} 53^{\prime} \mathrm{N}, 14^{\circ} 31^{\prime} \mathrm{E}, 451 \mathrm{~m}$ a.s.1., 5153; veg.: Salix, Alnus, Betula, Sambucus, Acer, Populus, Rubus, Filipendula, Polygonum, Urtica, Carex.

34. Rynartice, Weidlichova kaple Chapel, Chřribská Kamenice River, ca. 5051'N, 14²6'E, 304 m a.s.1., 5152; veg.: Picea, Pinus, Larix, Betula, Alnus, Carex, Juncus, Pteropsida, Marchantiopsida, Musci.

35. Severák $436 \mathrm{~m}$ a.s.l. env. Kopec. West-southwest of the settlement Kopec on the south-western slope of the locality elevation in the source area of the left-hand tributary of the Bílý potok Brook, ca. $50^{\circ} 56^{\prime} \mathrm{N}$, $14^{\circ} 24^{\prime} \mathrm{E}$, swamps $400 \mathrm{~m}$ a.s.1., 5052; wetland alder growing forest spring; veg.: Alnus; Caltha, Cardamine, Carex, Crepis, Equisetum, Ficaria. Stellaria.

36. Sněžná nr. Krásná Lípa (brook $0.5 \mathrm{~km} \mathrm{~S}$ ), cottages, polluted area, ca. $50^{\circ} 55^{\prime} \mathrm{N}, 14^{\circ} 28^{\prime} \mathrm{E}, 448 \mathrm{~m}$ a.s.1., 5052 ; veg.: Acer, Carpinus, Picea, Betula, Salix, Sorbus, Tilia, Caltha, Urtica, Filipendula, Petasites, Geum, Aegopodium.

37. Srbská Kamenice (north-eastern part), wet meadows, ca. 5050'N, 14²21'E, 222 m a.s.1., 5152; veg.: Salix, Alnus, Scirpus, Urtica, Ranunculus.

38. Srbská Kamenice (western part), moist sedge meadows, ca. 5049'N, 14²21'E, $301 \mathrm{~m}$ a.s.1, 5152; veg.: Salix, Alnus, Sambucus, Valeriana, Carex, Pteropsida.

39. Srbská Kamenice, a farm of cattle, ca. $50^{\circ} 49^{\prime} \mathrm{N}, 14^{\circ} 21^{\prime} \mathrm{E}, 250 \mathrm{~m}$ a.s.1., 5152; stable, manure.

40. Starý mlýn Mill nr. Jetřichovice, Jetřichovická Bělá Brook, ca. 5051'N, $14^{\circ} 22^{\prime} \mathrm{E}, 221$ m a.s.1., 5152; veg.: Picea, Pinus, Tilia, Salix, Betula, Alnus, Corylus, common plants of meadows, Pteropsida, Marchantiopsida, Musci. Arable land in the vicinity.

41. Suchá Bělá Brook nr. Hřensko, horizontal wet rocky cracks, ca. 5053'N, $14^{\circ} 15^{\prime} \mathrm{E}, 150 \mathrm{~m}$ a.s.1., 5151; veg.: Pinus, Picea, Betula, Pteropsida, Marchantiopsida, Musci.

42. Suchá Bělá, pond. Wetland above the pond in the vicinity of Hřensko, ca. $50^{\circ} 53^{\prime} \mathrm{N}, 14^{\circ} 15^{\prime} \mathrm{E}, 190 \mathrm{~m}$ a.s.l., 5151; veg.: Picea, Pinus, Alnus, Betula, Carex, Juncus, Caltha.

43. Šluknov (literature record, Ježek 1985), 5059'N, 14²6' E, 347 m a.s.l., 4952. 
44. Šluknov-údolí (railway station), small dry forest pond in a valley, ca. $50^{\circ} 59^{\prime} \mathrm{N}, 14^{\circ} 28^{\prime} \mathrm{E}, 389 \mathrm{~m}$ a.s.1., 4952 ; veg.: Quercus, Picea, Pinus, Alnus, Betula, Iris, Scirpus, Lysimachia, Solanum.

45. Tokáń, vicinity of a pension, rocky slopes, swamps ESE, ca. $50^{\circ} 52^{\prime} \mathrm{N}, 14^{\circ} 24^{\prime} \mathrm{E}, 417 \mathrm{~m}$ a.s.1., 5152; veg.: Betula, Pinus, Picea, Rubus, Carex, Juncus, Pteropsida, Musci.

46. Eustach. U svatého Eustacha, $2.7 \mathrm{~km}$ west of the village Doubice, ca. $50^{\circ} 53^{\prime} \mathrm{N}, 14^{\circ} 25^{\prime} \mathrm{E}, 460$ m.a.s.1., 5152; subcontinental pine oak forests growing on top of sandstone rocks, which merge on the edges of rocks into relict boreocontinental pine forests (pine oak); veg.: Pinus, Betula, Quercus, Sorbus, Frangula, Vaccinium, Calluna and Avenella.

47. Vlčí Hora - Zahrady, „Na Ranči“, small pond, meadow spring, ca. 5055'N, 14²7’E, 485 m a.s.1., 5052; veg.: Salix, Sorbus, Typha, Scirpus, Urtica, Carex, Caltha.

48. Vlčí potok Brook, SE of Brtníky, ca. 50 50 56'N, $14^{\circ} 27^{\prime} \mathrm{E}$, 380-395 m a.s.l., 5052, ash-alder meadow, stream alder; veg.: Alnus, Acer, Picea, Prunus, Sambucus; Athyrium, Calamagrostis, Carex, Chrysosplenium, Equisetum, Festuca, Filipendula, Geum, Impatiens, Juncus, Lysimachia, Rubus, Scirpus, Senecio, Stachys, Stellaria, Urtica.

49. Všemily env. Srbská Kamenice, swamps by the Kamenice River, brook, ca. 5050'N, 14²2'E, $213 \mathrm{~m}$ a.s.l., 5152; veg.: Picea, Alnus, Frangula, Scirpus, Caltha, Marchantiopsida.

50. Vysoká Lípa, water reservoir, pastures, arable land, ca. $50^{\circ} 51^{\prime} \mathrm{N}, 14^{\circ} 20^{\prime} \mathrm{E}, 351 \mathrm{~m}$ a.s.l., 5152; veg.: Picea, Pinus, Betula, Tilia, Quercus, Salix, Alnus, Rubus, Polygonum, Carex, Juncus, Poaceae.

51. Zadní Doubice (Křinice river), abandoned former settlement, hilly rocky region, ca. $50^{\circ} 55^{\prime} \mathrm{N}, 14^{\circ} 24^{\prime} \mathrm{E}$, 285 m a.s.l., 5052; veg.: Picea, Pinus, Salix, Alnus, Rubus, Urtica, Calamagrostis, Carex, Juncus.

52. Zadní Jetřichovice - small pond and Křinice River, ca. $50^{\circ} 53^{\prime} \mathrm{N}, 14^{\circ} 22^{\prime} \mathrm{E}, 240-255$ m a.s.l.; 5152 . Forest-free enclave (abandoned meadows) inside otherwise extensive forests, along the outcrops of rocks; veg.: Picea, Alnus (old trees); Agrostis, Calamagrostis, Carex, Cirsium, Festuca, Glyceria, Chaerophyllum, Juncus, Lysimachia, Molinia, Phalaris, Scirpus, Stellaria, Sphagnum, Urtica.

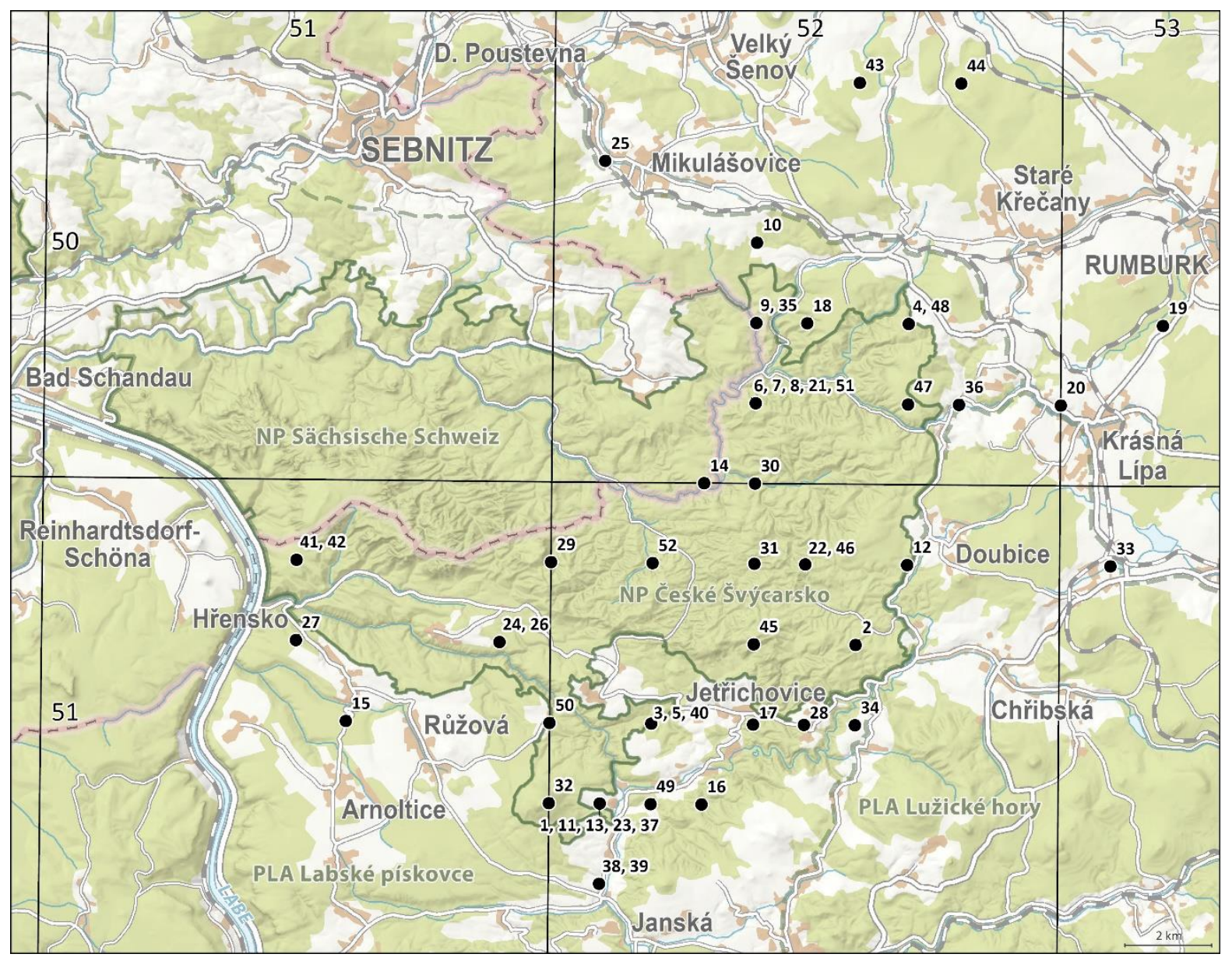

Map 1: Northern Hercynicum with marked localities 1-52 (relief view), prepared by O. Holešinský (Source of background data: SNPČŠ, LfULG, ČÚZK, GeoSN, GeoBasis-DE / BKG, IPF TUD). 


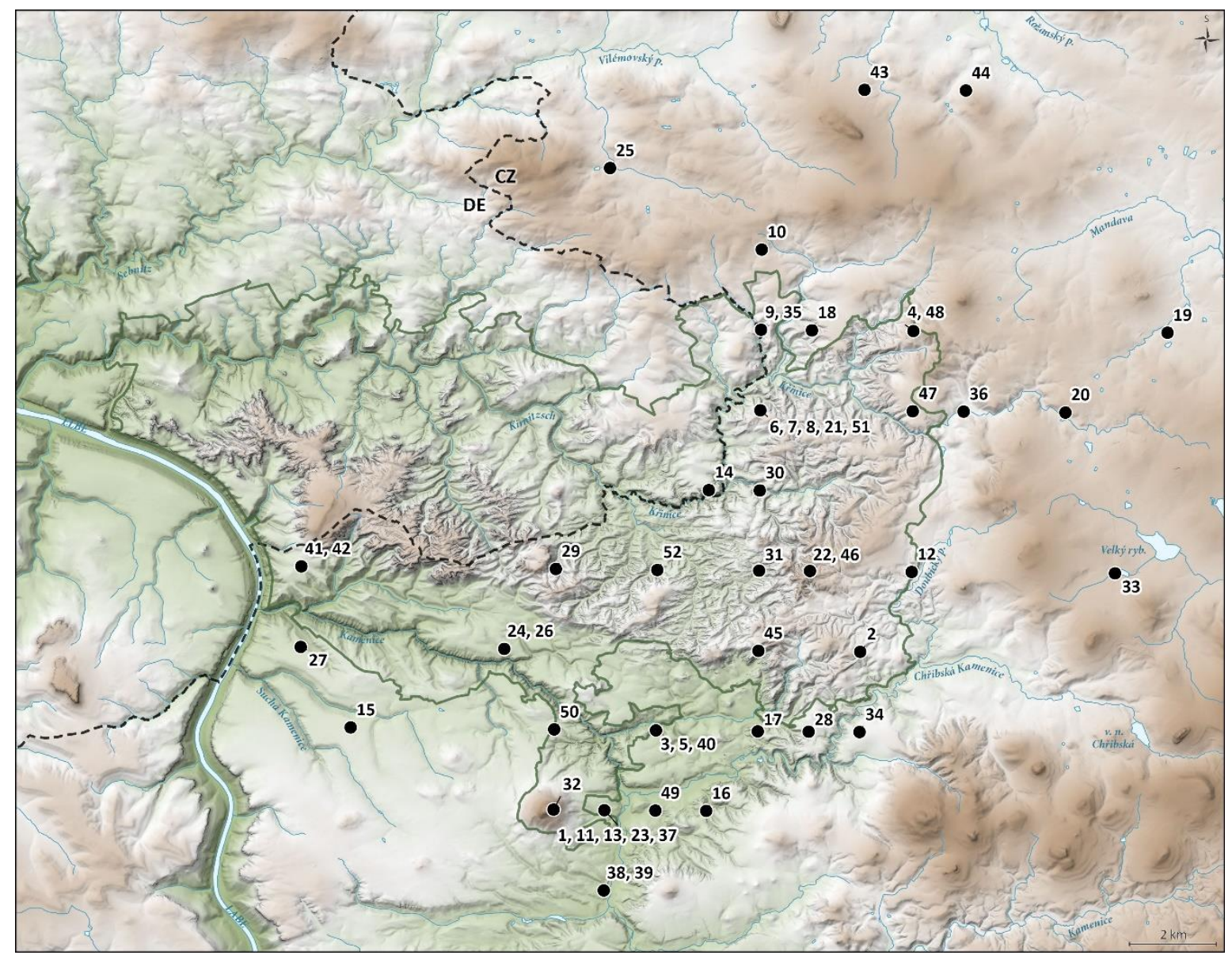

Map 2: Colored shaded digital relief model of Bohemian - Sächsische / Saxon Switzerland with indicative marking of the borders of the national parks České Švýcarsko and Sächsische Schweiz / Saxon Switzerland, and with marking of localities 1-52, prepared by O. Holešinský

(Source of background data: SNPČŠ, LfULG, ČÚZK, GeoSN, IPF TUD).

\section{Results}

We analysed material obtained from 2004 to 2010 from 52 sites located in the northern Hercynian Mountains and adjacent localities (Czech Republic). Based on 1167 slides from this material, we identified 88 species/subspecies belonging to three subfamilies. Below we present a list of recorded species, together with the information on the material examined and notes.

\section{A LIST OF SPECIES}

Sycorax silacea Haliday in Curtis, 1839

Material examined: Nad Edmundovou soutěskou Gulch (27), §̂, 23.-27.6.2008, Trýzna + Ježek leg., YPT, INS

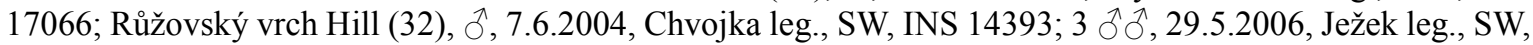
INS 15185, 15109 and 15218; ภ, 26.5.2008, Ježek leg., SW, INS 17041; Suchá Bělá, pond (42), đ̂, 15.6.2005, MT, INS 14288.

Comments: European species of spring areas, sporadically common. Distributed in West Europe including British Isles, regions of Central Europe, boreal ecoregion (Scandinavia), Apennines and Balkan Peninsula. Not recorded on Iberian Peninsula and in Eastern Europe. An overview of the detailed distribution is given in Ježek et al. (2020).

\section{Sycorax tonnoiri Jung, 1954 - CR}

Material examined: Mlýny (26), đ̂, 15.7.2004, Chvojka leg., SW, INS 14363; Nad Edmundovou soutěskou Gulch (27), ô, 23.-27.6.2008, Trýzna + Ježek leg., YPT, INS 17065.

Comments: European species (Central Europe and Balkan) - see Ježek et al. (2020).

The assessment of the current conservation status (Ježek 2005): CR. Larvae are found primarily in forest spring areas. 
Trichomyia urbica Haliday in Curtis, 1839 - CR

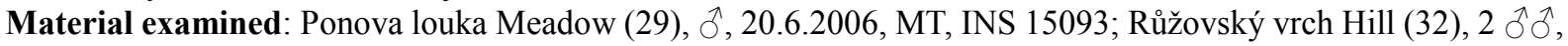
30.6.2010, MT, INS 19278 a 19464; Zadní Jetřichovice (52), +, 25.6.2007, MT, INS 16517.

Comments: Registered in 16 European countries, not known from Iberian Peninsula and Apennines, known recently as well from Transcaucasia (Ježek et al. 2021), not common, xylophagous larvae are found in rotting wood of fallen trees. Critically endangered in CZ (CR).

Katamormia bezzii (Salamanna, 1983) - NS

Material examined: Křinice River (21), ô, 10.6.2010, MT, INS 19437.

Comments: A very rare species, known only from a single locality so far, described and well illustrated by Salamanna, who revised 2 males and 2 females (Italy, Sondro, 11.5.1903, M. Bezzi leg., deposited in MSNM) incorrectly determined by Tonnoir as Pericoma palposa Tonn. As new for the fauna of the Czech Republic (Silesia) was published by Kroča \& Ježek (2019), the first finding outside of Italy. České Švýcarsko NP is second northest known locality, species new for Bohemia, nationaly scarce (NS).

Katamormia strobli Ježek, 1986 - VU

Material examined: Meanders of Chřibská Kamenice River (23), đ̂, 15.6.2005, MT, INS 14331.

Comments: Very rare species known only from Austria and Czech Republic (Phragmitetum often shown as habitat of this species), additionaly collected as well in Finland (Salmela et al. 2014). Apparently important species for nature conservation, vulnerable in $\mathrm{CZ}$ (VU).

Oomormia andrenipes (Strobl, 1910) - CR

Material examined: between Vysoká Lípa and Jetřichovice (5), đ̂, 8.6.2004, Ježek leg., SW, INS 14396; Bílý potok Brook (6), đ̂, 17.7.2006, MT, INS 15099; Křinice River (21), ô, 10.6.2010, MT, INS 19427; Pryskyřičný důl Valley (30), Ô, 2.6.2008, MT, INS 17086; Vysoká Lípa (50), Ô, 8.6.2004, Ježek leg., SW, INS 14395; Zadní Doubice (Křinice River) (51), Ô, 17.6.2009, INS 18296; Zadní Jetřichovice (52), Ô, 25.6.2007, MT, INS 16405.

Comments: Rather rare species registered from Great Britain, Czech Republic, Slovakia, Austria, Slovenia and Bosnia (Ježek 1984, 1994, Ježek \& Omelková 2007). Critically endangered in CZ (CR).

Jungiella (Jungiella) hassiaca Wagner, 1993 - NS

Published records: Brtnický most Bridge (7) and Křinice River (21) (Ježek 2009a).

Comments: Extremely rare species known only from the original description of a single male (holotype) from Hesse, additional specimens were published from Bohemia and Moravia (Ježek et al. 2005, Ježek 2009a). Apparently important species for the nature conservation, a monitoring will be badly needed (NS).

Jungiella (Jungiella) hygrophila Ježek, 1987

Material examined: Dolský mlýn Mill (11), ô, 15.6.2005, MT, INS 14306; Doubice (12), đ̂, 9.6.2004, Ježek leg., SW, INS 13056; Pryskyřičný důl Valley (30), ô, 2.6.2008, MT, INS 17092; Rynartice - Weidlichova kaple Chapel (34), ô, 9.6.2004, Ježek leg., SW, INS 14352; Suchá Bělá Brook (42), đ̂, 15.6.2005, MT, INS 14296.

Comments: European species (knowledge are limited so far), not common, registered in Belgium, Bulgaria, Czech Republic, Poland, Slovakia, Ukraine - see Ježek et al. (2020). Sometimes in an association with J. soleata (Walker, 1856) and J. valachica (Vaillant, 1963).

Jungiella (Jungiella) septentrionalis Krek, 1979 - NS

Published record: Růžovský vrch Hill (32) (Ježek 2009a).

Comments: Extremely rare species known from the original description (2 males from Bosnia and Herzegovina). New localities are recently known from Bohemia and Moravia (Ježek 2009a). Apparently important species for the nature conservation, a monitoring is needed (NS).

Jungiella (Jungiella) soleata (Walker, 1856)

Material examined: Brtníky env. Mikulášovice, Brtnický potok Brook (9), đo, 15.6.2005, Ježek leg. SW, INS 15159; Doubice (12), đૈ, 9.6.2004, Ježek leg., SW, INS 13059; Jetřichovice, Jetřichovická Bělá Brook (17), Ô, 7.6.2004, Ježek leg., SW, INS 13086; Krásná Lípa, brook (19), đ̂, 17.6.2005, Ježek leg., SW, INS 15180;

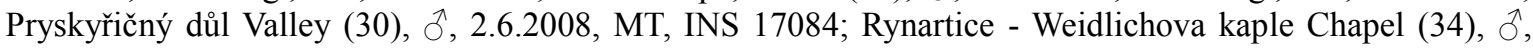
9.6.2004, Ježek leg., SW, INS 14353; Srbská Kamenice (western part) (38), đ̂, 30.5.2006, Ježek leg., SW, INS 15227.

Comments: Common species distributed almost throughout Europe including British Islands, however, not recorded from the boreal ecoregion (Scandinavia) and Iberian Peninsula. Known as well from northern Iran. Occurence: lowlands, hills and mountainous biotopes. Detailed information see Ježek et al. (2020). 
Jungiella (Jungiella) valachica (Vaillant, 1963)

Material examined: between Vlčí Hora and Brtníky (4), đ̂, 22.6.2004, Ježek leg., SW, INS 13079; Brtníky env. Mikulášovice, Brtnický potok Brook (9), ô, 15.6.2005, Ježek leg., SW, INS 15175; Dolský mlýn Mill (11), ô, 15.6.2005, MT, INS 14319; Doubice (12), ô, 9.6.2004, Ježek leg., SW, INS 13053; Krásná Lípa, pond (20), đ, 14.6.2005, Ježek leg., SW, INS 14378; Meanders of Chřibská Kamenice River (23), đ̂, 15.6.2005, MT, INS

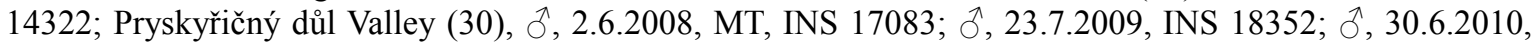
MT, INS 19360; Zadní Doubice (Křinice River) (51), đ̂, 17.6.2009, INS 18306; ðૈ, 30.6. 2010, MT, INS 19415.

Comments: Sporadically common, lowlands and hills. An overview of the detailed distribution is given in Ježek et al. (2020).

Jungiella (Psychocha) acuminata (Szabó, 1960)

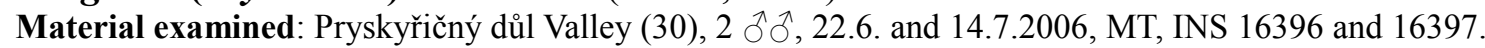

Comments: European mainly steppe species (known recently only from seven countries) connected by his development only hardly and surprissingly with Pryskyřičný důl Valley (a deep canyon-shaped inverse gorge); distribution of the species see e.g. Ježek et al. (2018).

Jungiella (Psychocha) laminata (Szabó, 1960) - CR

Material examined: Pryskyřičný důl Valley (30), ô, 22.6.2006, MT, INS 16436.

Comments: Very rare xerophilous Central European species (registered in six countries - see e.g. Oboňa \& Ježek 2014). The finding in the mentioned inverse gulch was probably processed by aerial drifts over hilly combs from suitable biotopes out of the studied area, where the development of larvae is possible. Endangered in $\mathrm{CZ}$ (CR).

Jungiella (Psychocha) procera Krek, 1971

Material examined: Suchá Bělá, pond (42), ô, 15.6.2005, MT, INS 14301.

Comments: Rather rare hardly known species, common only in places. Habitats: banks of brooks mainly of steppe dried localities in Bosnia and Herzegovina, Bulgaria, Czech Republic and Serbia (Krek 1999, Ježek et al. 2020).

Lepiseodina rothschildi (Eaton, 1912) - NS

Material examined: Mlýny (26), đ̂, 16.5.2007, MT, INS 16352; Prysky̌ričný důl Valley - peat bogs (31), స̂, 25.8.2009, INS 18408; Růžovský vrch Hill (32), ô, 20.9.2005, MT, INS 16489; đ̂, 30.6.2010, MT, INS 19469.

Comments: Rather rare European species, known from British Islands, countries along the Northern Sea, Czech Republic and Italy. Not recorded from Iberian Peninsula, boreal ecoregion (Scandinavia) and Balkan. Information in details see e.g. Ježek (2004a) and Ježek et al. (2005). Apparently important species for the nature conservation, a monitoring is needed (NS).

Panimerus denticulatus Krek, 1971

Material examined: Rybniště env. Krásná Lípa (33), đ̂, 21.6.2004, Ježek leg. SW, INS 15200.

Comments: A locally common euryvalent European species, inhabiting various types of aquatic biotopes: springs, brooks, rivers, ponds, wet meadows and pastures from lowlands to mountains, collected in 12 countries. Known additionally as well from Transcaucasia (Azerbaijan and Georgia) - Ježek et al. (2020, 2021).

\section{Panimerus falcariformis Wagner, 1977 - NS}

Published record: Meanders of Chřibská Kamenice River (23) (Ježek 2006a).

Comments: Very rare species known only from two males from Germany, collected almost before three decades. Ježek (2006a) published this species from the border between České Švýcarsko National Park and Labské pískovce Protected Landscape Area as new for the Czech Republic. Apparently important species for the nature conservation, a monitoring is needed (NS).

\section{Panimerus notabilis (Eaton, 1893)}

Material examined: Brtnický potok Brook env. Brtníky (8), ô, 1.6.2009, INS 18395.

Comments: Common European species recorded from countries along the North Sea (including British Islands), distributed in Scandinavia, Central Europe, Poland and Balkan. The species has not been taken so far from Iberian Peninsula and European part of Russia, however, recorded from northern Iran (Kandavan). It is a first moth fly colonizer of fresh furrows (maximally two years old) in Central Europe - traces of big stowing opencast machines filled by rain water, with first invasive dump water plants as Typha (Ježek et al. 2019).

\section{Parajungiella ellisi (Withers, 1987) - CR}

Material examined: Jetř̌ichovice, Jetř̌ichovická Bělá Brook (17), đ̂, 7.6.2004, Ježek leg., SW, INS 13090; Sněžná nr. Krásná Lípa (brook) (36) đે, 21.6.2004, Ježek leg., SW, INS 14361. 
Comments: Rather rare European and West-siberian species, described not long ago, occuring from lowlands to mountains. Habitats: peripheries of ponds, marshes and inundated meadows. Geographical distribution: Austria, Great Britain, Ireland, Czech Republic, Slovakia and Russia (Siberia) - Ježek et al. (2019). Critically endangered species in CZ (CR).

Parajungiella longicornis (Tonnoir, 1919)

Material examined: Jetřichovice, Jetřichovická Bělá Brook (17), ô, 7.6.2004, Ježek leg., SW, INS 13088; Kopec nr. Brtníky (18), đ̃, 15.6.2005, Ježek leg., SW, INS 16464; Krásná Lípa, brook (19), ô, 17.6.2005, Ježek leg., SW, INS 15178; Krásná Lípa, pond (20), đ̄, 14.6.2005, Ježek leg., SW, INS 14375; Sněžná nr. Krásná Lípa

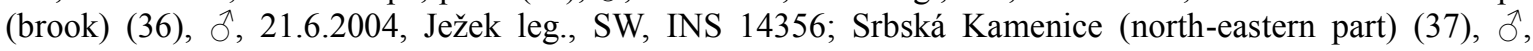
30.5.2006, Ježek leg., SW, INS 15231.

Comments: European and West-Siberian species, very common, occuring in 17 countries from lowlands to mountains: countries along Northern Sea including British Islands, Scandinavia, Central and South Europe and Novosibirsk region in Russia. Not recorded from Iberian Peninsula so far. An overview of the detailed distribution is given e.g. by Ježek et al. (2020).

\section{Parajungiella prikryli Ježek, 1999 - VU}

Material examined: Srbská Kamenice (north-eastern part) (37), ઊ̂, 30.5.2006, Ježek leg., INS 15235.

Comments: Apparently a rare central European species, known only from the Czech Republic and Slovakia (Ježek 1999, Ježek \& Omelková 2012, Oboňa \& Ježek 2014).

\section{Parajungiella pseudolongicornis (Wagner, 1975) - CR}

Material examined: Jetřichovice, Jetřichovická Bělá Brook (17), Õ, 7.6.2004, Ježek leg., SW, INS 13089; Kopec nr. Brtníky (18), đ̃, 15.6.2005, Ježek leg., SW, INS 16488; Krásná Lípa, pond (20), Ô, 14.6.2005, Ježek leg., SW, INS 14374; Sněžná nr. Krásná Lípa (brook) (36), đ̃, 21.6.2004, Ježek leg., SW, INS 14357.

Comments: Rare species recorded only from Great Britain, Ireland, Austria, Czech Republic, Slovakia, Serbia, Bosnia and Herzegovina; critically endangered in CZ (CR) - Ježek \& Omelková (2012).

\section{Parajungiella serbica (Krek, 1985) - CR}

Material examined: Jetřichovice, Jetřichovická Bělá Brook (17), đ̂, 7.6.2004, Ježek leg., SW, INS 13082; Krásná Lípa pond (20), ふ̂, 14.6.2005, Ježek leg., SW, INS 14376.

Comments: Rather rare species, occuring sporadically in Central Europe, Balkan and Transcaucasia. Habitats: inundated meadows, swamped pastures, small brooks and lakes with a salinity. Endangered in CZ (CR). An overview of the detailed distribution is given by Ježek et al. (2020).

Paramormia (Duckhousiella) ustulata (Walker, 1856)

Material examined: Pryskyřičný důl Valley (30), ㅇ, 29.8.2008, MT, INS 17180; Suchá Bělá, pond (42), 은 15.6.2005, MT, INS 14284; Zadní Jetřichovice (52), , 21.9.2009, MT, INS 18422.

Comments: A widespread species currently known to occur in the Holarctic Region (incl. newly Transcaucasia). Larvae are registered in substrates of quite different extreme chemical composition: mineral and calcareous thermal springs, salt works, saltboils, soaks of open-cast coal mines and dumps, poultry farms etc. (Ježek \& Yağci 2005, Ježek et al. 2020, 2021).

\section{Paramormia (Paramormia) polyascoidea (Krek, 1971)}

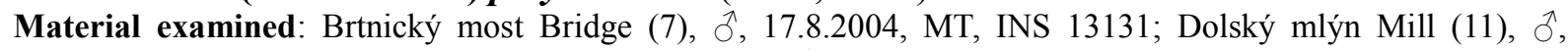
15.6.2005, MT, INS 14313; Kopec nr. Brtníky (18), đ̃, 15.6.2005, Ježek leg., SW, INS 16487; Křinice River

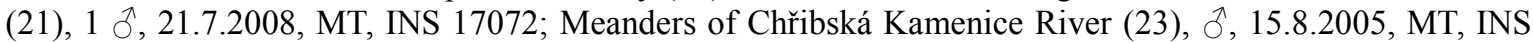
16486; Ponova louka Meadow (29), đ̃, 20.6.2006, MT, INS 15094; Pryskyřičný důl Valley (30), đ̃, 2.6.2008, MT, INS 17096; Suchá Bělá, pond (42), 2 ổ, 22.5. and 15.6.2005, MT, INS 14287 and 15118; Zadní Doubice (Křinice River) (51), $2 \widehat{\jmath} \widehat{\jmath}, 20.7 .2009$ and 10.6.2010, MT, INS INS 18344 and 19287; Zadní Jetřichovice (52), $2 \widehat{\jmath} \hat{\jmath}, 1.6$. and 21.9.2009, MT, INS 18311 and 18433.

Comments: European and West-Siberian not rare species, ranging from lowlands to mountains (Austria, Belgium, Bosnia, Bulgaria, Czech Republic, Estonia, Finland, Germany, Poland and Russia - Novosibirsk region; the species has been taken as well in Transcaucasia) - Ježek et al. (2020).

Peripsychoda auriculata (Haliday in Curtis, 1839)

Material examined: Jetřichovice, Jetřichovická Bělá Brook (17), ô, 7.6.2004, Ježek leg., SW, INS 13084; Kopec nr. Brtníky (18), ô, 15.6.2005, Ježek leg., SW, INS 16406; Limberk (22), đ̃, 14.7.2006, VÚLHM leg., MT, INS 16407; Meanders of Chřibská Kamenice River (23), 2 đ̃ đ̃, 24.6.2004 and 15.7.2005, Ježek leg., SW, MT, INS 13108 and 15129; Mikulášovice (25), đ̃, 15.6.2005, Ježek leg., SW, INS 15189; Pryskyřičný důl Valley (30), đ̃, 30.6.2010, MT, INS 19357; Růžovský vrch Hill (32), đ̃, 30.6.2010, MT, INS 19465; Rybniště env. Krásná Lípa (33), ô, 21.6.2004, Ježek leg., SW, INS 15202; Severák (35), 2 đ̊đ̃, 24.6.2008, Ježek leg., SW, INS 17004 and 17019; Sněžná nr. Krásná Lípa (brook) (36), đ̃, 21.6.2004, Ježek leg., SW, INS 14360; Tokáň (45), đ̃, 16.7.2004, Chvojka leg., SW, INS 13097; Vlčí potok Brook (48), ô, 1.6.2009, MT, INS 18274. 
Comments: European and Transcaucasian species (penetrating to Abkhazia and Georgia), very common, ranging from lowlands to hilly regions. The species has not yet been recorded from Iberian Peninsula, in contrast to Balkan, Appenine Mountains and Siberia (Novosibirsk region). Occassionally numerous in Malaise and yellow pan traps. An overview of the detailed distribution is given by Ježek et al. (2020) and Morelli \& Biscaccianti (2021).

Psycmera integella (Jung, 1956) - CR

Material examined: Brtníky env. Mikulášovice, Brtnický potok Brook (9), ふૈ, 15.6.2005, Ježek leg., SW, INS 15177; Doubice (12), đ̃, 9.6.2004, Ježek leg., SW, INS 13058; Krásná Lípa, pond (20), đ̃, 14.6.2005, Ježek leg., SW, INS 14377; Rybniště env. Krásná Lípa (33), ô, 21.6.2004, Ježek leg., SW, INS 15199; Srbská Kamenice (north-eastern part) (37), đ̃, 30.5.2006, Ježek leg., SW, INS 15230; Srbská Kamenice (western part) (38), ठ̂, 30.5.2006, Ježek leg., SW, INS 15225.

Comments: European and West-Siberian species, not frequent, ranging from lowlands to hilly regions, from Central Europe penetrates to Balkan and Novosibirsk region in Russia - Ježek et al. (2019). Critically endangered in $\mathrm{CZ}(\mathrm{CR})$.

Seoda carthusiana (Vaillant, 1972)

Material examined: Jetřichovice, Jetřichovická Bělá Brook (17), đ̃, 7.6.2004, Ježek leg., SW, INS 13091; Krásná Lípa, brook (19), ô, 17.6.2005, Ježek leg., SW, INS 15179; Ponova louka Meadow (29), đ̃, 20.6.2006, MT, INS 15097; Růžovský vrch Hill (32), ô, 7.6.2004, Chvojka leg., SW, INS 14391; ふ̄, 26.5.2008, Ježek leg., SW, INS 17012; Rynartice - Weidlichova kaple Chapel (34), ô, 9.6.2004, Ježek leg., SW, INS 14348.

Comments: European species, common in places, ranging from lowlands to mountains, known from Czech Republic, France, Germany, Poland, Slovakia and Slovenia (Ježek et al. 2019).

Seoda gressica (Vaillant, 1972)

Material examined: between Jetřichovice and Starý mlýn Mill (3), đ̂, 8.6.2004, Ježek leg., SW, INS 13149; Brtnický potok Brook env. Brtníky (8), ô, 1.6.2009, INS 18387; Meanders of Chřibská Kamenice River (23), đ̃, 15.6.2005, MT, INS 14337; Pryskyřičný důl Valley (30), ô, 2.6.2008, MT, INS 17104; Růžovský vrch Hill (32), ô, 7.6.2004, Chvojka leg., SW, INS 14392; $2 \hat{\jmath} \widehat{\jmath}, 17.5$. and 30.6.2010, MT, INS 19386 and 19477; Rynartice - Weidlichova kaple Chapel (34), ô, 9.6.2004, Ježek leg., SW, INS 14343; Srbská Kamenice (northeastern part) (37), đ̂, 30.5.2006, Ježek leg., SW, INS 15232; Suchá Bělá, pond (42), ô, 15.6.2005, MT, INS 14297; Zadní Jetřichovice (52), ô, 10.6.2010, MT, INS 19446.

Comments: European species, sporadically common, ranging from low landscape elevation to mountain combs, known from Austria, Czech Republic, France and Poland (Ježek \& Omelková 2012). A species locally abundant penetrates to the same habitats as $S$. carthusiana.

\section{Seoda labeculosa (Eaton, 1893) - EN}

Published records: between Jetřichovice and Starý mlýn Mill (3), between Vlčí Hora and Brtníky (4), Jetřichovice, Jetřichovická Bělá Brook (17), Vlčí Hora - Zahrady (47) (Ježek 2006a).

Material examined: Brtníky env. Mikulášovice, Brtnický potok Brook (9), ô, 15.6.2005, Ježek leg., SW, INS 15171; Dolský mlýn Mill (11), đ̃, 15.6.2005, MT, INS 14305; Krásná Lípa, brook (19), đ̃, 17.6.2005, Ježek leg., SW, INS 15196; Krásná Lípa, pond (20), đ̃, 14.6.2005, Ježek leg., SW, INS 14373; Meanders of Chřibská Kamenice River (23), đ̂, 15.6.2005, MT, INS 14330; Mikulášovice - upper station (25), đે, 15.6.2005, Ježek leg., SW, INS 15190; Nad Edmundovou soutěskou Gulch (27), ふૈ, 28.5.2008, Ježek leg., SW, INS 17010; Ponova louka Meadow (29), đ̃, 20.6.2006, MT, INS 15086; Pryskyřičný důl Valley (30), ô, 22.6.2006, VÚLHM leg., MT, INS 16437; Růžovský vrch Hill (32), ô, 7.6.2004, Chvojka leg., SW, INS 14390; Severák (35), đ̃, 2.7.2008, ET, INS 17119; Srbská Kamenice (western part) (38), đ̃, 30.5.2006, Ježek leg., SW, INS 15208; Vlčí potok Brook (48), ô, 17.7.2006, MT, INS 15072; ô, 1.6.2009, INS 18279; Zadní Doubice (Křinice River) (51), ふ̃, 30.6.2010, MT, INS 19419; Zadní Jetřichovice (52), ふૈ, 25.6.2007, MT, INS 16438.

Comments: Species known only from Europe: Belgium, Czech Republic, Denmark, France, Great Britain and Ireland; some findings from České Švýcarsko NP were published as new faunistic records for Bohemia. Habitats: winding flows, spring areas and swamps. Some detailed information see Ježek (2003, 2006a) and Ježek et al. (2019), endangered in CZ (EN).

Feuerborniella obscura (Tonnoir, 1919)

Material examined: Bílý potok Brook (6), ๆ, 21.7. 2008, MT, INS 17059; Hadí pramen Spring (14), ๆ, 30.6.2010, ET, INS 19284; Křinice River (21), o, 21.7.2008, MT, INS 17079; Mikulášovice (25), ㅇ, 15.6.2005, Ježek leg., SW, INS 15188; Pryskyřičný důl Valley (30), , 2.6.2008, MT, INS 17109; ㅇ, 30.6.2010, MT, INS 19363; Vlčí potok Brook (48), Õ, + , 17.7. and 20.8.2006, MT, INS 15071 and 16474; + , 1.6.2009, INS 18288.

Comments: Common European species, known from 17 countries and a wide spectrum of altitudes, from Central Europe penetrates along the Atlantic coast to England, southern border of its distribution is limited by Apennines and Balkan. Newly was this species recorded in Transcaucasia. Larvae occur in spring areas on wet surfaces of boulders and in wet moss. An overview of the distribution is given by Ježek et al. $(2020,2021)$. 
Philosepedon humerale (Meigen, 1818)

Material examined: Rybniště env. Krásná Lípa (33), đ̃, 21.6.2004, Ježek leg., SW, INS 15217; Srbská Kamenice (north-eastern part) (37), đ̃, 30.5.2006, Ježek leg., SW, INS 15228; Zadní Jetřichovice (52), ô, 8.6.2004, Ježek leg., SW, INS 13106.

Comments: Very common European species registered almost in 30 countries; the species penetrates to Northern (Algeria) and Western Africa (Mauretania), some Islands of Atlantic Ocean (Azores, Canary Islands), Indian Ocean (Seychelles) and Mediterranean Sea (Cyprus); the elevation of localities is not important, adults are collected frequently by light traps, larvae are conchibiont (Ježek et al. 2020).

Threticus lucifugus (Walker, 1856)

Published records: Šluknov (43) - Ježek (1985).

Material examined: Bílý potok Brook (6), ô, 21.7. 2008, MT, INS 17057; Vlčí potok Brook (48), đ̂, 21.9.2009, INS 18475; Všemily env. Srbská Kamenice (49), đ̃, 30.5.2006, Ježek leg., SW, INS 15222; Zadní Doubice

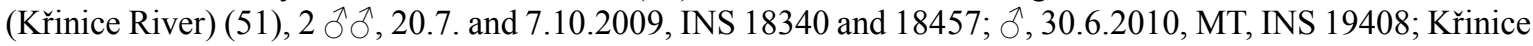
River - Zadní Jetřichovice (52), ô, 30.6.2010, MT, INS 19320.

Comments: Common European species, registered from 10 countries so far (Ježek et al. 2019). Larvae occur in slow flows on boulders with wet moss.

Threticus silvaticus Ježek, 1985 - VU

Material examined: Brtnický potok Brook env. Brtníky (8), đ̃, 1.6.2009, INS 18388; Meanders of Chřibská Kamenice River (23), ô, 15.7.2005, MT, INS 15147; Zadní Doubice (Křinice River) (51), ô, 20.7.2009, INS 18334.

Comments: Central European rare species, known only from Czech Republic and Slovakia (Oboňa \& Ježek 2014, Ježek et al. 2019). Collected in dunging spring areas, marches and near drains. Vulnerable in CZ (VU).

Trichopsychoda hirtella (Tonnoir, 1919)

Material examined: between Jetřichovice and Starý mlýn Mill (3), đ̊, 8.6.2004, Ježek leg., SW, INS 13148; Bílý potok Brook (6), + , 21.7. 2008, MT, INS 17051; Brtnický most Bridge (7), + , 17.8.2004, MT, INS 13121; Dolský mlýn Mill (11), ō, 2 우, 26.7. and 17.8. 2004, 15.6.2005, MT, INS 13135, 14310 and 15150; Křinice River (21), ô, 21.7.2008, MT, INS 17073; Meanders of Chřibská Kamenice River (23), 4 q , 1 15.6., 15.7., 15.8. and 20.9.2005, MT, INS 14327, 15140, 16363 a 16444; Ponova louka Meadow (29), , 20.6.2006, MT, INS 15104; Pryskyřičný důl Valley (30), 2 우, 22.6. and 14.7.2006, VÚLHM leg., MT, INS 16443 and 16454; 2 우우, 1 Jे, 2.6., 21.7. and 29.8.2008, MT, INS 17097, 17176 and 17209; + , 30.6.2010, MT, INS 19367; Růžovský vrch Hill (32), +, 20.9.2005, MT, INS 16453; Srbská Kamenice (western part) (38), đ̂, 30.5.2006, Ježek leg., SW, INS 15223; Suchá Bělá Brook (41), +, 23.-27.6.2008, SC, Ježek + Trýzna leg., INS 18482; Suchá Bělá, pond (42), + , 20.9.2005, MT, INS 16383; Vlčí potok Brook (48), ô, †, 17.7. and 20.8.2006, MT, INS 15065 and 16452; $\hat{O}, 2$ 우, 1.6., 20.7. and 21.9.2009, INS 18287, 18376 and 18469; Zadní Doubice (Křinice River) (51), 3 + , 17.6., 20.7. and 7.10.2009, INS 18295, 18328 and 18445; $q, 30.6 .2010$, MT, INS 19405; Zadní Jetřichovice (52), 2 q + , 17.8.2004 and 25.6.2007, MT, INS 13061 and 16442; + , 1.6.2009, INS 18322; 2 ふ઼ે, 10. and 30.6. 2010, MT, INS 19428 and 19313.

Comments: European species, collected in 12 countries (Ježek et al. 2020), southern border of its distribution is limited by Apennines and Balkan. Larvae occur in rotting plants and fruits as well far from water (Vaillant 1974). Adults are occassionally numerous in Malaise and yellow pan traps.

Apsycha pusilla (Tonnoir, 1922) - NS

Published record: Srbská Kamenice (a farm of cattle) (39) - Ježek (2009a)

Comments: Holarctic species mainly found in cow-sheds (coprophilous or coprobiontic species), therefore overlooked, not common. Known from Austria, Belgium, Great Britain, Italy, Lithuania and Poland; there are more records from USA (Ježek 2007, Ježek et al. 2018). Nationally scarce in CZ (NS), from Silesia published by Kroča \& Ježek (2019).

Chodopsycha buxtoni (Withers, 1988) - NS

Published records: Zadní Jetřichovice (52) (Ježek 2006a).

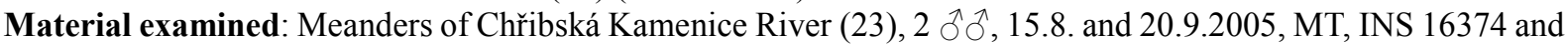

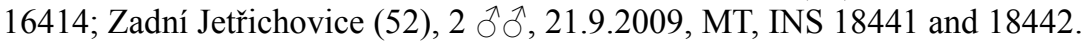

Comments: Species known only from Great Britain, Czech Republic and Slovakia, larvae are mycobiont (Ježek 2003, 2006a). Male from Zadní Jetřichovice (52) represented first locality in Bohemia. Nationally scarce (NS). 
Chodopsycha lobata (Tonnoir, 1940)

Material examined: Bílý potok Brook (6), q, 17.7.2006, MT, INS 15098; , 21.7.2008, MT, INS 17046; Brtnický most Bridge (7), o, 17.8.2004, MT, INS 13129; Dolský mlýn Mill (11), + , 17.8.2004, MT, INS 15165; Hadí pramen Spring (14), ô, 8.-12.9.2008, Ježek + Trýzna leg., YPT, INS 17112; Křinice River (21), + , 21.7.2008, MT, INS 17082; Limberk (22), q, 14.7.2006, VÚLHM leg., MT, INS 16460; Meanders of Chřibská Kamenice River (23), 2 우, 15.8. and 20.9.2005, MT, INS 16360 and 16458; Nad Edmundovou soutěskou Gulch (27), ð, 23.-27.6.2008, Ježek + Trýzna leg., YPT, INS 17062; Ponova louka Meadow (29), đ, 20.6.2006, MT, INS 15105; Pryskyřičný důl Valley (30), 2 우, 22.6. and 14.7.2006, VÚLHM leg., MT, INS 16459 and 16461; 3 우, 2.6., 21.7. and 29.8.2008, MT, INS 17087, 17171 and 17213; $q, 23.7 .2009$, INS 18355; 2 q, , 10. and 30.6.2010, MT, INS 19456 and 19372; Pryskyřičný důl Valley - peat bogs (31), 2 q + , 25.8. and 7.10.2009, INS 18406 and 18418; Růžovský vrch Hill (32), +, 20.9.2005, MT, INS 16457; Suchá Bělá, pond (42), đ̃, +, 15.6. and 20.9.2005, MT, INS 14283 and 16384; Eustach (46), 3 우, 2.6., 1.7. and 21.7.2008, MT, INS 17024, 17147 and 17165; Vlčí potok Brook (48), 2 \&, 17.7. and 20.8.2006, MT, INS 15069 and 16456; 2 우, 20.7. and 21.9.2009, INS 18372 and 18470; Zadní Doubice (Křinice River) (51), 3 \& $\odot, 17.6 ., 20.7$. and 7.10.2009, INS 18301, 18329 and 18462; 2 우, 10. and 30.6.2010, MT, INS 19296 and 19418; Zadní Jetřichovice (52), $\widehat{\partial},+$, 17.8.2004 and 25.6.2007, MT, INS 13064 and 16462; the same, small pond, $0,21.9 .2009$, INS 18434; o, ,, 10 . and 30.6.2010, MT, INS 19322 and 19444.

Comments: Common European species, known from 21 countries (lowlands, hills and mountains), Transcaucasian sites represent Abkhazia and Georgia, larvae are mycobiont. Adults are occassionally numerous in Malaise - and yellow pan traps. An overview of the detailed distribution is given by Ježek et al. (2020, 2021).

\section{Copropsychoda brevicornis (Tonnoir, 1940)}

Material examined: Bílý potok Brook (6), Ô, 21.7. 2008, MT, INS 17050; Brtnický most Bridge (7), + 17.8.2004, MT, INS 13117; Brtnický potok Brook env. Brtníky (8), ふૈ, 1.6.2009, INS 18394; Meanders of Chřibská Kamenice River (23), 3 우, 15.7., 15.8. and 20.9.2005, MT, INS 15155, 16378 and 16412; Mlýny (26), ㅇ, 16.5.2007, MT, INS 16341; Ponova louka Meadow (29), 2 q , , 29.5. and 20.6.2006, MT, INS 15092 and 16410; Pryskyřičný důl Valley (30), 2 ડ̄ô, 21.7. and 29.8.2008, MT, INS 17178 and 17210; Pryskyřičný důl Valley - peat bogs (31), ๆ, 25.8.2009, INS 18409; Suchá Bělá, pond (42), ô, o , 22.5. and 20.9.2005, MT, INS 15125 and 16387; Eustach (46), +, 12.5.08, MT, INS 17127; Vlčí potok Brook (48), 2 ふ઼̊, 17.7. and

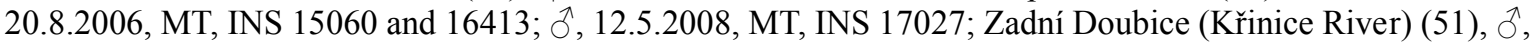
+ , 20.7. and 7.10.2009, INS 18333 and 18459; Zadní Jetřichovice (52), 2 우, 25.6. and 17.8.2004, MT, INS 13072 and 16411.

Comments: Palaearctic species, registered in 15 countries, common. The developing of larvae was observed in pasturelands polluted by excrements of cattle. Adults are always frequent in Malaise and yellow pan traps. A detailed distribution is given by Ježek \& Yağci (2005) and Ježek et al. (2020, 2021).

\section{Logima albipennis (Zetterstedt, 1850)}

Material examined: between Jetřichovice and Starý mlýn Mill (3), + , 8.6.2004, Ježek leg., SW, INS 13146; Bílý potok Brook (6), + , 21.7. 2008, MT, INS 17055; Brtnický most Bridge (7), + , 17.8.2004, MT, INS 13116; Brtnický potok Brook env. Brtníky (8), †, 1.6.2009, INS 18397; Dolský mlýn Mill (11), 4 q $q, 26.7 ., 17.8$. and 25.10.2004, 15.6.2005, MT, INS 13132, 14303, 15166 and 16401; Křinice River (21), ㅇ, 21.7.2008, MT, INS 17075; Meanders of Chřibská Kamenice River (23), 4 우, 15.6., 15.7., 15.8. and 20.9.2005, MT, INS 14336, 15146, 16372 and 16398; Mlýny (26), , 16.5.2007, MT, INS 16358; Ponova louka Meadow (29), + , 20.6.2006, MT, INS 15107; Pryskyřičný důl Valley (30), 3 우, 12.5., 2.6. and 29.8.2008, MT, INS 17110, 17188 and 17198; q, 23.7.2009, MT, INS 18363; + , 30.6.2010, MT, INS 19368; Pryskyřičný důl Valley - peat bogs (31), q, 7.10.2009, MT, INS 18419; Růžovský vrch Hill (32), + , 17.5.2010, MT, INS 19392; Severák (35), +, 2.7.2008, ET, INS 17118; Sněžná nr. Krásná Lípa (brook) (36), †, 21.6.2004, Ježek leg., SW, INS 14355; Suchá Bělá, pond (42), 3 우, 22.5., 15.6. and 20.9.2005, MT, INS 14300, 15122 and 16395; Tokán̆ (45), ㅇ, 16.7.2004, Chvojka leg., SW, INS 13099; Vlčí potok Brook (48), 2 우, 17.7. and 20.8.2006, MT, INS 15062 and 16399; 3 우, 1.6., 20.7. and 21.9.2009, MT, INS 18290, 18379 and 18477; + , 17.5.2010, MT, INS 19342; Zadní Doubice (Křinice River) (51), 3 o $ᄋ$, 17.6., 20.7. and 7.10.2009, MT, INS 18305, 18341 and 18455; 2 우, 10. and 30.6.2010, MT, INS 19298 and 19413; Zadní Jetřichovice (52), 3 q $ᄋ$, 8.6. and 17.8.2004, 25.6.2007, MT, INS 13070, 13105 and 16400; ㅇ, 10.6.2010, MT, INS 19439; ㅇ, 21.9.2009, MT, INS 18438.

Comments: Cosmopolitan species, eurybiont, very common: Ježek et al. (2019, 2020, 2021). Adults are occassionally numerous in all occasionaly used traps, in light traps are attracted besides as well by blue shine. Larvae are saprophagous. 
Logima erminea (Eaton, 1893)

Material examined: Brtnický most Bridge (7), , 17.8.2004, MT, INS 13120; Hadí pramen Spring (14), ㅇ , 8.12.9.2008, Ježek + Trýzna leg., YPT, INS 17113; Křinice River (21), †, 21.7.2008, MT, INS 17080; Meanders of Chřibská Kamenice River (23), + , 15.7.2005, MT, INS 15154; Pryskyřičný důl Valley (30), +, 23.7.2009, MT, INS 18359; ㅇ, 30.6.2010, MT, INS 19361; Severák (35), ㅇ, 2.7.2008, ET, INS 17121; Zadní Doubice (Křinice River) (51), +, 7.10.2009, INS 18461; ô, 30.6.2010, MT, INS 19426; Zadní Jetřichovice (52), , 17.8.2004, MT, INS 13066; خ̊, 21.9.2009, MT, INS 18430.

Comments: Palaearctic species, common, registered in 21 European countries, however, as well in Transcaucasia (Abkhazia), Tchaj-wan, Japan and North Africa (Algeria) - see Ježek et al. (2019, 2020). Included frequently in samples from Malaise traps (installed in different altitudes), however, always only in a small number; registered as well in caves, but bionomy is generally a little known.

\section{Logima satchelli (Quate, 1955)}

Material examined: Bílý potok Brook (6), + , 21.7. 2008, MT, INS 17056; Brtnický most Bridge (7), q, 17.8.2004, MT, INS 13114; Brtnický potok Brook env. Brtníky (8), o , 1.6.2009, INS 18396; Dolský mlýn Mill (11), 3 우, 26.7. and 17.8.2004, 15.6.2005, MT, INS 13133, 14317 and 15167; Křinice River (21), $\hat{\jmath}$, 21.7.2008, MT, INS 17076; Limberk (22), क , 14.7.2006, VÚLHM leg., MT, INS 16493; Meanders of Chřibská Kamenice River (23), 3 웅, 15.7., 15.8. and 20.9.2005, INS 15143, 16373 and 16496; Mlýny (26), $\widehat{o}$, 16.5.2007, MT, INS 16359; Nad Edmundovou soutěskou Gulch (27), ㅇ, 23.-27.6.2008, Trýzna + Ježek leg., YPT, INS 17060; Ponova louka Meadow (29), ð̇, + , 29.5. and 20.6.2006, MT, INS 15106 and 16492; Pryskyřričný důl Valley (30), 2 우, 22.6. and 14.7.2006, VúLHM leg., MT, INS 16491 and 16494; $\widehat{\jmath}, 3$ 우, 12.5., 2.6., 21.7. and 29.8.2008, MT, INS 17105, 17175, 17197 and 17205; ㅇ, 23.7.2009, MT, INS 18364; $\hat{\jmath}$, + , 10. and 30.6.2010, MT, INS 19369 and 19455; Pryskyřičný důl Valley - peat bogs (31), 2 우, 25.8. and 7.10.2009, INS 18410 and 18420; Růžovský vrch Hill (32), ô, 15.6. and 20.9.2005, MT, INS 14349 and 16498; J, \&, 17.5. and 30.6.2010, MT, INS 19394 and 19475; Srbská Kamenice (western part) (38), + , 30.5.2006, SW, INS 15226; Suchá Bẻlá, pond (42), ô, 2 웅, 22.5., 15.6. and 20.9.2005, MT, INS 14294, 15119 and 16380; Eustach (46), $3 \widehat{\partial} \widehat{\partial}, 2$ 우, 12.5., 2.6., 1.7. and 21.7.2008, MT, INS 17021, 17124, 17144, 17153 and 17161; Vlčí potok Brook (48), 2 + $ᄋ$, 17.7. and 20.8.2006, MT, INS 15061 and 16495; ㅇ, 12.5.2008, MT, INS 17028; 2 우, 1.6. and 20.7.2009, INS 18289 and 18380; ${ }^{\wedge}$, 17.5.2010, MT, INS 19345; Zadní Doubice (Křinice River) (51), 2 우, 10. and 30.6.2010, MT, INS 19297 and 19425; 3 웅 17.6., 20.7 and 7.10.2009, MT, INS 18304, 18343 and 18464; Zadní Jetřichovice (52), 2 우, 17.8.2004 and 25.6.2007, MT, INS 13063 and 16497; 2 q $9,1.6$. and 21.9.2009, INS 18325 and 18439 .

Comments: Holarctic species (15 Europen countries, Turkey, Transcaucasia - Azerbaijan, Canada, USA) - see e. g. Ježek et al. (2020), common, eurybiont, collected in all suitable altitudes: Malaise, rotate, emergent, light inclusive of blue shine and yellow pan traps (with salt solution).

\section{Logima sigma (Kincaid, 1899)}

Material examined: Pryskyřičný důl Valley (30), đ̂, 2.6.2008, MT, INS 17098.

Comments: Probably cosmopolitan species, however data from some zoogeographical regions still missing. Registered from Europe, Transcaucasia (Azerbaijan), North Amerika (USA), South Amerika (Chile), Australia and New Zealand; some Australian and Subantarctic Islands, Polynesia, Micronesia, Bahamas and isles in South Atlantic. An overview of the detailed distribution is given by Ježek et al. (2021).

\section{Logima zetterstedti Ježek, 1983}

Material examined: between Jetřichovice and Starý mlýn Mill (3), †, 8.6.2004, Ježek leg., SW, INS 13147; Bílý potok Brook (6), ๆ, 17.7.2006, MT, INS 15113; Brtnický most Bridge (7), †, 17.8.2004, MT, INS 13115; Dolský mlýn Mill (11), 3 웅, 26.7., 17.8. and 25.10.2004, MT, INS 13144, 15160 and 16518; Doubice (12), ㅇ, 9.6.2004, Ježek leg., SW, INS 13054; Meanders of Chřibská Kamenice River (23), ㅇ, 20.9.2005, MT, INS 16371; Mlýny (26), + , 16.5.2007, MT, INS 16356; Pryskyřičný důl Valley (30), +, 14.7.2006, VÚLHM leg., MT, INS 16519; Růžovský vrch Hill (32), , , 15.6.2005, MT, INS 14350; Rynartice - Weidlichova kaple Chapel (34), + , 9.6.2004, Ježek leg., SW, INS 14346; Suchá Bělá, pond (42), + , 15.6.2005, MT, INS 14299; Zadní Doubice (Křinice River) (51), + , 30.6.2010, MT, INS 19421; Zadní Jetřichovice (52), + , 17.8.2004, MT, INS 13071.

Comments: European and West-Siberian species (Novosibirsk region), known from 20 European countries, Turkey, Atlantic Ocean (Azores, Canary Islands), South Pacific Ocean (Fiji) and the boundary between the East China Sea and the Philippine Sea (Ryukyu Islands) - Ježek et al. (2020, 2021), very common in places from wide range of altitudes. Numerous in all occasionally used traps. Larvae are saprobiont. Adults are sometimes closed in sheaths of Arum maculatum L. (Araceae) and cause pollination. 
Psycha grisescens (Tonnoir, 1922)

Material examined: Bílý potok Brook (6), , 17.7.2006, MT, INS 15114; †, 21.7. 2008, MT, INS 17054; Brtnický most Bridge (7), ô,, , 8.6. and 17.8.2004, MT, INS 13127 and 16346; Brtnický potok Brook env. Brtníky (8), ㅇ, 1.6.2009, MT, INS 18392; Dolský mlýn Mill (11), 3 우 , 17.8. and 25.10.2004, 15.6.2005, MT, INS 14315, 15162 and 16451; Křinice River (21), Ô, 21.7.2008, MT, INS 17077; Meanders of Chřibská Kamenice River (23), 3 우 , 15.6., 15.7. and 20.9.2005, MT, INS 14338, 15145 and 16361; Mlýny (26), ㅇ, 16.5.2007, MT, INS 16353; Ponova louka Meadow (29), $\widehat{O}$, ,, , 29.5. and 20.6.2006, MT, INS 15102 and 16450; Pryskyřičný důl

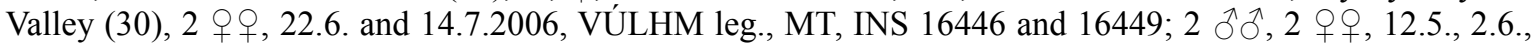
21.7. and 29.8.2008, MT, INS 17091, 17184, 17190 and 17215; 우, 23.7.2009, INS 18360; 2 우, 10. and 30.6.2010, MT, INS 19365 and 19451; Pryskyřičný důl Valley - peat bogs (31), +, 25.8.2009, INS 18413; Rủžovský vrch Hill (32), $\hat{\partial}$, ㅇ, 15.6. and 20.9.2005, MT, INS 14340 and 16448; $\hat{\partial}$, + , 17.5. and 30.6.2010,

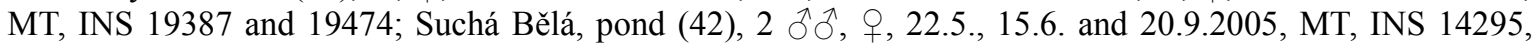
15124 and 16382; Eustach (46), 5 우, 12.5., 2.6., 1.7. and 21.7.2008, MT, INS 17023, 17130, 17149, 17157 and 17166; Vlčí potok Brook (48), +, 17.7.2006, MT, INS 15068; ㅇ, 12.5.2008, MT, INS 17034; 3 우, 1.6., 20.7. and 21.9.2009, MT, INS 18285, 18373 and 18471; + , 17.5.2010, MT, INS 19341; Zadní Doubice (Křinice River) (51), 3 웅, 17.6., 20.7. and 7.10.2009, MT, INS 18300, 18336 and 18447; 2 웅, 10. and 30.6.2010, MT, INS 19290 and 19416; 2 + $q, 17.8 .2004$ and 25.6.2007, MT, INS 13073 and 16447; $\hat{\alpha},+$, 1.6. and 21.9.2009, MT, INS 18324 and 18437; ô,, , 10. and 30.6.2010, MT, INS 19317 and 19438.

Comments: Collected in 21 European countries, very common, inhabiting zone from British Isles to Lithuania and Central Anatolia, Transcaucasia (Azerbaijan), the northern border lies in boreal ecoregion (Scandinavia) and southern limits occur in North Africa (Algeria, Morocco, Tunisia), Mediterranean Sea (Mallorca) and North Atlantic archipelago (Faroe Islands) - Ježek et al. (2020, 2021). Collected often not only by sweep netting, however, all occasionally used traps. Larvae are saprobiont.

\section{Psychoda crassipennis Tonnoir, 1940}

Material examined: Meanders of Chřibská Kamenice River (23), ô, 15.6.2005, MT, INS 14334; Růžovský vrch Hill (32), + , 17.5.2010, MT, INS 19393; Vlčí potok Brook (48), +, 17.7.2006, MT, INS 15066; Zadní Doubice (Křinice River) (51), 2 우, 10. and 30.6.2010, MT, INS 19292 and 19424; Zadní Jetřichovice (52), ㅇ, 10.6.2010, MT, INS 19435.

Comments: European species, not common, from British Islands penetrates along the Atlantic coast to Scandinavia, registered as well in Czech Republic - Ježek (2009a), Ježek et al. (2019). Larvae occur in litoral zone of polluted water reservoirs and in swampy areas. Females were recorded in sheads of Arum cylindraceum Gasp. (Araceae) as pollinators.

\section{Psychoda phalaenoides (Linnaeus, 1758)}

Material examined: Bílý potok Brook (6), †, 17.7.2006, MT, INS 15117; †, 21.7. 2008, MT, INS 17048; Brtnický most Bridge (7), 2 우, 8.6. and 17.8.2004, MT, INS 13124 and 16348; Brtnický potok Brook env. Brtníky (8), ㅇ 1.6.2009, INS 18386; Dolský mlýn Mill (11), 4 우, 26.7., 17.8. and 25.10.2004, 15.6.2005, MT, INS 13138, 14308, 15149 and 16480; Křinice River (21), + , 21.7.2008, MT, INS 17069; Meanders of Chřibská Kamenice River (23), $\partial^{\lambda}, 3$ 우, 15.6., 15.7., 15.8. and 20.9.2005, MT, INS 14335, 15142, 16351 and 16482; Mikulášovice - upper station (25), ô, 15.6.2005, Ježek leg., SW, INS 15193; Mlýny (26), ㅇ, 16.5.2007, MT, INS 16354;

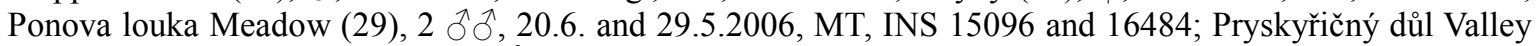
(30), $\hat{o}$, , + , 22.6. and 14.7.2006, VÚLHM leg., MT, INS 16478 and 16485; $\hat{\jmath}, 3$ q 9 , 12.5., 2.6., 21.7. and 29.8.2008, MT, INS 17099, 17172, 17191 and 17211; 2 + $ᄋ, 15 .-19.6 .2009$, sticky cartons, Ježek + Trýzna leg.,

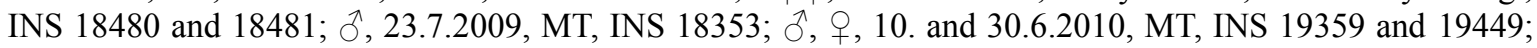
Prysky̌ričný důl Valley - peat bogs (31), 2 우, 25.8. and 7.10.2009, INS 18403 and 18416; Růžovský vrch Hill (32), 2 웅, 15.6. and 20.9.2005, MT, INS 14341 and 16481; + , 26.5.2008, Ježek leg., SW, INS 17042; đ, o, 17.5. and 30.6.2010, MT, INS 19377 and 19472; Rybniště env. Krásná Lípa (33), đે, 21.6.2004, Ježek leg., SW, INS 15198; Srbská Kamenice (western part) (38), đ̂, 30.5.2006, Ježek leg., SW, INS 15224; Suchá Bělá, pond (42), $2 \widehat{\partial} \partial^{\lambda}$,, , 22.5., 15.6. and 20.9.2005, MT, INS 14293, 15136 and 16388; Eustach (46), 4 우, 12.5., 2.6. and 1.7.2008, MT, INS 17131, 17150, 17158 and 17164; Vlčí potok Brook (48), $2 \delta^{\lambda} \delta^{\lambda}, 17.7$. and 20.8.2006, MT, INS 15064 and 16483; + , 12.5.2008, MT, INS 17036; $\hat{\jmath}$, ㅇ, 1.6. and 20.7.2009, INS 18283 and 18366; ㅇ, 17.5.2010, MT, INS 19331; Zadní Doubice (Křinice River) (51), 3 우우 17.6., 20.7. and 7.10.2009, MT, INS 18293, 18326 and 18456; 2 우, 10. and 30.6.2010, MT, INS 19291 and 19407; Zadní Jetřichovice (52), 2 우, 17.8.2004 and 25.6.2007, MT, INS 13077 and 16479; $\widehat{\partial}$, ㅇ, 1.6. and 21.9.2009, MT, INS 18320 and $18435 ; 2 \hat{\jmath} \partial^{\lambda}, 10$. and 30.6.2010, MT, INS 19310 and 19432.

Comments: Holarctic species - collected in 30 European countries, as well as in Transcaucasia (Georgia), from Atlantic Ocean we must mention Canary Islands, from Mediterranean Sea Balearic Islands and Sardinia; North Africa (Algeria), Tchaj-wan, Japan, New Zealand, Alaska and Canada - see e. g. Wagner (2018) and Ježek et al. (2020). Polyvoltine species (several generations annualy), very common, known from all suitable altitudes, in traps, adults are sometimes in sheaths of Arum maculatum L. and cause pollination. Larvae are saprobiont. 
Psychoda uniformata Haseman, 1907

Material examined: Dolský mlýn Mill (11), + , 25.10. 2004, MT, INS 16516; Meanders of Chřibská Kamenice River (23), 2 qq, 15.7. and 20.9.2005, MT, INS 15144 and 16377; Pryskyřičný důl Valley (30), q, 29.8.2008, MT, INS 17177; Suchá Bělá, pond (42), 2 우, 22.5. and 15.6.2005, MT, INS 14285 and 15120; Zadní Doubice (Křinice River) (51), o, 7.10.2009, MT, INS 18454.

Comments: Holarctic species, sporadically common, recorded in seven Europen countries (Ježek et al. 2020), penetrates to Turkey, Transcaucasia (Armenia, Azerbaijan), North Africa (Morocco), Israel, Mongolia, Iran and USA. Larvae are saprophagous and develop besides as well in animal sheds, stables and dog kennels etc.

\section{Psychodocha cinerea (Banks, 1894)}

Material examined: Bílý potok Brook (6), , 17.7.2006, MT, INS 15116; q, 21.7. 2008, MT, INS 17052; Brtnický most Bridge (7), + , 17.8.2004, MT, INS 13130; Brtnický potok Brook env. Brtníky (8), + , 1.6.2009, INS 18390; Dolský mlýn Mill (11), 4 우, 26.7., 17.8. and 25.10.2004, 15.6.2005, MT, INS 13140, 14302, 15152 and 16420; Hadí pramen Spring (14), q, 8.-12.9.2008, YPT, Ježek + Trýzna leg., INS 17115; q, 17.5.2010, ET, INS 19398; Janov (15), +, 17.5.2010, ET, INS 19396; Kopec nr. Brtníky (18), +, 15.6.2005, Ježek leg., SW, INS 16422; Křinice River (21), †, 21.7.2008, MT, INS 17081; Meanders of Chřibská Kamenice River (23), 4 우, 15.6., 15.7., 15.8. and 20.9.2005, MT, INS 14325, 15132, 16367 and 16416; Mikulášovice - upper station (25), + , 15.6.2005, Ježek leg., SW, INS 15207; Mlýny (26), q, 16.5.2007, MT, INS 16342; Pryskyřičný důl Valley (30), 2 우, 22.6. and 14.7.2006, VÚLHM leg., MT, INS 16417 and 16419; 4 q $q, 12.5 ., 2.6 ., 21.7$. and 29.8.2008, MT, INS 17095, 17182, 17189 and 17203; ô, o, 23.7. and 25.8.2009, MT, INS 18349 and 18479; ㅇ, 30.6.2010, MT, INS 19371; Pryskyřičný důl Valley - peat bogs (31), , 30.4.2009, ET, INS 18478; 2 우, 25.8. and 7.10.2009, INS 18407 and 18415; Růžovský vrch Hill (32), , 20.9.2005, MT, INS 16418; 우, 17.5.2010, MT, INS 19381; Rynartice, Weidlichova kaple Chapel (34), ô, 9.6.2004, Ježek leg., SW, INS 14345; Severák (35), 2 우, 2.7. and 12.8.2008, ET, INS 17120 and 17139; Suchá Bělá, pond (42), 3 q, , 22.5., 15.6. and 20.9.2005, MT, INS 14290, 15137 and 16392; Eustach (46), ô, o, 12.5. and 1.7.2008, MT, INS 17126 and 17162; Vlčí potok Brook (48), + , 17.7.2006, MT, INS 15074; ㅇ, 12.5.2008, MT, INS 17035; 3 q + , 1.6., 20.7. and 21.9.2009, MT, INS 18281, 18368 and 18466; $q$, 17.5.2010, MT, INS 19328; Zadní Doubice (Křinice River) (51), 3 우, 17.6., 20.7. and 7.10.2009, MT, INS 18303, 18330 and 18453; 2 우, 10. and 30.6.2010, MT, INS 19294 and 19409; Zadní Jetřichovice (52), 2 우, 17.8.2004 and 25.6.2007, MT, INS 13062 and 16421; ㅇ, 21.9.2009, MT, INS 18425; 2 우, 10. and 30.6.2010, MT, INS 19323 and 19441.

Comments: Cosmopolitan species, very common, occuring in a wide range of altitudes. Occassionally numerous in all used traps. Larvae are saprophagous and often found in polluted WC. Known geographical distribution see e.g. Ježek \& Yağci (2005), Afzan \& Belquat (2016) and Ježek et al. (2020, 2021).

\section{Psychodocha gemina (Eaton, 1904)}

Material examined: Bílý potok Brook (6), , 17.7.2006, MT, INS 15115; ㅇ, 21.7.2008, MT, INS 17044; Brtnický most Bridge (7), ๆ, 17.8.2004, MT, INS 13122; Brtnický potok Brook env. Brtníky (8), †, 1.6.2009, INS 18381; Dolský mlýn Mill (11), 4 q , , 26.7., 17.8. and 25.10.2004, 15.6.2005, MT, INS 13141, 14320, 15161 and 16433; Hadí pramen Spring (14), + , 8.-12.9.2008, Ježek + Trýzna leg., YPT, INS 17116; 2 q,+ 10. and 30.6.2010, ET, INS 19283 and 19347; Janov (15), ô, 30.6.2010, ET, INS 19354; Křinice River (21), + 21.7.2008, MT, INS 17068; Limberk (22), o, 14.7.2006, VÚLHM leg., MT, INS 16445; Meanders of Chřibská Kamenice River (23), 4 o $\circ$, 15.6., 15.7., 15.8. and 20.9.2005, MT, INS 14323, 15141, 16368 and 16432; Mlýny (26), ô, 16.5.2007, MT, INS 16357; Nad Edmundovou soutěskou Gulch (27), +, 23.-27.6.2008, Trýzna + Ježek leg., YPT, INS 17064; Ponova louka Meadow (29), 2 우, 29.5. and 20.6.2006, MT, INS 15088 and

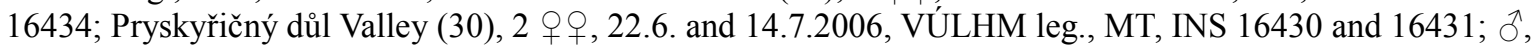
3 우, 12.5., 2.6., 21.7. and 29.8.2008, MT, INS 17085, 17183, 17201 and 17214; 9 , 23.7.2009, MT, INS 18350; 2 우, 10. and 30.6.2010, MT, INS 19362 and 19457; Pryskyřičný důl Valley - peat bogs (31), 2 우, 25.8. and 7.10.2009, MT, INS 18401 and 18414; Růžovský vrch Hill (32), 2 q + , 15.6. and 20.9.2005, MT, INS 14339 and 16429; $\widehat{\partial},+$, 17.5. and 30.6.2010, MT, INS 19383 and 19471; Severák (35), ô, o, 22.7. and 12.8.2008, ET, INS 17137 and 17142; Suchá Bělá, pond (42), đ̃, 2 q q, 22.5., 15.6. and 20.9.2005, MT, INS 14289, 15135 and 16393; Eustach (46), 5 우, 12.5., 2.6., 1.7. and 21.7. 2008, MT, INS 17022, 17128, 17151, 17156 and 17169; Vlčí potok Brook (48), ô,,+17.7 . and 20.8.2006, MT, INS 15077 and 16427; $9,12.5 .2008$, MT, INS 17038; 3 우, 1.6., 20.7. and 21.9.2009, INS 18280, 18367 and 18468; + , 17.5.2010, MT, INS 19329; Zadní Doubice (Křinice River) (51), 3 우, 17.6., 20.7. and 7.10.2009, INS 18299, 18327 and 18444; 2 우, 10. and 30.6.2010, MT, INS 19289 and 19414; Zadní Jetřichovice (52), 2 q $ᄋ$, 17.8.2004 and 25.6.2007, MT, INS 13065 and 16428; 2 우, 1.6. and 21.9.2009, MT, INS 18317 and 18429; 2 $q_{+}, 10$. and 30.6.2010, MT, INS 19314 and 19430.

Comments: European species, common, known from 22 countries, however, penetrates as well to Transcaucasia (Abkhazia, Georgia), see Ježek et al. (2019, 2020, 2021). Collected often by all used traps from lowlands to mountains. Larvae are saprophagous, their development is sometimes adapted to nests of water birds. 
Psychodocha itoco (Tokunaga \& Komyo, 1955) - NS

Material examined: Brtnický potok Brook env. Brtníky (8), §̂, 1.6.2009, INS 18393; Dolský mlýn Mill (11), 2 $\widehat{\partial} \hat{\jmath}$, 26.7.2004 and 15.6.2005, MT, INS 13137 and 14304; Meanders of Chřibská Kamenice River (23), $3 \hat{\jmath} \widehat{\partial}$, 15.6., 15.8. and 20.9.2005, MT, INS 14328, 16375 and 16440; Pryskyřičný důl Valley (30), ô, 14.7.2006,

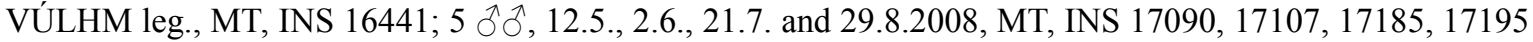
and 17207; Pryskyřičný důl Valley - peat bogs (31), đ̂, 25.8.2009, MT, INS 18411; Růžovský vrch Hill (32),

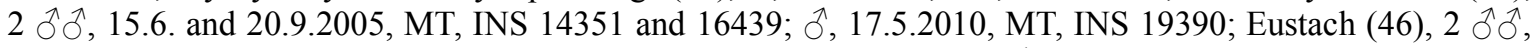
2.6. and 1.7.2008, MT, INS 17145 and 17160; Vlčí potok Brook (48), ô, 12.5.2008, MT, INS 17029; Zadní Doubice (Křinice River) (51), $2 \widehat{\delta} \widehat{\jmath}, 10$. and 30.6.2010, MT, INS 19299 and 19410; Zadní Jetřichovice (52), त, 10.6.2010, MT, INS 19445.

Comments: Probably Palaearctic species, however, so far known only from Japan (Ryukyu Island), Czech Republic and Finland (Ježek 2003, Salmela et al. 2014). Apparently important species for the nature conservation, a monitoring will be badly needed (NS).

Psychodula minuta (Banks, 1894)

Material examined: Bílý potok Brook (6), ๆ, 21.7.2008, MT, INS 17058; Brtnický most Bridge (7), ๆ, 17.8.2004, MT, INS 13118; Dolský mlýn Mill (11), 3 우, 26.7. and 17.8.2004, 15.6.2005, MT, INS 13134, 14321 and 15164; Hadí pramen Spring (14), ㅇ, 8.-12.9.2008, Ježek + Trýzna leg., YPT, INS 17114; Janov (15), §ิ, 30.6.2010, ET, INS 19353; Křinice River (21), ㅇ, 21.7.2008, MT, INS 17078; Meanders of Chřibská Kamenice River (23), 3 + , 15.6., 15.7. and 20.9.2005, MT, INS 14324, 15138 and 16379; Mlýny (26), †, 16.5.2007, MT, INS 16355; Ponova louka Meadow (29), + , 20.6.2006, MT, INS 15090; Pryskyřičný důl Valley (30), 2 q, 22.6. and 14.7.2006, VÚLHM leg., MT, INS 16467 and 16468; 3 우, 12.5., 2.6. and 29.8.2008, MT, INS 17089, 17179 and 17200; ㅇ, 23.7.2009, INS 18361; 2 우, 10. and 30.6.2010, MT, INS 19370 and 19450; Pryskyřičný důl Valley - peat bogs (31), †, 25.8.2009, MT, INS 18412; Rủžovský vrch Hill (32), o, 20.9.2005,

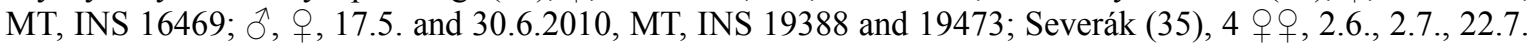
and 12.8.2008, ET, INS 17122, 17134, 17138 and 17143; Suchá Bělá, pond (42), 0 , 2 웅, 22.5., 15.6. and 20.9.2005, MT, INS 14282, 15123 and 16386; Eustach (46), $\delta$, 3 우우, 12.5., 2.6., 1.7.2008, MT, INS 17125,

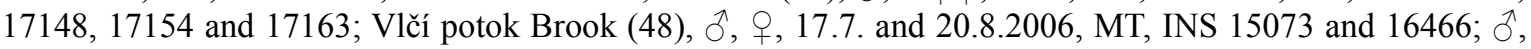
12.5.2008, MT, INS 17026; 2 우, 1.6. and 20.7.2009, INS 18286 and 18371; $0^{1}, 17.5 .2010$, MT, INS 19338; Zadní Doubice (Křinice River) (51); 2 우, 17.6. and 20.7.2009, INS 18302 and 18348; 2 우, 10. and 30.6.2010, MT, INS 19295 and 19412; Zadní Jetríichovice (52), 0 , ,, , 17.8.2004 and 25.6.2007, MT, INS 13067 and 16470; 2 우, 1.6. and 21.9.2009, MT, INS 18319 and 18426; $\widehat{O}$, 우 10 . and 30.6.2010, MT, INS 19316 and 19429.

Comments: Holarctic species, very common, ranging from lowlands to mountains, registered from 24 European countries, see e. g. Ježek et al. (2019, 2020), penetrates to Transcaucasia (Abkhazia) and Western Asia (Israel, Syria), from Mediterranean Sea are occupied Balearic Islands, Cyprus and Sardinia, from Atlantic Ocean Madeira, numerous collecting sites are known from Canada and USA. Occassionally numerous in all suitable traps. Larvae are saprobiont, known as well from caves (bat's guano).

\section{Psychomora mycophila (Vaillant, 1988)}

Material examined: Ponova louka Meadow (29), ô, 20.6.2006, MT, INS 15103; Pryskyřičný důl Valley (30), 2

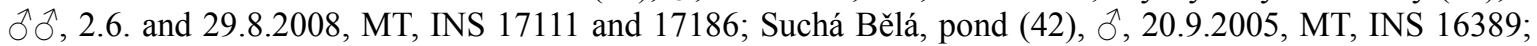
Eustach (46), ô, 2.6.2008, MT, INS 17146; Zadní Jetřichovice (52) đ̊, 21.9.2009, MT, INS 18440.

Comments: Rare European minute species (collected mainly by traps, hardly by sweep netting), inhabits localities at a wide range of altitudes. Distribution: Czech Republic, France, Slovakia, Slovenia, Switzerland, and Ukraine, new records are from Transcaucasia (Azerbaijan, Georgia) - see e.g. Ježek \& Omelková (2012), Ježek et al. $(2017,2019,2021)$. Larvae are mycobiont.

\section{Psychomora trinodulosa (Tonnoir, 1922)}

Material examined: Bílý potok Brook (6), ๆ, 21.7.2008, MT, INS 17047; Brtnický most Bridge (7), ô, 17.8.2004, MT, INS 13126; Brtnický potok Brook env. Brtníky (8), \&, 1.6.2009, INS 18391; Dolský mlýn Mill (11), ô, 2 우우, 26.7. and 17.8.2004, 15.6.2005, MT, INS 13142, 14314 and 15148; Křinice River (21), †, 21.7.2008, MT,

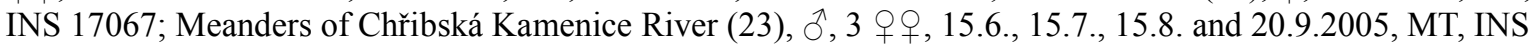
14326, 15157, 16364 and 16505; Nad Edmundovou soutěskou Gulch (27), , 23.-27.6.2008, Trýzna + Ježek

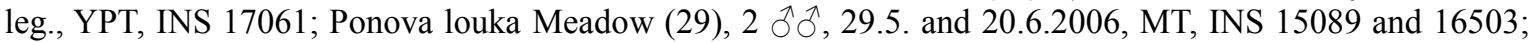
Pryskyřičný důl Valley (30), $\widehat{\partial}$, ,, 22.6. and 14.7.2006, VÚLHM leg., MT, INS 16504 and 16509; $\widehat{\partial}, 3$ 우, 12.5., 2.6., 21.7. and 29.8.2008, MT, INS 17106, 17170, 17199 and 17204; ㅇ, 23.7.2009, INS 18351; 2 우, 10. and 30.6.2010, MT, INS 19366 and 19452; Pryskyřičný důl Valley - peat bogs (31), ㅇ, 25.8.2009, MT, INS 18404; Růžovský vrch Hill (32), + , 20.9.2005, MT, INS 16506; §ૈ, 17.5.2010, MT, INS 19389; Suchá Bělá, pond (42), 2 우 , 15.6. and 20.9.2005, MT, INS 14291 and 16391; Eustach (46), 3 웅, 12.5., 1.7. and 21.7. 2008, MT, INS 17025, 17159 and 17167; Vlčí potok Brook (48), 2 우우, 17.7. and 20.8.2006, MT, INS 15067 and 16507; + , 12.5.2008, MT, INS 17037; $2 \delta^{\lambda} \delta^{\gamma}$, + , 1.6., 20.7. and 21.9.2009, INS 18282, 18377 and 
18474; ठิ, 17.5.2010, MT, INS 19332; Zadní Doubice (Křinice River) (51), ô, 2 q, 17.6., 20.7. and 7.10.2009, INS 18294, 18332 and 18446; 2 우, 10. and 30.6.2010, MT, INS 19288 and 19403; Zadní Jetřichovice (52), 2 우, 17.8.2004 and 25.6.2007, MT, INS 13076 and 16508; 2 우, 1.6. and 21.9.2009, INS 18318 and 18428; 2 우, 10. and 30.6.2010, MT, INS 19312 and 19442.

Comments: Holarctic species, very common, known from different altitudes, registered in 27 European countries, penetrates to Turkey (Anatolia) and Transcaucasia (Azerbaijan, Georgia), known from North Africa (Algeria), from the Mediterranean Sea (Sardinia), many sites are from USA. Occassionally numerous in all used traps. This species transfers larval stadiums of Rhabditis Duj. (Anguillulidae) and Gamasidae mites. An overview of the detailed distribution is given by Ježek et al. $(2019,2020,2021)$.

Tinearia alternata (Say, 1824)

Material examined: Bílý potok Brook (6), q, 17.7.2006, MT, INS 15101; Brtnický most Bridge (7), , , 17.8.2004, MT, INS 13123; Jetřichovice, Jetřichovická Bělá Brook (17), ô, 13.7.2004, Chvojka leg., SW, INS 14386; Meanders of Chřibská Kamenice River (23), , 20.9.2005, MT, INS 16369; Pryskyřičný důl Valley (30), , 14.7.2006, VÚLHM leg., MT, INS 16403; ㅇ, 29.8.2008, MT, INS 17174; †, 23.7.2009, INS 18358; Pryskyřičný důl Valley - peat bogs (31), +, 25.8.2009, MT, INS 18400; Růžovský vrch Hill (32), +, 20.9.2005, MT, INS 16390; Suchá Bělá, pond (42), 2 우, 15.6. and 20.9.2005, MT, INS 14286 and 16381; Vlčí potok Brook (48), 2 ổ, 17.7. and 20.8.2006, MT, INS 15075 and 16402; Zadní Doubice (Křinice River) (51), 2 우, 20.7. and 7.10. 2009, MT, INS 18346 and MT, 18450; 9 , 30.6.2010, MT, INS 19404; Zadní Jetřichovice (52), 2 우, 17.8.2004 and 25.6.2007, MT, INS 13069 and 16404; + , 21.9.2009, INS 18427.

Comments: Cosmopolitan species, very common, see Ježek et al. (2019, 2020). Occassionally numerous in Malaise -, light - and yellow pan traps. Larvae develop not only in rotten organic substrates and excrements, but live as well in madicolous habitats. In the case of mass occurrence the larvae block the function of oldfashioned biological filters of gravel sewage works.

Tinearia lativentris (Berdén, 1952)

Material examined: Dolský mlýn Mill (11), + , 26.7.2004, MT, INS 13143; Meanders of Chřibská Kamenice River (23), 2 q + , 15.7. and 20.9.2005, MT, INS 15156 and 16376; Pryskyřičný důl Valley (30),, , 14.7.2006, VÚLHM leg., MT, INS 16435; Suchá Bělá, pond (42), 9, 20.9.2005, MT, INS 16394; Vlčí potok Brook (48), $\hat{\sigma}$,,+ , 17.7. and 20.8.2006, MT, INS 15070 and 16455; 2 우, 20.7. and 21.9.2009, MT, INS 18378 and 18473; Zadní Doubice (Křinice River) (51), †, 7.10.2009, INS 18448; $9,30.6 .2010$, MT, INS 19406; Zadní Jetřichovice (52), + , 17.8.2004, MT, INS 13075; ㅇ, 21.9.2009, MT, INS 18424; ㅇ, 30.6.2010, MT, INS 19324.

Comments: Holarctic species, common in places, known from 20 European countries, penetrates to Turkey, Afghanistan and China. Some localities are in Western Asia (Israel, Syria), Balearic Islands and Sardinia in Mediterranean Sea, North Africa - Tunisia, numerous collecting sites are known from Canada, USA, Mexico and Nicaragua - Ježek et al. (2020). Light -, Malaise - and yellow pan traps are successful for the collecting of adults. Larvae are saprophagous.

Ypsydocha setigera (Tonnoir, 1922)

Material examined: Bílý potok Brook (6), q, 21.7.2008, MT, INS 17053; Brtnický most Bridge (7), 2 q, , 8.6. and 17.8.2004, MT, INS 13125 and 16347; Dolský mlýn Mill (11), 3 q + , 26.7. and 17.8.2004, 15.6.2005, MT, INS 13136, 14312 and 15151; Meanders of Chřibská Kamenice River (23), 4 q, , 15.6., 15.7., 15.8. and 20.9.2005, MT, INS 14329, 15139, 16362 and 16501; Mlýny (26), + , 16.5.2007, MT, INS 16340; Ponova louka Meadow (29), 2 우, 29.5. and 20.6.2006, MT, INS 15091 and 16499; Pryskyřičný důl Valley (30), ô, 3 웅, 2.6., 21.7. and 29.8.2008, MT, INS 17108, 17181, 17208 and 17212; + , 23.7.2009, MT, INS 18356; Pryskyřičný důl Valley - peat bogs (31), 2 우, 25.8. and 7.10.2009, MT, INS 18402 and 18417; Růžovský vrch Hill (32), , 20.9.2005, MT, INS 16502; $q, 17.5 .2010$, MT, INS 19375; Suchá Bělá, pond (42), 2 q + , 15.6. and 20.9.2005, MT, INS 14311 and 16385; Eustach (46), 3 q $q, 12.5$. and 1.7.2008, MT, INS 17129, 17155 and 17168; Vlčí potok Brook (48), ㅇ, 20.8.2006, MT, INS 16500; đิ, 12.5.2008, MT, INS 17033; ㅇ, 20.7.2009, MT, INS 18370; ㅇ, 17.5.2010, MT, INS 19340; Zadní Doubice (Křinice River) (51), 3 q , , 17.6., 20.7. and 7.10.2009, INS 18298, 18331 and 18460; 2 우, 10. and 30.6.2010, MT, INS 19293 and 19411; Zadní Jetřichovice (52), o, 17.8.2004, MT, INS 13074; ㅇ, 21.9.2009, MT, INS 18431; ㅇ, 30.6.2010, MT, INS 19321.

Comments: Holarctic species, very common in places. Distribution in Europe: Belgium, Czech Republic, Denmark, France, Germany, Great Britain, Ireland, Italy, Norway, Romania, Slovakia, Spain, Sweden; in addition Canada, USA, Japan - Ježek (2003) and Ježek et al. (2019). Occassionally numerous in all installed traps. This species transfers larval stadiums of Rhabditis Duj. (Anguillulidae) and Gamasidae mites. Larvae are saprobiont and develop besides in manure and liquid manure - often in remarkable altitudes (pastures, slope spring areas, avalanche scars). 
Berdeniella chvojkai Ježek, 1999 - VU

Material examined: between Dolský mlýn Mill and Královský smrk Spruce (1), đ̄, 7.6.2004, Ježek leg., SW, INS 13051; Brtnický potok Brook (8), ô, 1.6.2009, INS 18398; Pryskyřičný důl Valley (30), đ̂, 22.6.2006, VúLHM leg., MT, INS 16415; đ̂, 2.6.2008, MT, INS 17103; Zadní Doubice (Křinice River) (51), đ̂, 10.6.2010, MT, INS 19304; Zadní Jetřichovice (52), $2 \partial^{\lambda}$, , 8.6.2004 and 10.6.2010, Ježek leg., SW, MT, INS 13102 and 19443.

Comments: Probably Central European species, rare (Ježek 2003, 2005, Ježek et al. 2019), vulnerable (VU) in $\mathrm{CZ}$, collected only along streams and brooks in the area of Sokolov open - cast mines, Jeseníky PLA and České Švýcarsko NP so far.

Berdeniella illiesi Wagner, 1973 - NS

Published records: Brtnický potok Brook env. Brtníky (8) (Ježek 2009a).

Material examined: Pryskyřičný důl Valley (30), ô, 10.6.2010, MT, INS 19458.

Comments: Rather rare European species. Currently known to occur in Bulgaria, Czech Republic, France, Germany and Slovakia - Oboňa \& Ježek (2014) and Ježek et al. (2020). A nationaly scarce species in CZ.

Berdeniella longispinosa (Vaillant, 1958) - NS

Material examined: Pryskyřričný důl Valley (30), đ̂, 10.6.2010, MT, INS 19453; Zadní Doubice (Křinice River) (51), $2 \hat{\jmath} \widehat{\jmath}, 10.6 .2010$, MT, INS 19303 and 19307.

Comments: A rare European species collected in Spain, Austria, former Yugoslavia (Serbia and Montenegro) and Czech Republic (Jeseníky PLA, newly České Śvýcarsko NP) - see Wagner (2018), Krek (1999) and Ježek (2006b), nationaly scarce species in CZ, new for Bohemia.

Berdeniella manicata (Tonnoir, 1920)

Material examined: Brtnický most Bridge (7), ô, 8.6.2004, MT, INS 16343; Brtnický potok Brook env. Brtníky (8), đ̂, 1.6.2009, MT, INS 18399; Meanders of Chřibská Kamenice River (23), ô, 15.8.2005, MT, INS 16465; Pryskyřičný důl Valley (30), $\hat{\alpha}, 2.6 .2008$, MT, INS 17102; $\hat{\alpha}, 10.6 .2010$, MT, INS 19459; Vlčí potok Brook (48), ठ̂, 17.5.2010, MT, INS 19344; Zadní Jetřichovice (52), ठ̂, 1.6.2009, INS 18315.

Comments: European species (registered in 17 countries), penetrates to Transcaucasia (Georgia) - see Krek (1999) and Ježek et al. (2020). Common in places, known in the Czech Republic from low altitudes (brooks in a vicinity of Prague) to high elevation (slope spring areas of Jeseníky Mts.).

Berdeniella matthesi (Jung, 1954)

Material examined: Vlčí potok Brook (48), đ̂, 17.5.2010, MT, INS 19335.

Comments: A locally common species in Europe, known from Austria, Czech Republic, Germany, Italy, Slovakia and Ukraine - Ježek (2003) and Ježek et al. (2019), ranging from hilly areas to mountains, inhabiting wet extreme biotopes of open-cast coal mines and dumps (Sokolov basin) with floculated Fe.

Berdeniella pyrenaica Vaillant, 1976 - NS

Published records: Brtnický potok Brook env. Brtníky (8), Srbská Kamenice (north-eastern part) (37) (Ježek 2009a).

Material examined: Zadní Jetřichovice (52), ô, 10.6.2010, MT, INS 19433.

Comments: European species, rare, recorded only from Czech Republic, France and Spain so far (Ježek 2009a, Ježek et al. 2008), nationally scarce, suitable for a next monitoring.

Berdeniella stavniensis (Krek, 1969)

Material examined: Brtnický potok Brook env. Brtníky (8), ふૈ, 9.6.2004, Chvojka leg., SW, INS 15083;

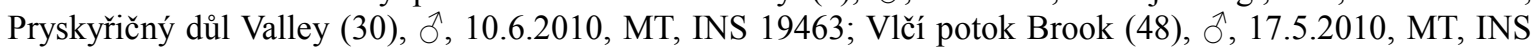
19343; Zadní Jetřichovice (52), đ̂, 8.6.2004, Ježek leg., SW, INS 13104.

Comments: European species, common sporadically, known from Austria, Bosnia and Herzegovina, Czech Republic, France, Germany, Serbia, Slovakia and Ukraine (Krek 1999, Ježek 2003, Ježek et al. 2017, 2019). Habitats: wet deep forest ravines, slope springs and dump seepages of open-cast coal mines (e. g. Sokolov coal basin).

Berdeniella unispinosa (Tonnoir, 1919)

Material examined: Brtnický potok Brook env. Brtníky (8), ô, 9.6.2004, Chvojka leg., SW, INS 15081;

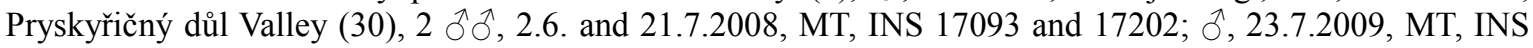
18357; Severák (35), Ô, 24.6.2008, Ježek leg., SW, INS 17003; Starý mlýn Mill (40), ô, 7.6.2004, Ježek leg., SW, INS 15170; Vlčí potok Brook (48), đ̂, 20.7.2009, MT, INS 18375; Zadní Doubice (Křinice River) (51), đ̊, 20.7.2009, MT, INS 18342; Zadní Jetřichovice (52), đ̂, 8.6.2004, Ježek leg., SW, INS 13100.

Comments: European species, 19 countries. Distribution: Central European zone from France to Poland and Slovakia, on the south the species penetrates to Apennines and Balkan. Rather common in our boundary mountains. An overview of the detailed distribution is given e.g. by Krek (1999) and Ježek et al. (2019, 2020). 
Clytocerus (Boreoclytocerus) dalii (Eaton, 1893)

Material examined: Dolský mlýn Mill (11), ㅇ, 15.6.2005, MT, INS 14309; Ponova louka Meadow (29), §̂, 20.6.2006, MT, INS 15087; Růžovský vrch Hill (32), ô, 17.5.2010, MT, INS 19380; Severák (35), ठิ, 12.8.2008, ET, INS 17136; Suchá Bělá, pond (42), ô, 15.6.2005, MT, INS 14292.

Comments: European species, rather rare, known from 10 countries - Ježek et al. (2019), Oboňa et al. (2019) and Morelli \& Biscaccianti (2021). Habitats: outflows of mountainous peat-bogs, forest spring areas, ponds and inundated meadows. Bionomy unknown.

Clytocerus (Boreoclytocerus) longicorniculatus Krek, 1987 - NS

Material examined: Dolský mlýn Mill (11), ô, 25.10.2004, MT, INS 16463; Nad Edmundovou soutěskou Gulch (27), đ̃, 28.5.2008, Ježek leg., SW, INS 17008; Růžovský vrch Hill (32), đ̂, 17.5.2010, MT, INS 19379; Vlčí

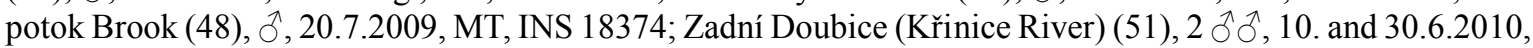

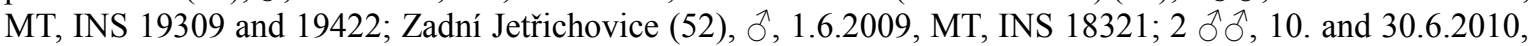
MT, INS 19319 and 19440.

Comments: A species hitherto known only from eight European countries - Ježek et al. (2020). This species has been probably overlooked generally in alcohol samples in the past and mistaken during an superficial identification for C. ocellaris. Apparently important species for the nature conservation, a monitoring will be badly needed (NS).

Clytocerus (Boreoclytocerus) ocellaris (Meigen, 1804)

Material examined: between Jetřichovice and Starý mlýn Mill (3), đ̂, 8.6.2004, Ježek leg., SW, INS 13152; between Vysoká Lípa and Jetřichovice (5), §ૈ, 8.6.2004, Ježek leg., SW, INS 14384; Brtnický potok Brook env. Brtníky (8), đ̊ 1.6.2009, MT, INS 18382; Dolský mlýn Mill (11), đ̂, 15.6.2005, MT, INS 14318; Jetřichovice, Jetřichovická Bělá Brook (17), đ̂, 7.6.2004, Ježek leg., SW, INS 13085; Kopec nr. Brtníky (18), ô, 15.6.2005, Ježek leg., SW, INS 16477; Krásná Lípa, pond (20), ô, 14.6.2005, Ježek leg., SW, INS 14380; Meanders of Chřibská Kamenice River (23), 4 đo ô, 15.6., 15.7., 15.8. and 20.9.2005, MT, INS 14333, 15131, 16366 and 16475; Mikulášovice - upper station (25), đ̂, 15.6.2005, Ježek leg., SW, INS 15191; Nad Edmundovou soutěskou Gulch (27), đ̂, 28.5.2008, Ježek leg., SW, INS 17009; Růžovský vrch Hill (32), ô, 17.5.2010, MT, INS 19374; Rynartice - Weidlichova kaple Chapel (34), ô, 9.6.2004, Ježek leg., SW, INS 14344; Severák (35), đ, 12.8.2008, ET, INS 17135; Srbská Kamenice (north-eastern part) (37), wet meadow, đ̂, 30.5.2006, Ježek leg., SW, INS 15236; Starý mlýn Mill (40), đ̄, 7.6.2004, Ježek leg., SW, INS 15169; Suchá Bělá, pond (42), $\hat{\jmath}$, 22.5.2005, MT, INS 15121; Šluknov - údolí Valley (44), $\hat{\jmath}, 11.9 .2008$, Ježek leg., SW, INS 16995; Vlčí Hora - Zahrady (47), ô, 22.6.2004, Ježek leg., SW, INS 13096; Vlčí potok Brook (48), 2 đิ ô, 17.7. and 20.8.2006, MT, INS 15076 and 16476; $2 \partial^{\lambda}$, 1.6. and 21.9.2009, INS 18272 and 18465; $\partial^{\lambda}, 17.5 .2010$, MT, INS 19334; Zadní Doubice (Křinice River) (51), 3 đo $\sigma^{7}, 17.6 ., 20.7$. and 7.10.2009, MT, INS 18291, 18338 and 18449; $2 \hat{\partial}^{\lambda} \hat{\alpha}, 10$. and 30.6.2010, MT, INS 19301 and 19420; Zadní Jetřrichovice (52), $\hat{\partial}, 1.6 .2009$, MT, INS 18310; 2 के $\hat{O}^{2}, 10$. and 30.6.2010, MT, INS 19311 and 19431.

Comments: Geographical distribution: Central and West Europe (incl. British Isles), the northern frontier of the area of distribution lies in Finland, the southern border is limited by Apennines and Balkan, the species penetrates eastwards to Lithuania. Occassionally massive presence in Malaise - and yellow pan traps. Very common species inhabiting banks of water flows and reservoirs, spring areas and wet meadows. An overview of the detailed distribution is given by Ježek et al. (2019, 2020) and Morelli \& Biscaccianti (2021).

Clytocerus (Boreoclytocerus) splendidus Ježek \& Hájek, 2007 - NS

Material examined: Vlčí potok Brook (48), 2 ô $\partial^{\top}, 1.6$. and 21.9.2009, MT, INS 18278 and 18476; Zadní Doubice (Křinice River) (51), ô, 20.7.2009, MT, INS 18347; Zadní Jetřichovice (52), ô, 1.6.2009, MT, INS 18323.

Comments: Species known only from Belgium, Czech Republic (localities from Orlické hory PLA, Železné hory PLA, Sokolovsko area, České Budějovice environment, Jeseníky PLA, Česko-moravské mezihoří area, Podyjí NP and Bílé Karpaty PLA), Poland and Slovakia - see Ježek et al. (2018, 2019) and Kroča \& Ježek (2019). Inhabits lakes, forest ponds, wetlands, rivers, streams and wet pastures. Nationally scarce (NS).

Parabazarella subneglecta (Tonnoir, 1922)

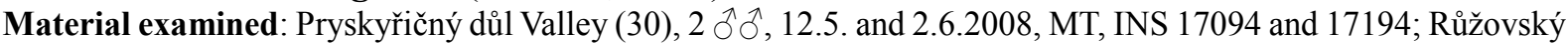
vrch Hill (32), đ̂, 17.5.2010, MT, INS 19385; Vlč́i potok Brook (48), đ̂, 17.5.2010, MT, INS 19339; Zadní

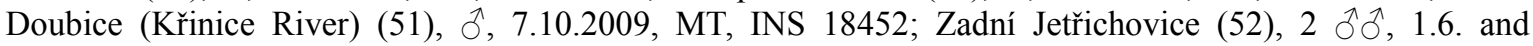
21.9.2009, MT, INS 18312 and 18423.

Comments: A species of Eurasiatic distribution, not common, known in Central European zone (from Belgium to Poland, eastwards to Lithuania). The northern border of its occurence in Europe lies in the boreal Scandinavian ecoregion (Finland), the southern frontier is limited by Balkan and Anatolia. A detailed distribution is given by Ježek et al. (2020). 


\section{Pericoma (Pachypericoma) blandula Eaton, 1893}

Material examined: between Doubice and Dolní Chřibská (2), ô, 9.6.2004, Ježek leg., SW, INS 15205; between Vysoká Lípa and Jetřichovice (5), ô, 8.6.2004, Ježek leg., SW, INS 14383; Bílý potok Brook (6), ô, 21.7.2008, MT, INS 17049; Brtnický potok Brook env. Brtníky (8), ô, 9.6.2004, Chvojka leg., SW, INS 15082; Brtníky env. Mikulášovice, Brtnický potok Brook (9), $\widehat{o}, 15.6 .2005$, Ježek leg., SW, INS 15158; Dolský mlýn Mill

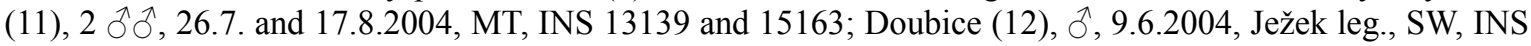
13055; Ferdinandova soutěska Gulch (13), ô, 7.6.2004, Chvojka leg., SW, INS 14364; Kopec nr. Brtníky (18), đ, 15.6.2005, Ježek leg., SW, INS 16409; Krásná Lípa, brook (19), ô, 17.6.2005, Ježek leg., SW, INS 15197; Křrinice River (21), đ̊, 21.7.2008, MT, INS 17070; Meanders of Chřibská Kamenice River (23), 3 đo 0 , 15.6 . and 24.6.2004, 15.8.2005, Ježek leg., SW, MT, INS 13110, 14332 and 16408; Nad Edmundovou soutěskou Gulch (27), ô, 23.-27.6.2008, Trýzna + Ježek leg., YPT, INS 17063; Pavlínino údolí Valley env. Jetřichovice (28), đ̂, 10.6.2004, Chvojka leg., SW, INS 14387; Pryskyřičný důl Valley (30), 3 đે ô, 12.5., 2.6. and 21.7.2008,

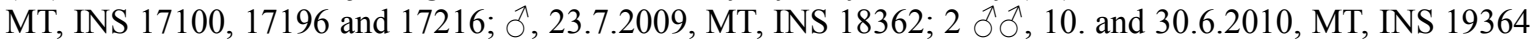
and 19462; Rủžovský vrch Hill (32), đ̂, 30.6.2010, MT, INS 19468; Rybniště env. Krásná Lípa (33), ô, 21.6.2004, Ježek leg., SW, INS 15216; Rynartice - Weidlichova kaple Chapel (34), ô, 9.6.2004, Ježek leg., SW, INS 14347; Severák (35), đ̂, 24.6.2008, Ježek leg., SW, INS 17017; Vlč́i potok Brook (48), ô, 12.5.2008,

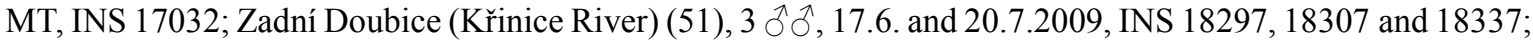

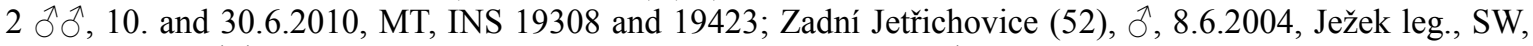
INS 13101; $2 \hat{\delta} \hat{\delta}$, 1.6. and 21.9.2009, MT, INS 18314 and 18432; $\hat{\partial}, 10.6 .2010$, MT, INS 19447.

Comments: P. blandula is very widely distributed in Europe, well known from 30 countries - see Ježek et al. (2019, 2020), common. Recorded in Transcaucasia (Abkhazia, Armenia, Azerbaijan, Georgia) and North Africa (Morocco, Tunisia), as well as in Mediterranean Sea (Sardinia), inhabiting quite different altitudes, prefers wet moss cover in shaded or non-shaded habitats.

\section{Pericoma (Pachypericoma) fallax Eaton, 1893}

Material examined: between Dolský mlýn Mill and Královský smrk Spruce (1), §̂, 7.6.2004, Ježek leg., SW, INS 13052; between Doubice and Dolní Chřibská (2), đ̂, 9.6.2004, Ježek leg., SW, INS 15204; Brtnický most

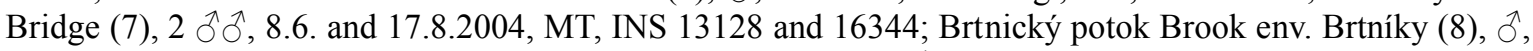
1.6.2009, MT, INS 18385; Ferdinandova soutěska Gulch (13), Oे, 7.6.2004, Chvojka leg., SW, INS 14365; Jetřichovice - swimming pool (16), đ̂, 10.6.2004, Ježek leg., SW, INS 15126; Meanders of Chřibská Kamenice River (23), đ̂, 20.9.2005, MT, INS 16365; Pavlínino údolí Valley env. Jetřichovice (28), đ̂, 10.6.2004, Chvojka

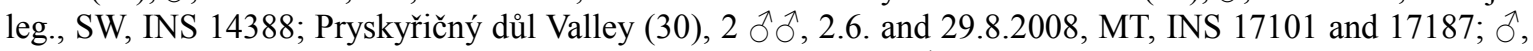
10.6.2010, MT, INS 19454; Rybniššě env. Krásná Lípa (33), đo, 21.6.2004, Ježek leg., SW, INS 15215; Rynartice - Weidlichova kaple Chapel (34), đ̄, 9.6.2004, Ježek leg., SW, INS 14342; Sněžná nr. Krásná Lípa (brook) (36), đે, 21.6.2004, Ježek leg., SW, INS 14358; Starý mlýn Mill (40), đે, 7.6.2004, Ježek leg., SW, INS

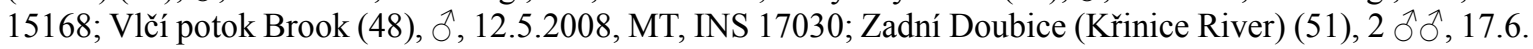
and 7.10.2009, INS 18308 and 18463; 2 đో, 10. and 30.6.2010, MT, INS 19300 and 19417; Zadní Jetřichovice

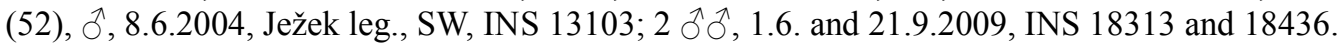

Comments: European and West-Siberian species, common and abundant, recorded in 20 countries, penetrates to Turkey, Transcaucasia (Abkhazia, Armenia, Azerbaijan, Georgia) and North Africa (Algeria, Morocco, Tunisia) as well as in Mediterranean sea (Sardinia). A list of the detailed distribution is given by Ježek et al. $(2019,2020)$.

\section{Pericoma (Pachypericoma) nielseni Kvifte, 2010 - NS}

Published records: between Doubice and Dolní Chřibská (2), Brtnický most Bridge (7), Dolský mlýn Mill (11), Pryskyřičný důl Valley (30) (Ježek 2009a).

Material examined: Pryskyřičný důl Valley (30), đ̂, 10.6.2010, MT, INS 19461; Pryskyřičný důl Valley - peat bogs (31), ô, 25.8.2009, MT, INS 18405.

Comments: European species, taxonomically underestimated, rather rare, recognized as valid at first recently, overlooked in the past. Distribution: Belgium, Czech Republic, Denmark, Finland, France, Norway, Slovakia and Ukraine (Ježek et al. 2020). Nationally scarce (NS).

\section{Pericoma (Pericoma) pseudexquisita Tonnoir, 1940}

Material examined: Brtnický potok Brook env. Brtníky (8), ô, 9.6.2004, Chvojka leg., SW, INS 15080; Hadí

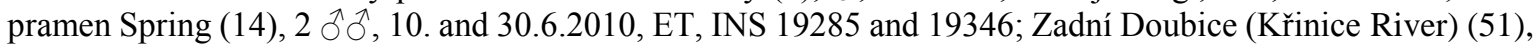
ग, 17.6.2009, INS 18309 .

Comments: European species known from 21 countries - West Europe (including British Isles), Central Europe and South Europe (Apennines and Balkan), details see Krek (1999), Ježek et al. (2020) and Morelli \& Biscaccianti (2021). 


\section{Pneumia cubitospinosa (Jung, 1954) - EN}

Material examined: Hadí pramen Spring (14), 2 ઈึิ, 17.5. and 10.6.2010, ET, INS 19348 and 19402.

Comments: Rare European species with following geographical distribution: Bosnia, Czech Republic, Denmark, France, Germany, Italy, Poland, Slovakia, Switzerland - Ježek (2003, 2006a) and Oboňa \& Ježek (2014). Biotopes: rills of forest slopes. Endangered in $\mathrm{CZ}(\mathrm{EN})$.

Pneumia mutua (Eaton, 1893)

Material examined: Brtníky env. Mikulášovice, Brtnický potok Brook, (9), ふૈ, 15.6.2005, Ježek leg., SW, INS 15176; Brtníky x Mikulášovice (10), ô, 15.6.2005, Ježek leg., SW, INS 15211; Hadí pramen Spring (14), Õ,

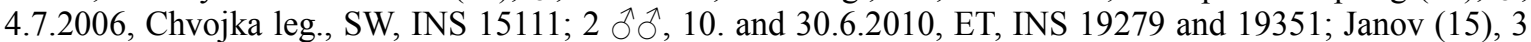

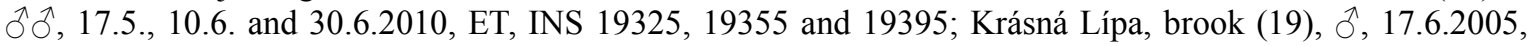
Ježek leg., SW, INS 15183; Krásná Lípa, pond (20), ô, 14.6.2005, Ježek leg., SW, INS 14379; Mikulášovice - upper station (25), ô, 15.6.2005, Ježek leg., SW, INS 15192; Pryskyřičný důl Valley (30), ふૈ, 22.6.2006, VÚLHM leg., MT, INS 16471; Růžovský vrch Hill (32), ð̊, 26.5.2008, Ježek leg., SW, INS 17015; 2 ô, 17.5. and 30.6.2010, MT, INS 19384 and 19476; Severák (35), đ̃, 24.6.2008, Ježek leg., SW, INS 17007; Srbská Kamenice (north-eastern part) (37), ô, 30.5.2006, Ježek leg., SW, INS 15229; Srbská Kamenice (western part) (38), đ̃, 30.5.2006, Ježek leg., SW, INS 15209; Vlčí Hora - Zahrady (47), ô, 22.6.2004, Ježek leg., SW, INS 13095; Vlčí potok Brook (48), đ, 1.6.2009, MT, INS 18277; Všemily env. Srbská Kamenice (49), đ, 30.5.2006, Ježek leg., SW, INS 15221.

Comments: European species, registerred from 18 countries, abundant. Known from countries along the Northern Sea and British Islands, eastwards penetrates to Poland and Lithuania. The northern border of its distribution lies in Scandinavia (Finland), the southern frontier is limited by Apennines and Balkan. In the Czech Republic common mostly in the Hercynicum (Orlické hory PLA, Jeseníky PLA and České Švýcarsko NP). More information generally see e.g. in Ježek (2006b), Ježek \& Hájek (2007), Wagner (2018) and Ježek et al. (2019).

Pneumia nubila (Meigen, 1818)

Material examined: Meanders of Chřibská Kamenice River (23), 3 $\widehat{\jmath}$, 24.6.2004, 15.7. and 15.8.2005, Ježek leg., SW, MT, INS 13111, 15133 and 16473; Rybniště env. Krásná Lípa (33), ô, 21.6.2004, Ježek leg., SW, INS 15214; Šluknov - údolí Valley (44), ô, 11.9.2008, Ježek leg., SW, INS 16998; Vlčí potok Brook (48), đે, 17.5.2010, MT, INS 19326.

Comments: Common European species (28 countries), one of the most abundant members of moth flies in the Czech Republic (especially in shaded habitats with decaying organic matter: ponds, brooks, spring areas, water reservoirs and swamps). Registered from Spain and British Isles throughout Scandinavia, Poland and Lithuania. The southern border of its distribution is limited by Apennines, Balkan and Transcaucasia (Abkhazia, Armenia, Azerbaijan, Georgia). Recorded also from Sardinia and Canary Islands. An overview of the detailed distribution is given by Ježek et al. (2019, 2020, 2021).

Pneumia palustris (Meigen, 1804)

Material examined: Růžovský vrch Hill (32), ô, 17.5.2010, MT, INS 19391.

Comments: Mainly European species (24 countries), detailed distribution: Albania, Austria, Belgium, Bosnia and Herzegovina, Croatia, Czech Republic, Denmark, Finland, France, Germany, Great Britain, Greece, Hungary, Ireland, Lithuania, Macedonia, Montenegro, the Netherlands, Poland, Romania, Serbia, Slovakia, Slovenia and Sweden. Penetrates to some islands as Canary I., Corsica, Crete, as well as to Turkey and Transcaucasia (Abkhazia, Georgia) - Ježek et al. (2019, 2020, 2021).

\section{Pneumia pilularia (Tonnoir, 1940)}

Material examined: Šluknov - údolí Valley (44), ô, 11.9.2008, Ježek leg., SW, INS 16997; Vlčí potok Brook

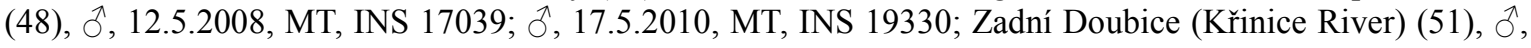
7.10.2009, INS 18451 .

Comments: A species known almost throughout Europe (17 countries), abundant sporadically. Registered in a zone from Spain and British Isles to Lithuania and covering as well boreal ecoregion (Scandinavia). It has been recorded also from North Africa (Algeria, Morocco) and Transcaucasia (central Caucasus - Terskol in Russia, Azerbaijan, Georgia, Tajikistan). Some details see Ježek et al. $(2019,2020,2021)$ and Morelli \& Biscaccianti (2021).

\section{Pneumia rivularis Berdén, 1954 - EN}

Material examined: Zadní Jetřichovice (52), đ̂, 30.6.2010, MT, INS 19318.

Comments: A Palaearctic species ranging from British Isles through boreal ecoregion (Scandinavia) to Far East, southern frontier is limited by Germany, Czech Republic (only Sokolov open-cast area, Železné hory PLA and newly České Švýcarsko NP) and Slovakia (Pol'ana PLA) - compare Ježek (2003, 2009b), Oboňa \& Ježek (2014) and Ježek et al. (2019). Endangered in CZ (EN). 
Pneumia trivialis (Eaton, 1893)

Material examined: between Doubice and Dolní Chřibská (2), đ̂, 9.6.2004, Ježek leg., SW, INS 15206; between Jetřichovice and Starý Mlýn (3), đ̊, 8.6.2004, Ježek leg., SW, INS 13151; between Vlčí Hora and Brtníky (4), đ̃, 22.6.2004, Ježek leg., SW, INS 13081; Bílý potok Brook (6), ô, 17.7.2006, MT, INS 15100; đ̃, 21.7.2008,

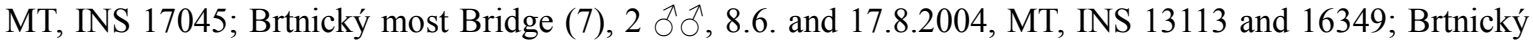
potok Brook env. Brtníky (8), đ̃, 9.6.2004, Chvojka leg., SW, INS 15078; đ̃, 1.6.2009, MT, INS 18383; Brtníky env. Mikulášovice, Brtnický potok Brook, (9), đ̃, 15.6.2005, Ježek leg., SW, INS 15174; Brtníky x Mikulášovice (10), ô, 15.6.2005, Ježek leg., SW, INS 15213; Dolský mlýn Mill (11), 3 đ̃ô, 26.7., 17.8. and 25.10.2004, MT, INS 13145, 15153 and 16514; Doubice (12), Ô, 9.6.2004, Ježek leg., SW, INS 13060; Jetřichovice - swimming pool (16), Ô, 10.6.2004, Ježek leg., SW, INS 15127; Jetřichovice, Jetřichovická Bělá Brook (17), đ̃, 7.6.2004, Ježek leg., SW, INS 13083; Kopec nr. Brtníky (18), ô, 15.6.2005, Ježek leg., SW, INS 16513; Krásná Lípa, brook (19), đ̃, 17.6.2005, Ježek leg., SW, INS 15182; Krásná Lípa, pond (20), đ̂, 14.6.2005, Ježek leg., SW, INS 14381; Křinice River (21), ô, 21.7.2008, MT, INS 17074; Limberk (22), ठ̂, 14.7.2006, VÚLHM leg., MT, INS 16510; Meanders of Chřibská Kamenice River (23), 4 $\widehat{\jmath}$ ô, 24.6.2004, 15.7., 15.8. and 20.9.2005, Ježek leg., SW, MT, INS 13109, 15130, 16350 and 16512; Mezní Louka (24), ふో, 14.7.2004, Chvojka leg., SW, INS 14389; Mikulášovice - upper station (25), đ̊, 15.6.2005, Ježek leg., SW, INS 15194; Ponova louka Meadow (29), đ̂, 29.5.2006, MT, INS 16515; Pyskyřičný důl Valley (30), 3 $\widehat{\jmath}$, 12.5., 2.6. and 29.8.2008, MT, INS 17088, 17173 and 17193; ð̄, 23.7.2009, INS 18354; Růžovský vrch Hill (32), $2 \hat{\jmath} \widehat{\jmath}, 29.5 .2006$, Ježek leg., SW, INS 15108 and 15186; $2 \hat{\jmath} \widehat{\jmath}, 26.5 .2008$, Ježek leg., SW, INS 17013

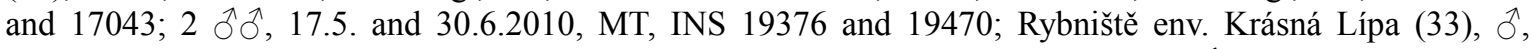
21.6.2004, Ježek leg., SW, INS 15201; Rynartice - Weidlichova kaple Chapel (34), đ̃, 9.6.2004, Ježek leg., SW, INS 14354; Severák (35), 4 đ̊̄, 12.5., 24.6. and 12.8.2008, Ježek leg., SW, ET, INS 17005, 17018, 17140 and 17141; Sněžná nr. Krásná Lípa (brook) (36), đ̃, 21.6.2004, Ježek leg., SW, INS 14359; Srbská Kamenice (north-eastern part) (37), đ̂, 30.5.2006, Ježek leg., SW, INS 15233; Srbská Kamenice (western part) (38), đ̃, 30.5.2006, Ježek leg., SW, INS 15210; Suchá Bělá, pond (42), 3 đ̄ô, 22.5., 15.6. and 20.9.2005, MT, INS 14298, 15134 and 16370; Šluknov-údolí Valley (44), ô, 11.9.2008, Ježek leg., SW, INS 16996; Tokáň (45), đ̃, 16.7.2004, Chvojka leg., SW, INS 13098; Vlčí potok Brook (48), 2 ふึَ, 17.7. and 20.8.2006, MT, INS 15063

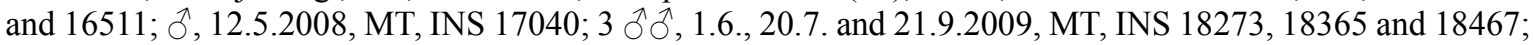
đ̄, 17.5.2010, MT, INS 19327; Všemily env. Srbská Kamenice (49), đ̋, 30.5.2006, Ježek leg., SW, INS 15219;

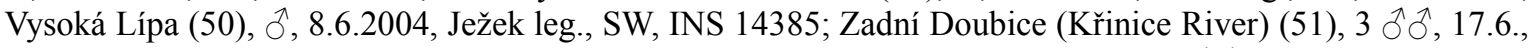
20.7. and 7.10.2009, MT, INS 18292, 18335 and 18443; Zadní Jetřichovice (52), 2 ふ઼े, 1.6. and 21.9.2009, MT, INS 18316 and 18421; đ̃, 30.6.2010, MT, INS 19315.

Comments: An ubiquitous European species (22 countries) with a large area of distribution, abundant, being among the most common species of the family, covering zone from Iberian Peninsula and British Islands to Poland and Ukraine (not recorded in Russia), penetrates to the boreal ecoregion (Scandinavia), the southern border is limited by Balkan. New sites are in Transcaucasia (Azerbaijan and Georgia). Occassionally numerous in Malaise - and yellow pan traps, in both shaded and unshaded habitats with decaying organic matter (ponds, brooks, spring areas, swamps, and water reservoirs) where larvae develop. In the Czech Republic is known a detailed occurence from the Hercynicum (western part and additionaly Orlické hory PLA, Jeseníky PLA, České Švýcarsko NP, etc.). A detailed distribution compare in Ježek et al. (2019, 2020, 2021).

Saraiella rotunda (Krek, 1970) - CR

Material examined: Hadí pramen Spring (14), ふૈ, 17.5.2010, ET, INS 19400; Janov (15), ふૈ, 17.5.2010, ET, INS 19397; Nad Edmundovou soutěskou Gulch (27), đે, 28.5.2008, Ježek leg., SW, INS 17011; Ponova louka Meadow (29), ふૈ, 29.5.2006, MT, INS 16490; Vlčí potok Brook (48), ふૈ, 17.5.2010, MT, INS 19337.

Comments: Probably Submediterranean mountainous species, known from Bosnia and Herzegovina, Bulgaria, Czech Republic, Italy, Kosovo, Macedonia, Poland, Serbia and Slovakia, penetrates to Transcaucasia (Azerbaijan, Georgia) - Ježek et al. $(2019,2020,2021)$. Sporadically abundant, critically endangered in CZ (CR).

Szaboiella hibernica (Tonnoir, 1940) - CR

Material examined: Hadí pramen Spring (14), $3 \hat{\partial} \partial$, 9.6.2004, 16.6.2005 and 4.7.2006, Chvojka leg., SW, INS

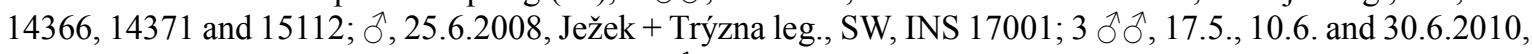
ET, INS 19282, 19350 and 19401; Mlýny (26), ô, 15.7.2004, Chvojka leg., SW, INS 14362.

Comments: European species (11 countries) with a zone of distribution covering Iberian Peninsula, British Isles, countries along Northern Sea and Central European region, Apennines and Balkan, penetrates to Transcaucasia (Abkhazia). Rather mountaineous species (400-1470 m a.s.l. in Europe, on Caucasus to $2350 \mathrm{~m}$ a.s.l.), habitats: streams with large stones and fallen trees, wallowing grounds, brooks, forest spring areas, rocky slopes, avalanche cirques, wells, riverine wetlands and pastures, ponds, soaks, swamps, bogs, swampy driveways of estate of cottages, wet queen of the prairie meadows, cribs, village polluted gutters - Ježek (2004, 2019). Critically endangered in $\mathrm{CZ}(\mathrm{CR})$. 
Tonnoiriella nigricauda (Tonnoir, 1919) - CR

Material examined: Brtnický most Bridge (7), đ̂, 17.8.2004, MT, INS 13119; Meanders of Chřibská Kamenice

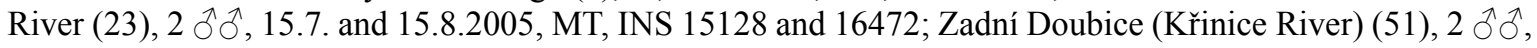
20.7. and 7.10.2009, MT, INS 18339 and 18458.

Comments: European species ( 8 countries), sporadically abundant. Distribution see in Kvifte et al. (2011), Wagner (2018) and Ježek et al. (2019). Critically endangered (CR) in CZ.

Tonnoiriella pulchra (Eaton, 1893)

Material examined: Vlč́ potok Brook (48), ô, 1.6.2009, INS 18284; Zadní Doubice (Křinice River) (51), ô, 20.7.2009, INS 18345.

Comments: Known from Western, Southern and Central Europe (Belgium, Bulgaria, Czech Republic, Greit Britain, France, Germany, Hungary, Ireland, Italy, Romania, Slovakia and Spain), not common. Also recorded in North Africa (Algeria, Morocco). Some datails see e. g. in Wagner (2018), Afzan \& Belqat (2016) and Ježek et al. $(2019,2020)$.

Ulomyia cognata (Eaton, 1893)

Material examined: Brtnický most Bridge (7), ô, 17.8.2004, MT, INS 13112; Brtnický potok Brook env. Brtníky (8), đ̂, 1.6.2009, INS 18384; Dolský mlýn Mill (11), ô, 15.6.2005, MT, INS 14307; Hadí pramen Spring (14),

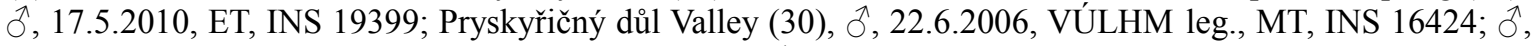
10.6.2010, MT, INS 19448; Růžovský vrch Hill (32), స̂, 17.5.2010, MT, INS 19378; Vlčí potok Brook (48),

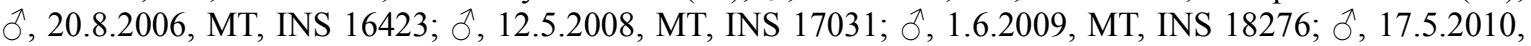
MT, INS 19336; Zadní Doubice (Křinice River) (51), ô, 10.6.2010, MT, INS 19286; Zadní Jetřichovice (52), ๙ิ, 10.6.2010, MT, INS 19436.

Comments: European species (12 countries), known also from Armenia and Georgia. A species of bryomadicolous and hygropetric habitats in different altitudes. In Europe, a very common species from lowlands to mountains (approximately 400-700 m a.s.1. - in western Hercynicum), but in Georgia at an elevation of 2050 to $3050 \mathrm{~m}$ a.s.l. An overview of the detailed distribution is given by Ježek et al. $(2019,2021)$.

Ulomyia fuliginosa (Meigen, 1804)

Material examined: between Vlčí Hora and Brtníky (4) đૈ, 22.6.2004, Ježek leg., SW, INS 13080; between Vysoká Lípa and Jetřichovice (5), đ̂, 8.6.2004, Ježek leg., SW, INS 14382; Brtnický potok Brook env. Brtníky (8), ภ̂, 9.6.2004, Chvojka leg., SW, INS 15079; Brtníky env. Mikulášovice, Brtnický potok Brook (9) đ̂, 15.6.2005, Ježek leg., SW, INS 15173; Brtníky x Mikulášovice (10), ô, 15.6.2005, Ježek leg., SW, INS 15212; Doubice

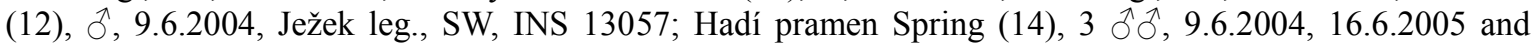
4.7.2006, Chvojka leg., SW, INS 14367, 14370 and 15110; $\partial^{2}$, + , 25.6. and 8.-12.9.2008, Ježek + Trýzna leg., SW, YPT, INS 17000 and 17117; $2 \hat{\partial} \partial^{\lambda}, 10$. and 30.6.2010, ET, INS 19281 and 19349; Janov (15), $\hat{\partial}$, 30.6.2010, ET, INS 19356; Jetřichovice, Jetřichovická Bělá Brook (17), ô, 7.6.2004, Ježek leg., SW, INS

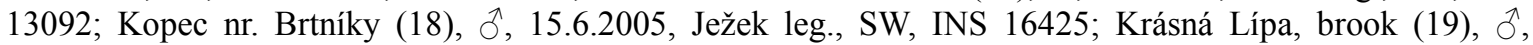
17.6.2005, Ježek leg., SW, INS 15181; Meanders of Chřibská Kamenice River (23), đૈ, 24.6.2004, Ježek leg., SW, INS 13107; Mikulášovice - upper station (25), đ̂, 15.6.2005, Ježek leg., SW, INS 15195; Mlýny (26), તે, 15.7.2004, Chvojka leg., SW, INS 14372; Pryskyřičný důl Valley (30), ô, 22.6.2006, VÚLHM leg., MT, INS

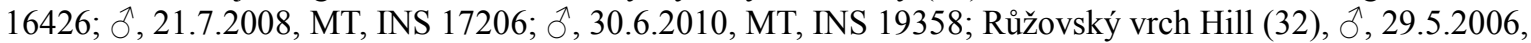

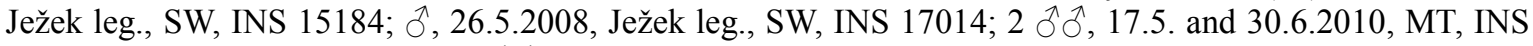

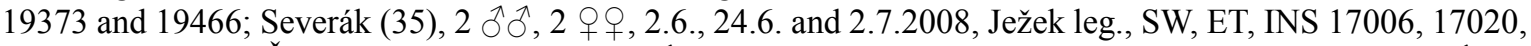
17123 and 17133; Šluknov-údolí Valley (44), ô, 11.9.2008, Ježek leg., SW, INS 16999; Eustach (46), đ, , +, 12.5. and 2.6.2008, MT, INS 17132 and 17152; Vlčí Hora - Zahrady (47), ô, 22.6.2004, Ježek leg., SW, INS

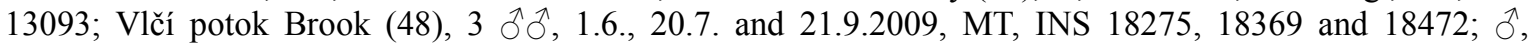
17.5.2010, MT, INS 19333; Všemily env. Srbská Kamenice (49), đ’, 30.5.2006, Ježek leg., SW, INS 15220.

Comments: Generally one of the most abundant species, widely distributed, known throughout nearly all of Europe (29 countries), ranging from lowlands to mountains. Data from eastern Europe are limited (only Lithuania). Sweep netting activities (SW) and traps (MT, YPT) show often a massive presence of this species on suitable different wet localities (see e. g. above the material examined). A detailed distribution is given by Wagner (2018) and Ježek et al. (2017, 2019, 2020).

Ulomyia undulata (Tonnoir, 1919) - CR

Material examined: Hadí pramen Spring (14), 2 đò, 9.6.2004 and 16.6.2005, Chvojka leg., SW, INS 14368 and 14369; $\hat{\partial}, 25.6 .2008$, Ježek + Trýzna leg., SW, INS 17002; $2 \hat{\partial} \hat{\partial}, 10$. and 30.6.2010, ET, INS 19280 and 19352; Růžovský vrch Hill (32), ô, 29.5.2006, Ježek leg., SW, INS 15187; đิ, 26.5.2008, Ježek leg., SW, INS 17016; $2 \hat{\jmath}$ ô, 17.5. and 30.6.2010, MT, INS 19382 and 19467.

Comments: European species, very rare, known from Austria, Belgium, Czech Republic (Bohemia - Kokořínsko PLA), France, Germany, Spain - Vaillant (1983), Ježek (2003, 2005), Ježek et al. (2018, 2022). Habitats: wet rocky walls (fauna hygropetrica), spring areas of untouched natural forests. Critically endangered in CZ (CR). 


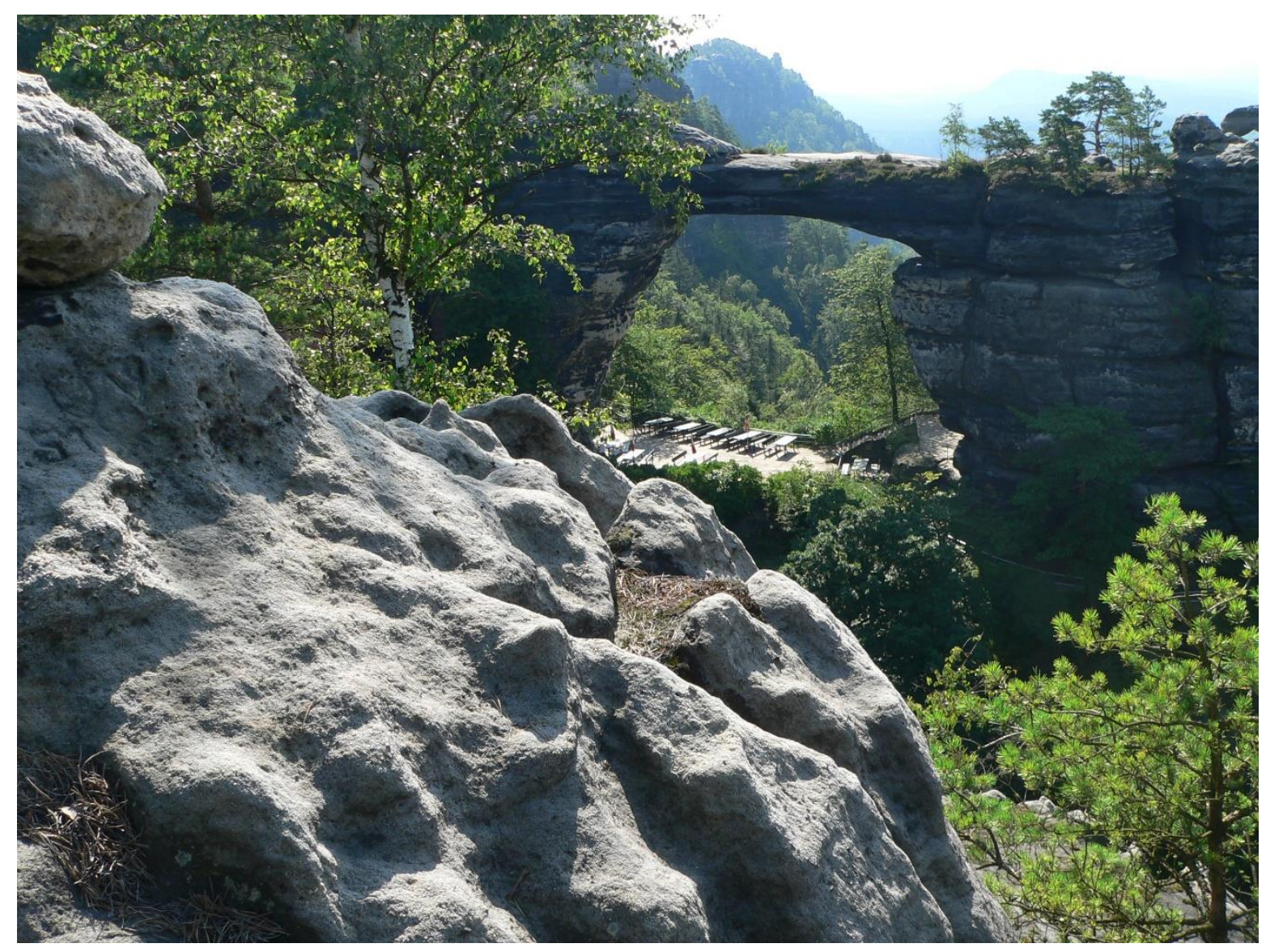

Fig 1: Pravčická brána arch, a largest rocky bridge in the Central Europe, České Švýcarsko NP, photo by Z. Vařilová.

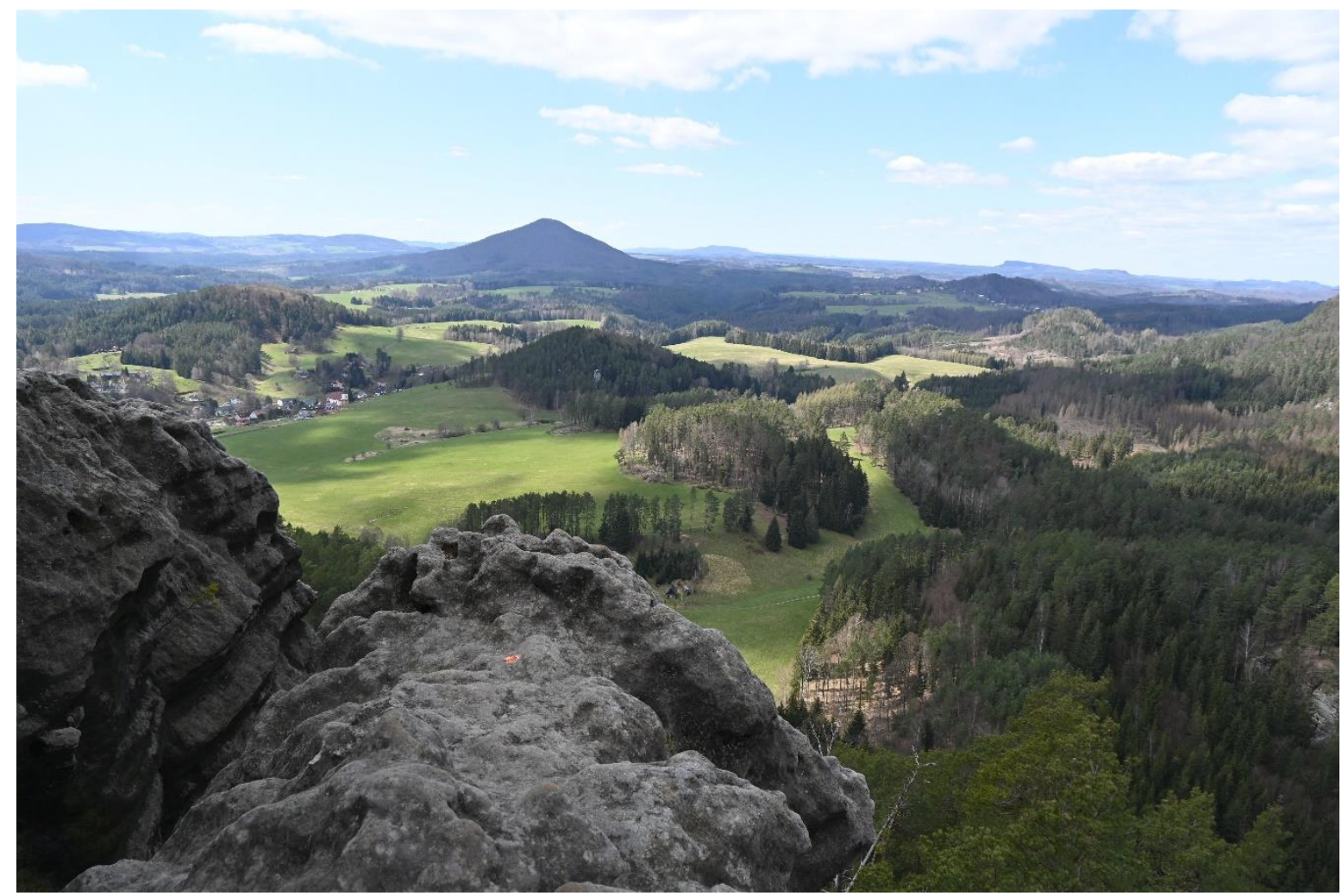

Fig 2: Landscape of Jetřichovice village vicinity (near Loc. 17), photo by Z. Vařilová. 


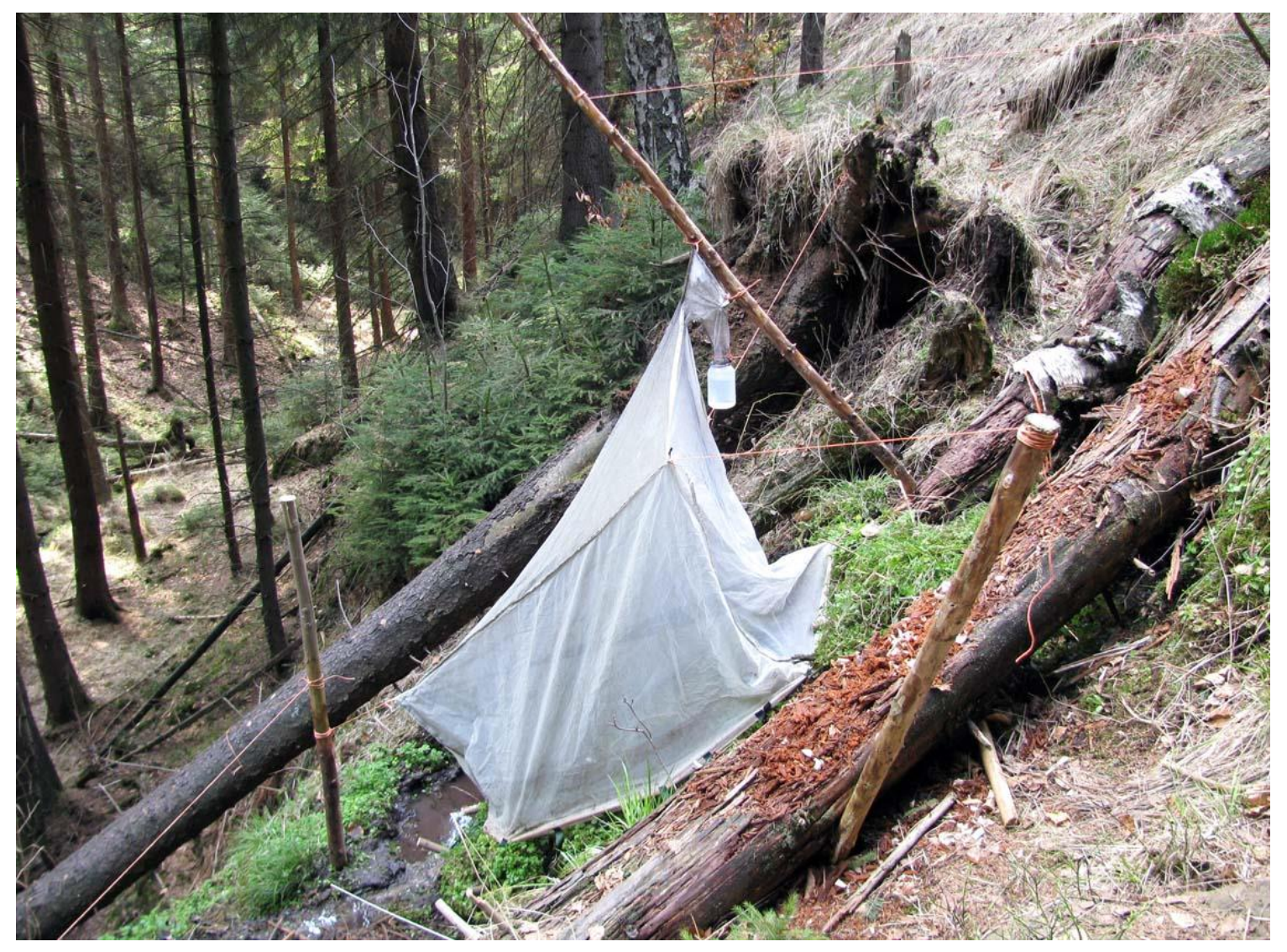

Fig 3: Hadí pramen Spring env. Zadní Doubice with installed emergent trap (Loc. 14), photo by P. Chvojka.

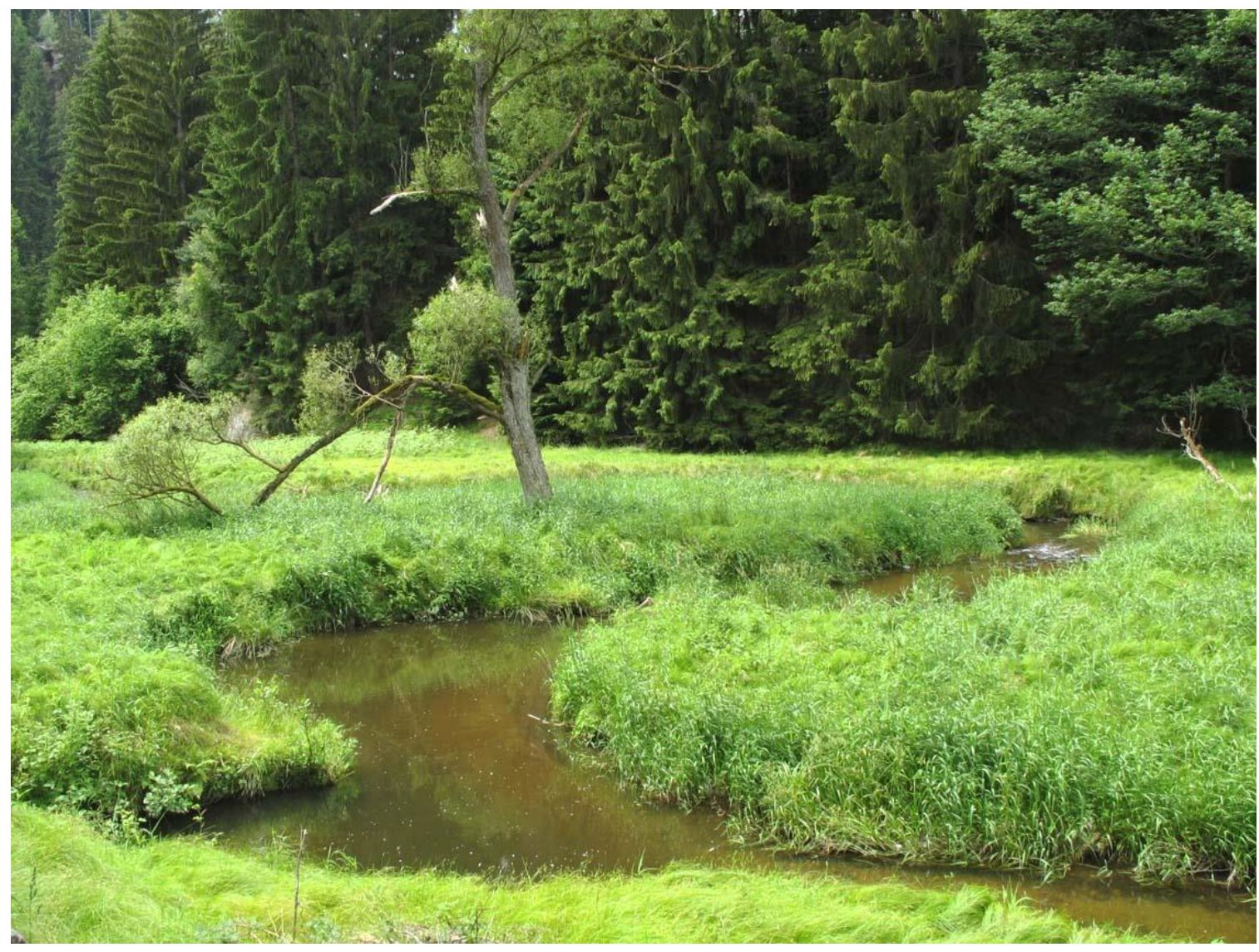

Fig 4: Meanders of Křinice River env. Zadní Doubice (Loc. 21), photo by P. Chvojka. 


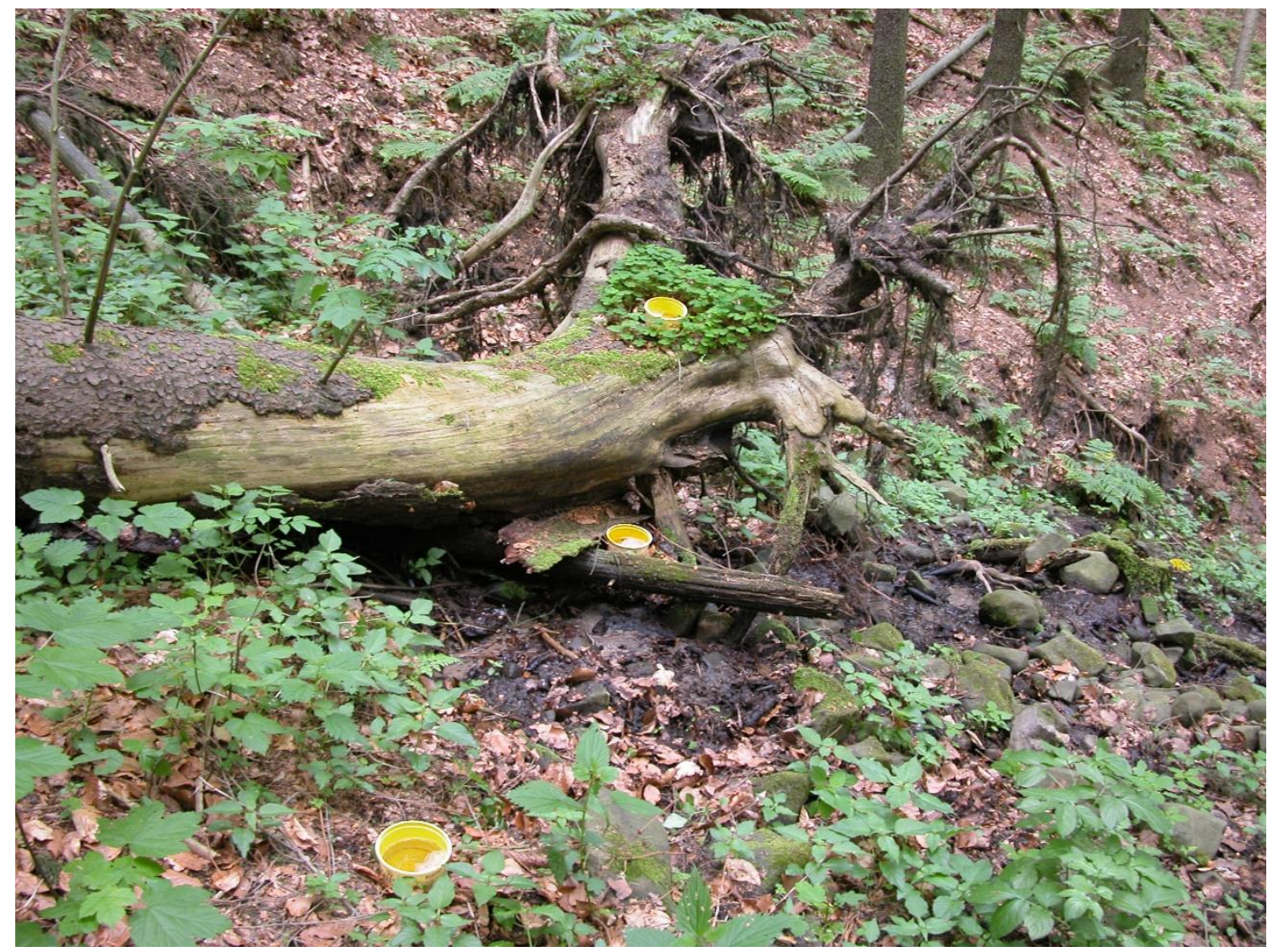

Fig 5: Mlýny, spring area, yellow pan traps, Loc. 26, photo by M. Trýzna.

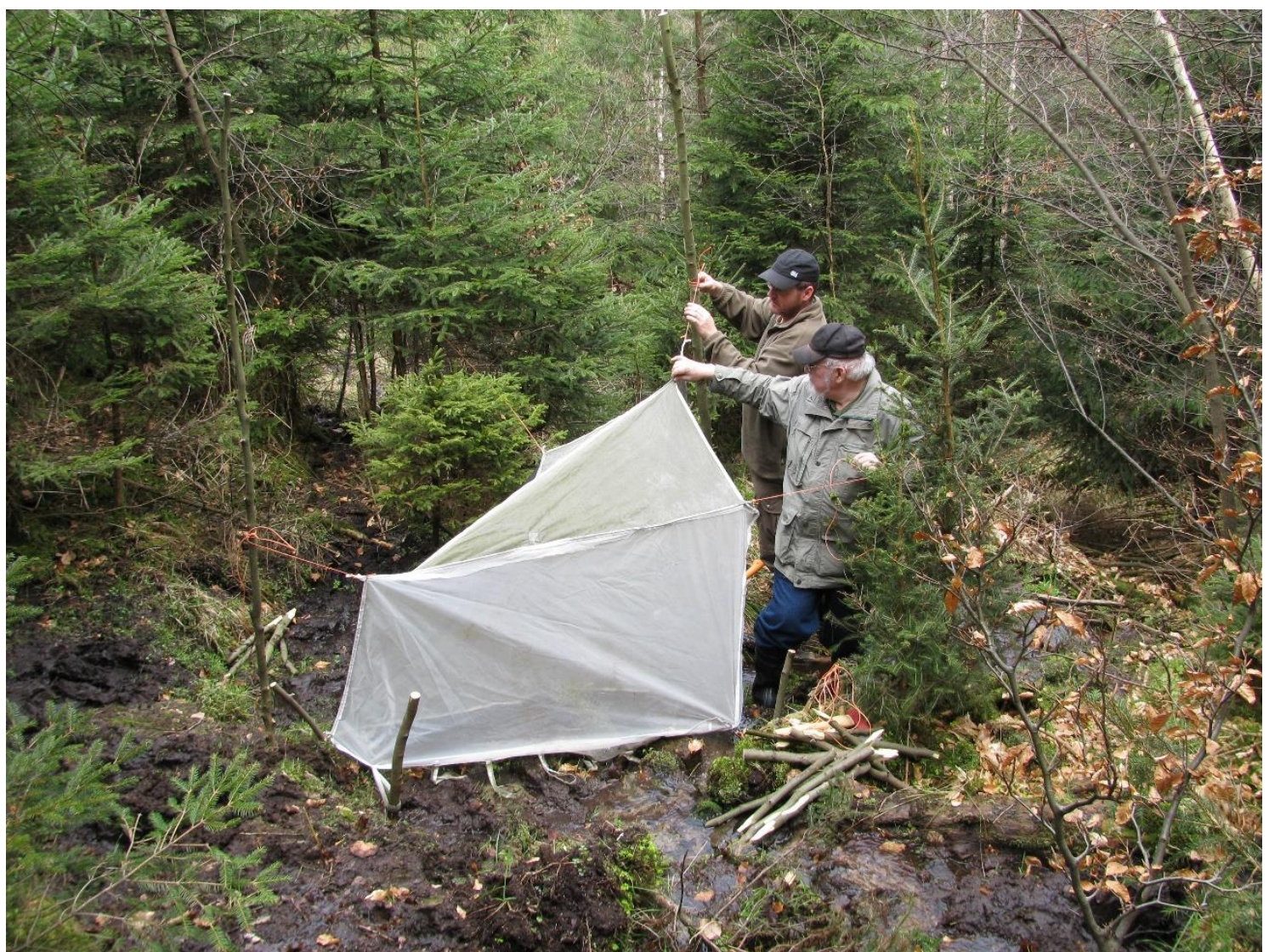

Fig 6: Nad Edmundovou soutěskou Gulch (Loc. 27), J. Ježek and M. Trýzna (hind person) with emergent trap, photo by P. Chvojka. 


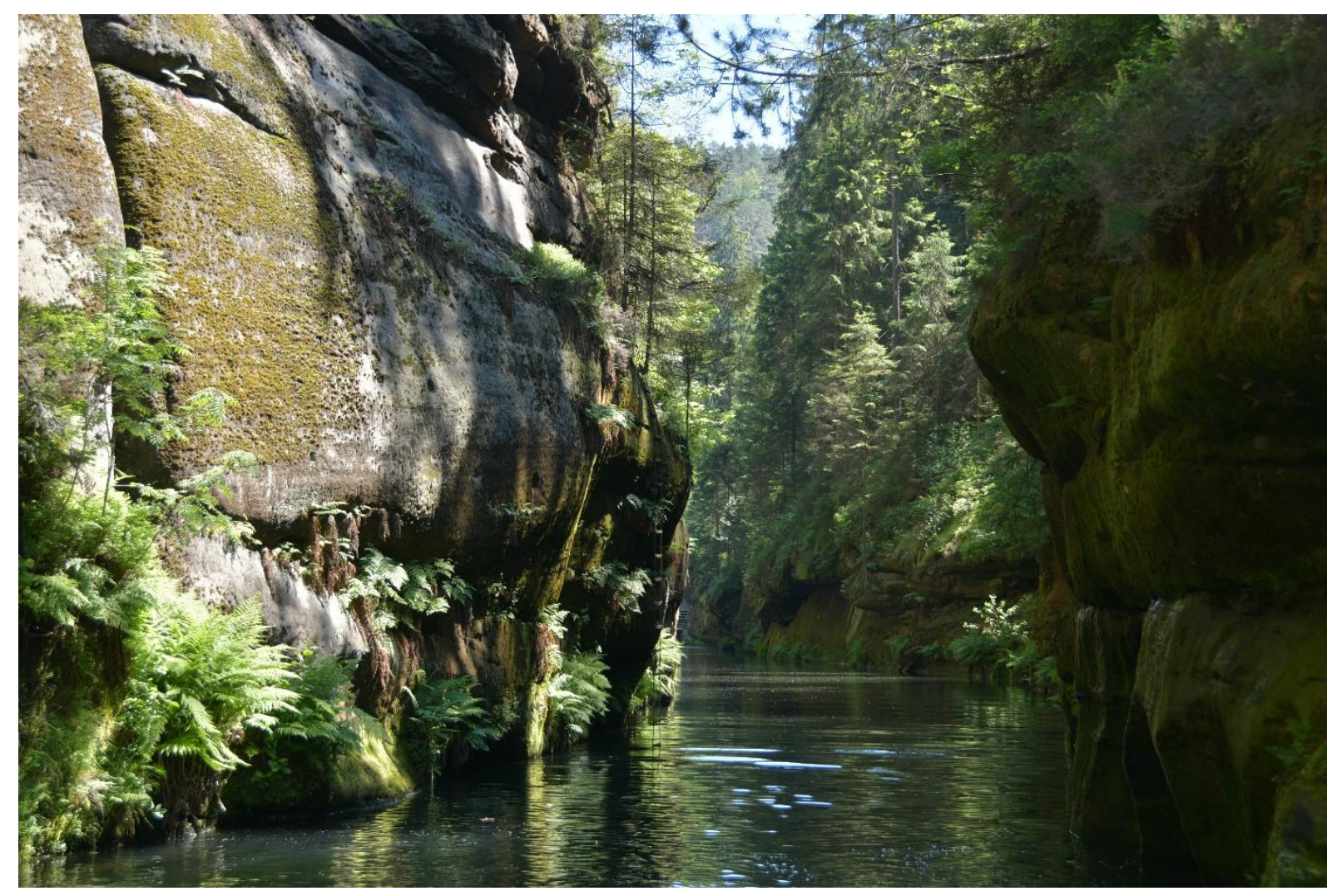

Fig 7: Upper part of Edmund's Gulch (near Loc. 27), photo by Z. Vařilová.

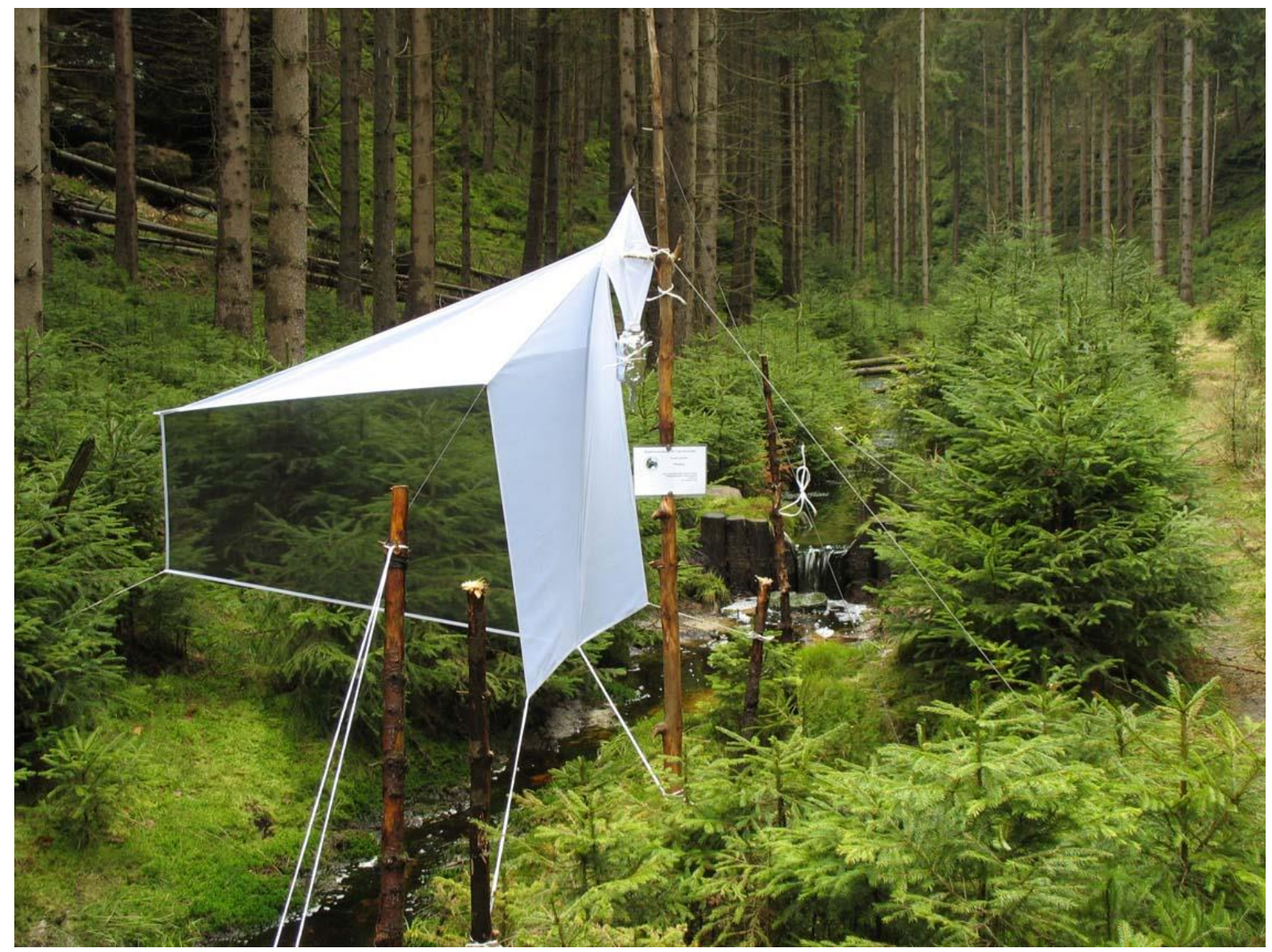

Fig 8: Pryskyrričný důl Valley (Loc. 30) - Malaise trap, photo by P. Chvojka. 


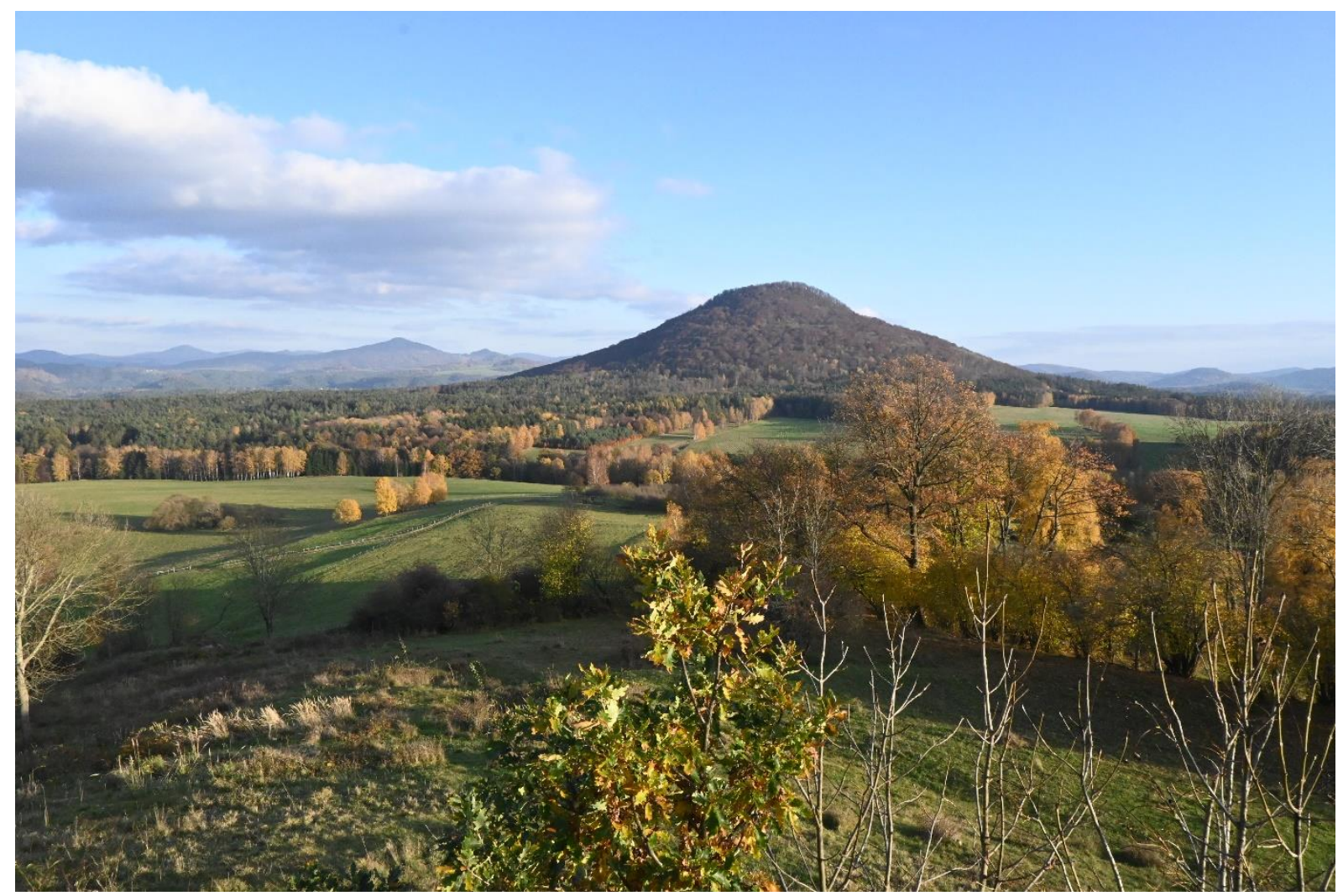

Fig 9: Růžovský vrch Hill, autumn scenery (Loc. 32), photo by Z. Vařilová.

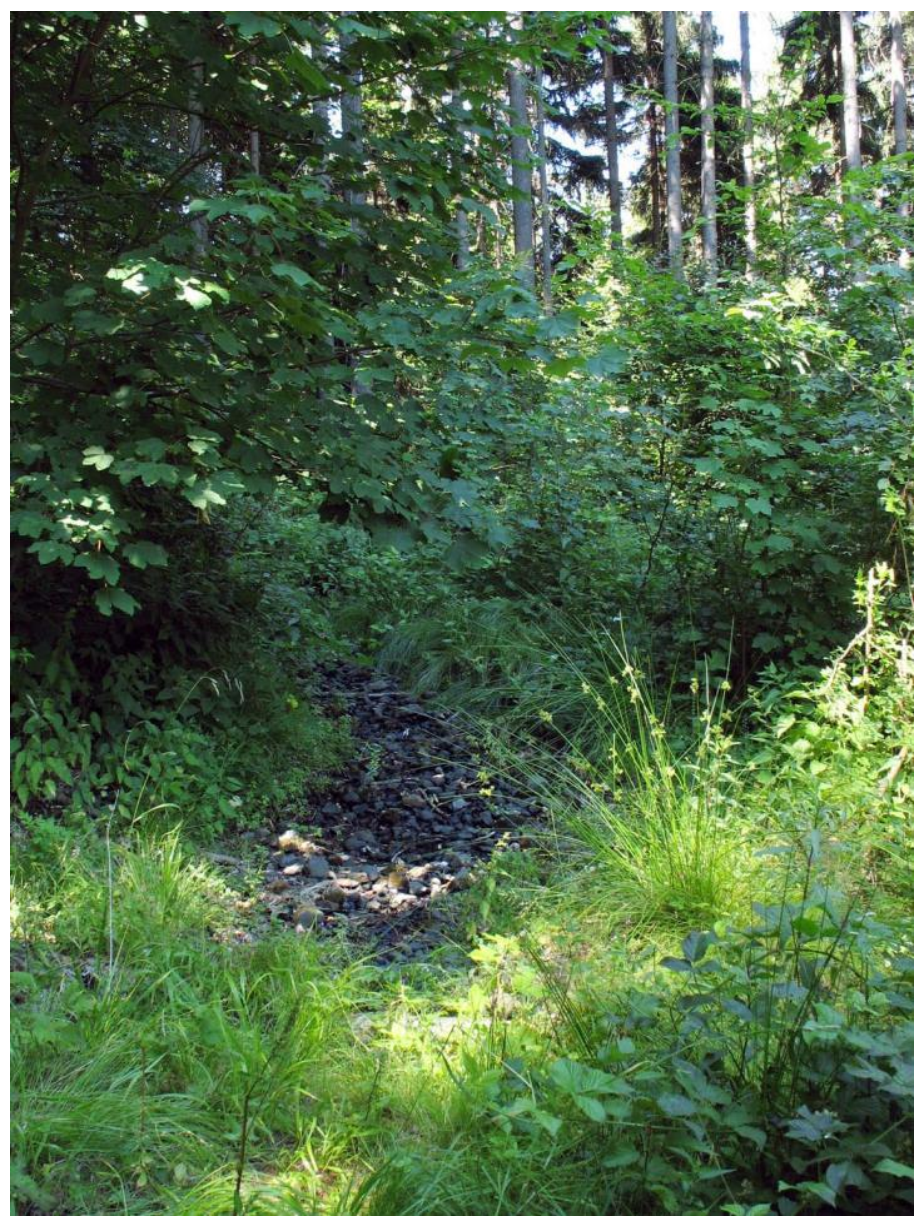

Fig 10: Růžovský vrch Hill (spring) - Loc. 32, photo by P. Chvojka. 


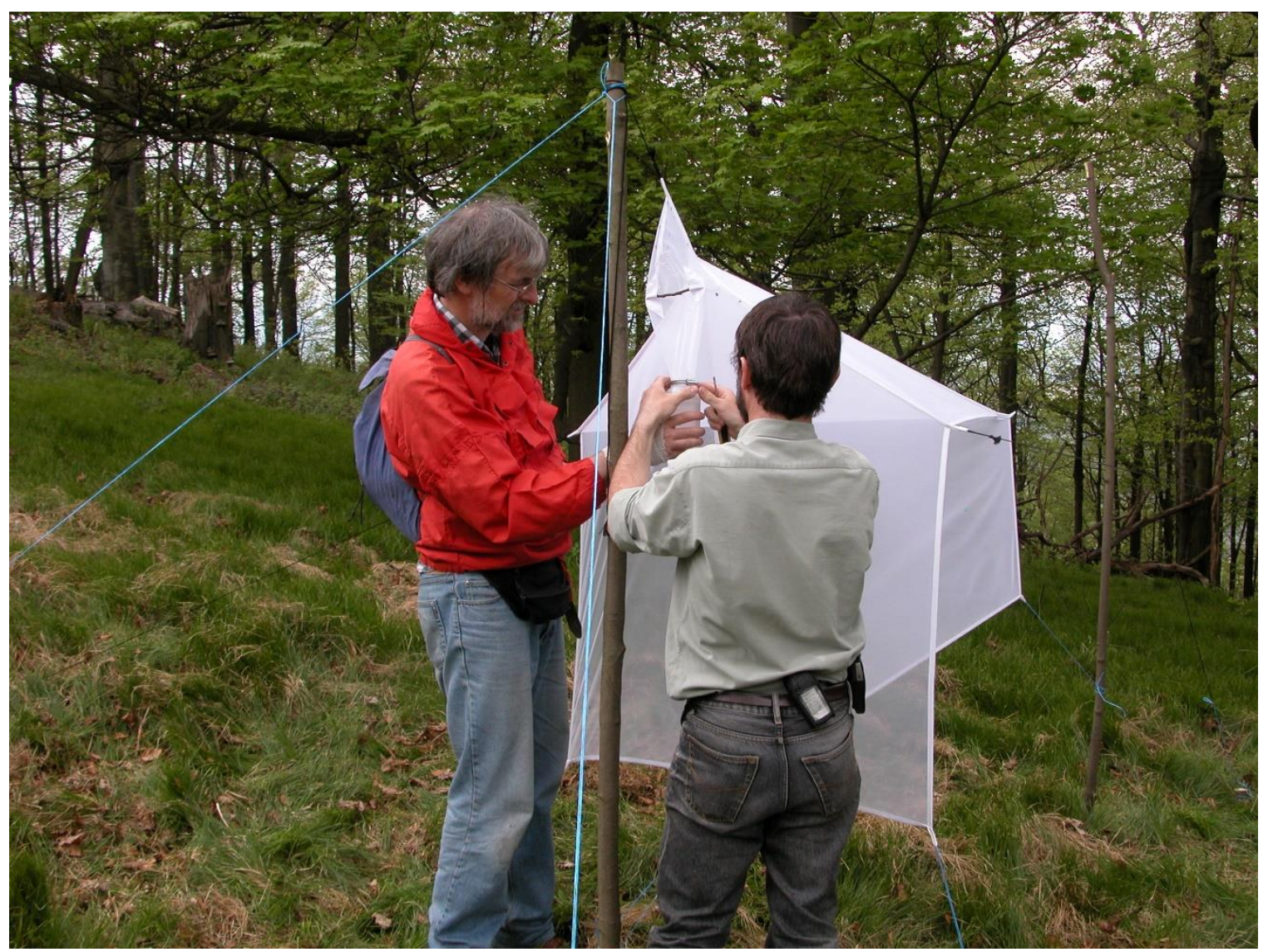

Fig 11: Růžovský vrch Hill (forest slope) - Loc. 32, emptied Malaise trap by J. Macek and P. Chvojka (right person), photo by M. Trýzna.

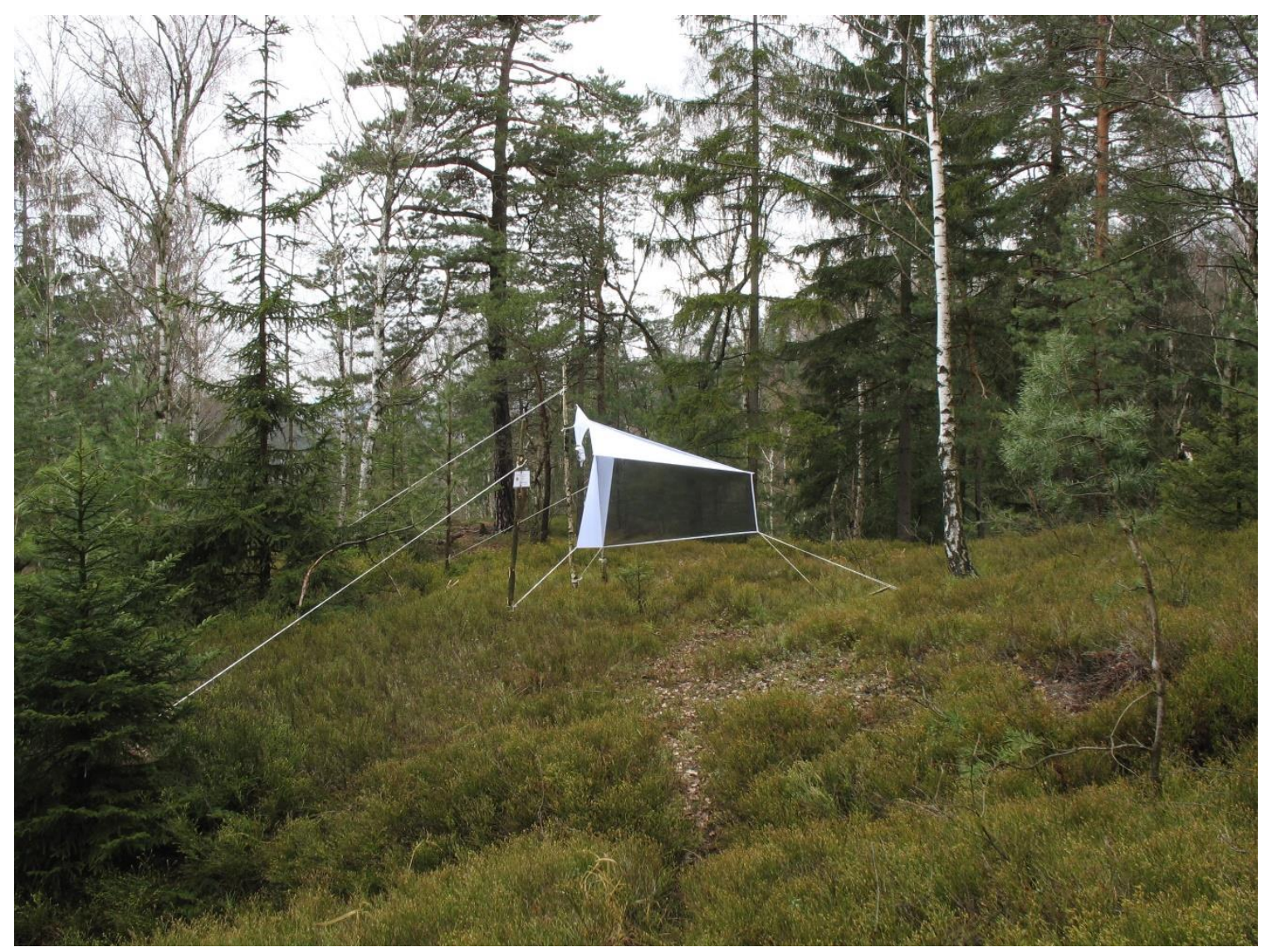

Fig 12: U svatého Eustacha - Malaise trap (Loc. 46), photo by P. Chvojka. 


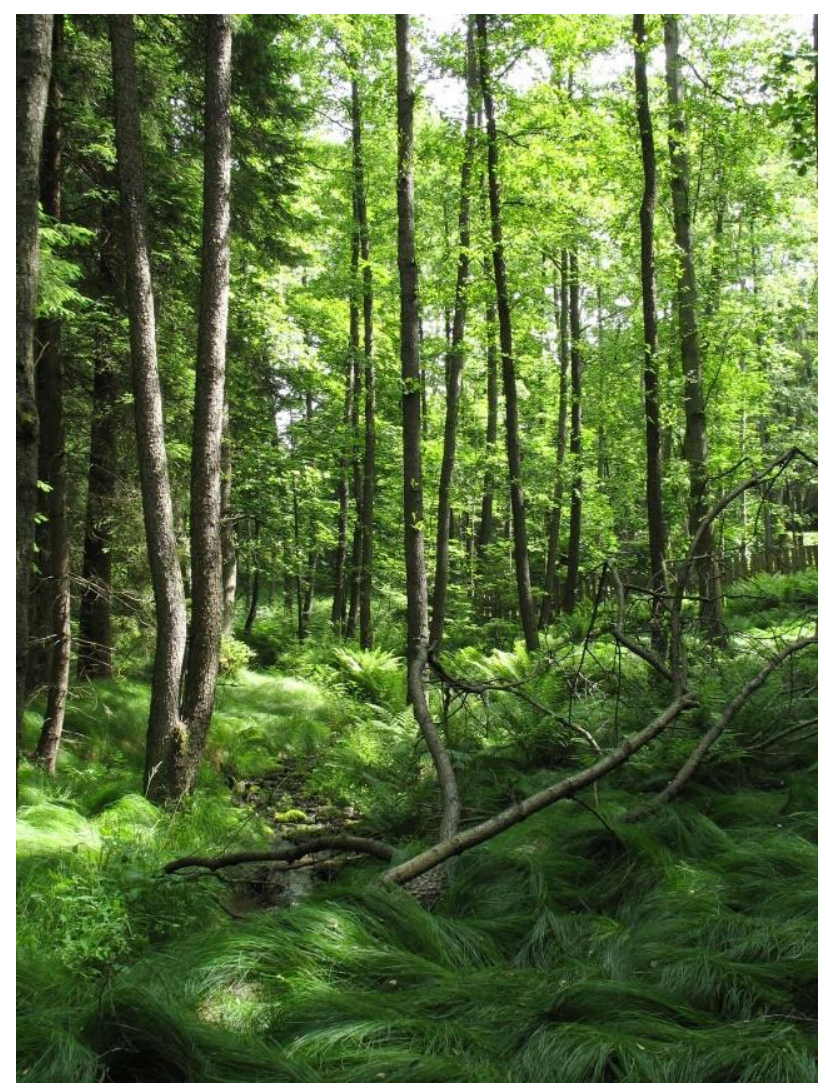

Fig 13: Vlčí potok Brook env. Brtníky (Loc. 48), photo by P. Chvojka.

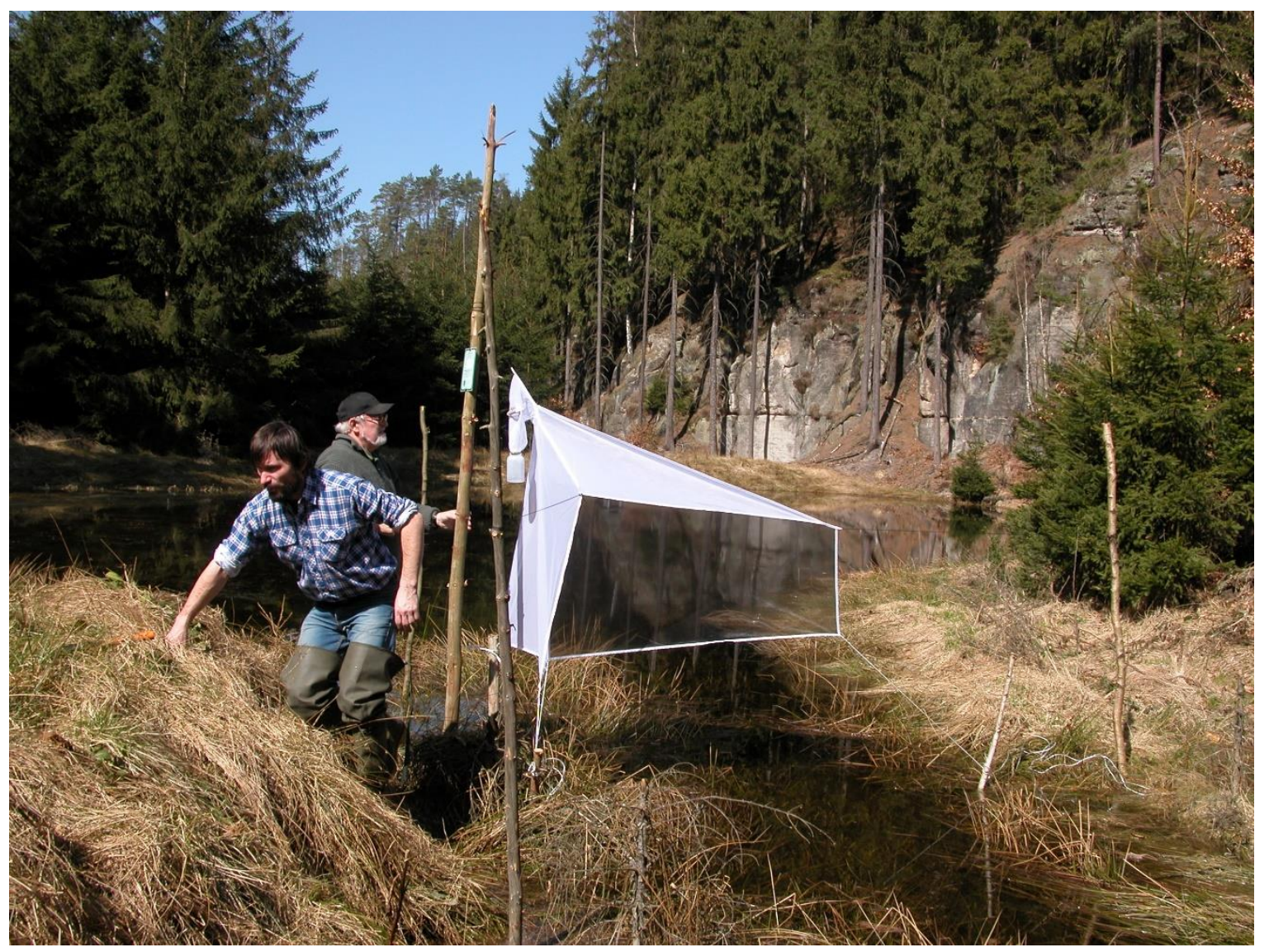

Fig 14: Zadní Jetřichovice (swamps), Loc. 52 - instalation of Malaise trap by P. Chvojka and J. Ježek (hind person), photo by M. Trýzna. 


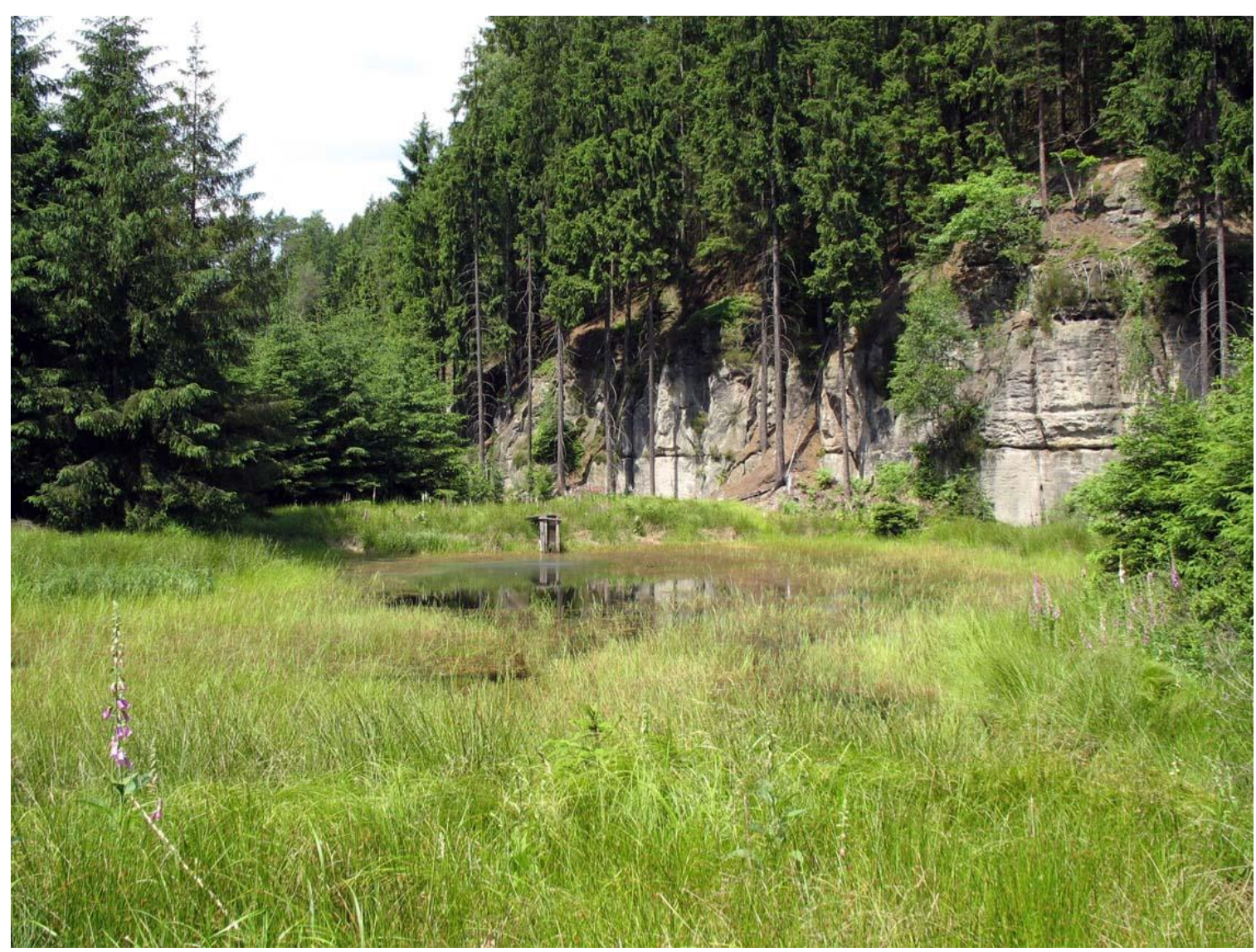

Fig 15: Zadní Jetřichovice (pond), Loc. 52, photo by P. Chvojka.

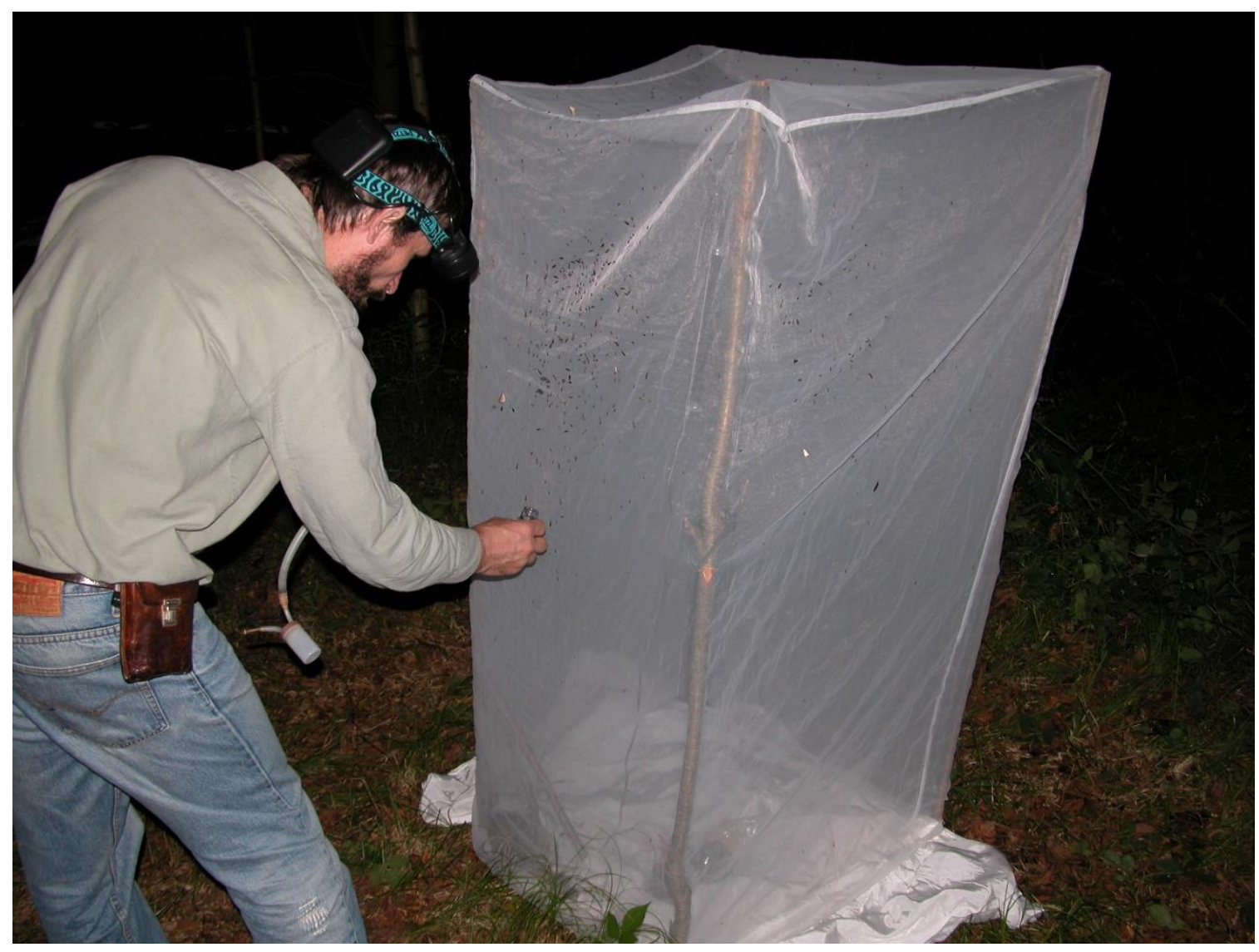

Fig 16: Zadní Jetrrichovice, light equipment for night collecting of insects used by P. Chvojka, Loc. 52, photo by M. Trýzna. 


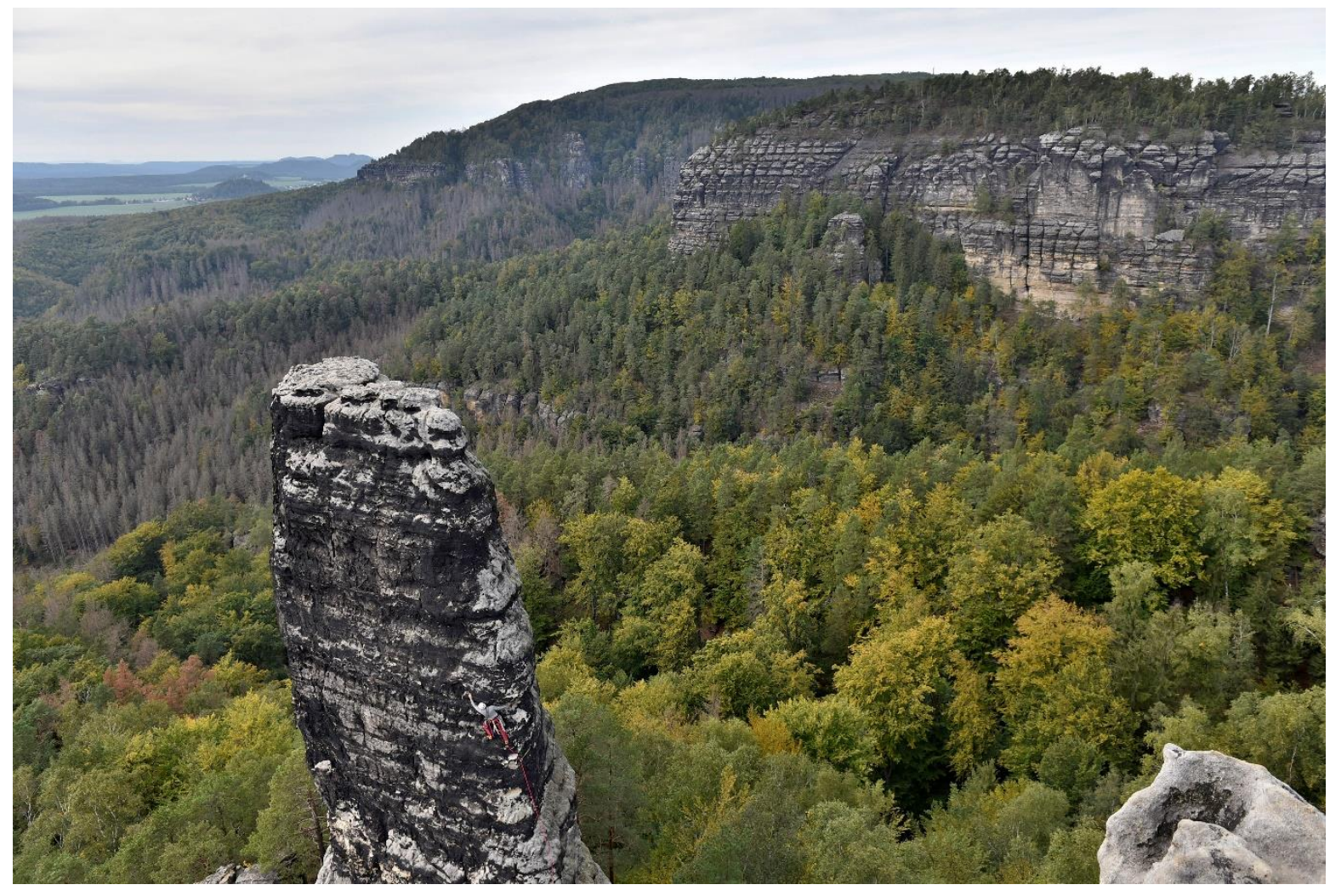

Fig 17: Interesting articulated geomorphology of the vicinity of Hřensko: Malý pravčický kužel Cone, rocky tower, photo by J. Preclík.

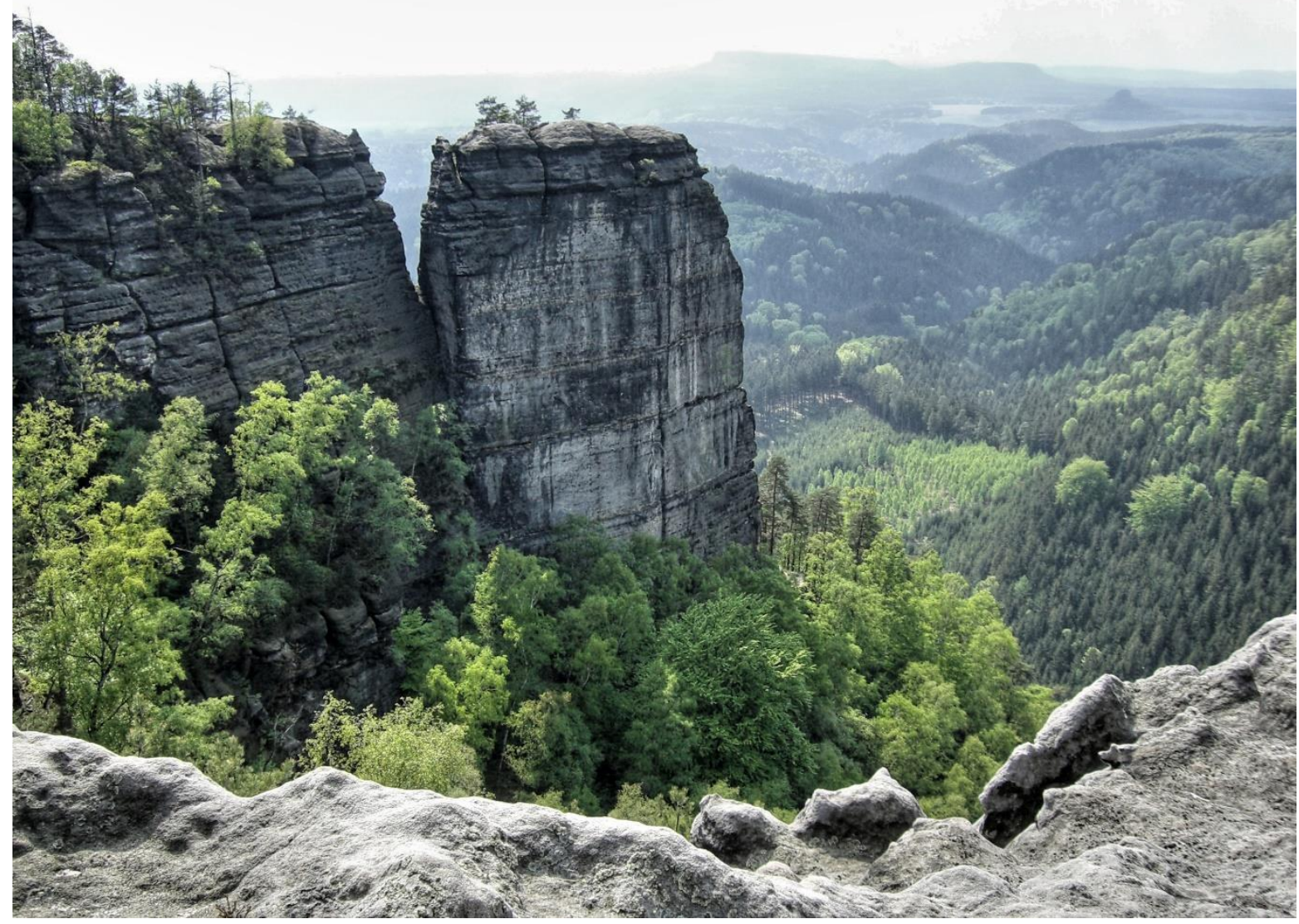

Fig 18: Rocky massivity of the environment of Hřensko, photo by Z. Vařilová. 

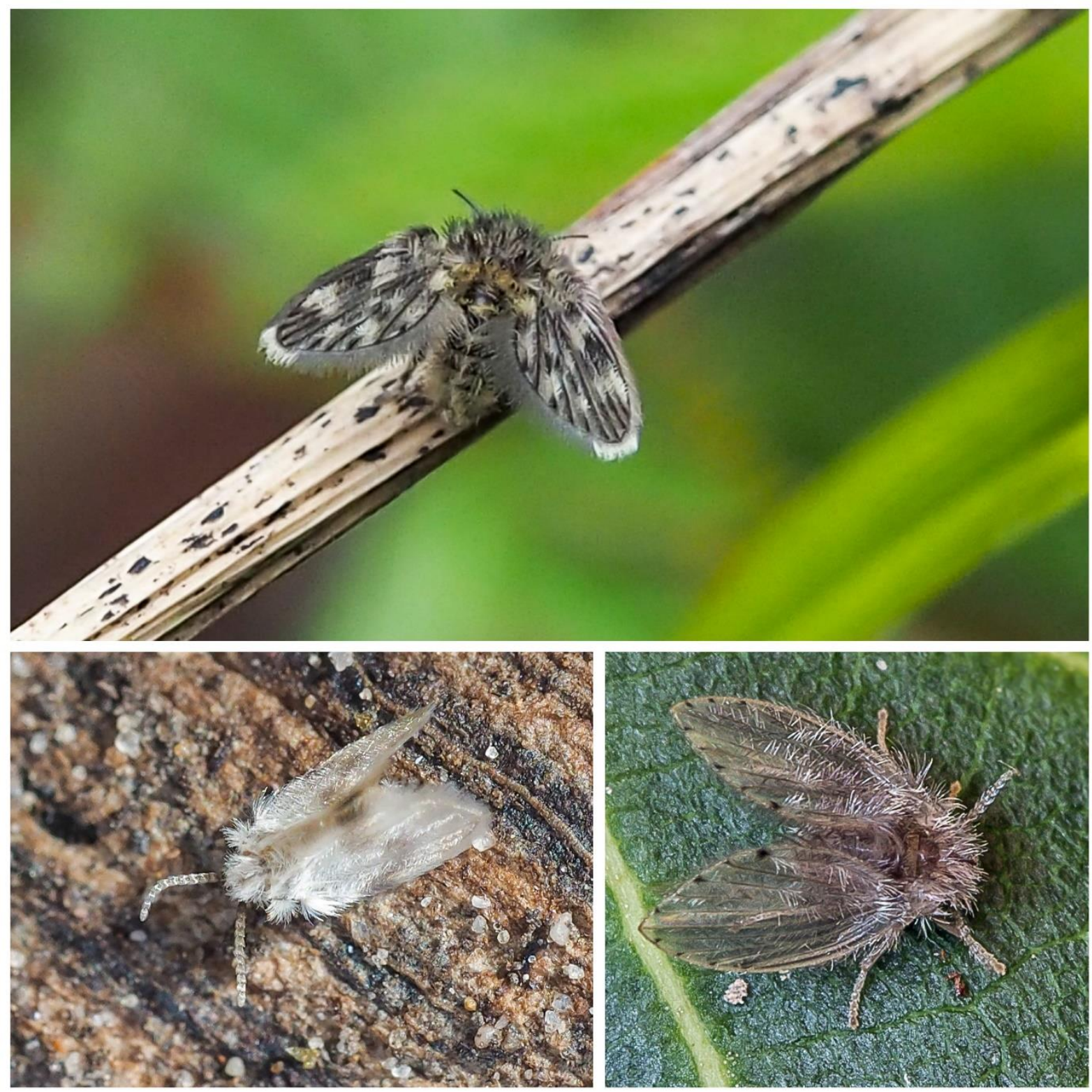

Fig 19: The members of the subfamily Psychodinae (Psychodidae, Diptera), photos by M. Polášek and R. Cáfal.

\section{Summary of the results and conclusion}

The psychodids fauna (Fig. 19) from the northern Hercynian Mountains and adjacent localities are presented. Altogether, 88 species were found, 20 of which were classified in the national Red List 2005 of threatened invertebrates and 14 of which are nationally scarce and suitable for subsequent monitoring.

The most species-rich localities include the following: site 30 (46 species), site 51 (40 species) and site 52 (41 species) (these sites were mostly frequently sampled using various intensive sampling methods). On the other hand, the localities with the lowest species diversity (usually with a low intensity of random sampling) were sites with just one species (sites 24, 39, 41, 43) and with two species (sites 1, 13, 16, 28, 50), see Tab. 1.

The most common species in the studied localities include $P$. trivialis (33 sites), P. (P.) blandula (22 sites), U. fuliginosa (21 sites) and S. labeculosus (20 sites). 
The most important localities in the sense of threatened moth flies (Ježek 2005) are:

- Three localities where three CR species and one EN are included: Hadí pramen Spring; Jetřichovice, Jetřichovická Bělá Brook; Krásná Lípa, pond.

- One locality with two CR, two EN, one VU and four NS - Zadní Jetřichovice.

- Four localities where two CR and one EN are always included and sometimes additionally VU or NS: Nad Edmundovou soutěskou Gulch (2 CR, 1 EN, 1 NS), Ponova louka Meadow (2 CR, 1 EN), Pryskřričný důl Valley (2 CR, 1 EN, 1 VU, 4 NS), Zadní Doubice - Křinice River (2 CR, 1 EN, 2 VU, 3 NS).

- Important localities as well are meanders of the Chřibská Kamenice River (1 CR, 1 EN, 2 VU, 3 NS), Růžovský vrch Hill (1 CR, 1 EN, 4 NS) and Vlčí potok Brook (1 CR, 1 EN, 3 NS). Twenty-seven sites (see Table 1) represent interesting localities with lesser numbers of threatened species.

Table 1: List of localities with recorded species.

\begin{tabular}{|c|c|c|}
\hline 1 & $\begin{array}{l}\text { Between Dolský mlýn } \\
\text { Mill and Královský smrk } \\
\text { Spruce }\end{array}$ & chvojkai (VU), fallax \\
\hline 2 & $\begin{array}{l}\text { Between Doubice and } \\
\text { Dolní Chřibská }\end{array}$ & blandula, fallax, nielseni (NS), trivialis \\
\hline 3 & $\begin{array}{l}\text { Between Jetřichovice and } \\
\text { Starý mlýn Mill } \\
\end{array}$ & $\begin{array}{l}\text { gressicus, labeculosa (EN), hirtella, albipennis, zetterstedti, ocellaris, } \\
\text { trivialis }\end{array}$ \\
\hline 4 & $\begin{array}{l}\text { Between Vlčí Hora and } \\
\text { Brtníky }\end{array}$ & valachica, labeculosa (EN), trivialis, fuliginosa \\
\hline 5 & $\begin{array}{l}\text { Between Vysoká Lípa and } \\
\text { Jetřichovice }\end{array}$ & andrenipes (CR), ocellaris, blandula, fuliginosa \\
\hline 6 & Bílý potok Brook & $\begin{array}{l}\text { andrenipes (CR), obscura, lucifugus, hirtella, lobata, brevicornis, } \\
\text { albipennis, satchelli, zetterstedti, grisescens, phalaenoides, cinerea, } \\
\text { gemina, minuta, trinodulosa, alternata, setigera, blandula, trivialis }\end{array}$ \\
\hline 7 & Brtnický most Bridge & $\begin{array}{l}\text { polyascoidea, hirtella, lobata, brevicornis, albipennis, erminea, satchelli, } \\
\text { zetterstedti, grisescens, phalaenoides, cinerea, gemina, minuta, } \\
\text { trinodulosa, alternata, setigera, manicata, fallax, nielseni (NS), trivialis, } \\
\text { nigricauda (CR), cognata }\end{array}$ \\
\hline 8 & $\begin{array}{l}\text { Brtnický potok Brook env. } \\
\text { Brtníky }\end{array}$ & $\begin{array}{l}\text { notabilis, gressica, silvaticus (VU), brevicornis, albipennis, satchelli, } \\
\text { grisescens, phalaenoides, cinerea, gemina, itoco (NS), trinodulosa, } \\
\text { chvojkai (VU), illiesi (NS), manicata, pyrenaica (NS), stavniensis, } \\
\text { unispinosa, ocellaris, blandula, fallax, pseudexquisita, trivialis, cognata, } \\
\text { fuliginosa }\end{array}$ \\
\hline 9 & $\begin{array}{l}\text { Brtníky env. } \\
\text { Mikulášovice, Brtnický } \\
\text { potok Brook }\end{array}$ & $\begin{array}{l}\text { soleata, valachica, integella }(\mathrm{CR}), \text { labeculosa }(\mathrm{EN}), \text { blandula, mutua, } \\
\text { trivialis, fuliginosa }\end{array}$ \\
\hline 10 & Brtníky x Mikulášovice & mutua, trivialis, fuliginosa \\
\hline 11 & Dolský mlýn Mill & $\begin{array}{l}\text { hygrophila, valachica, polyascoidea, labeculosa (EN), hirtella, lobata, } \\
\text { albipennis, satchelli, zetterstedti, grisescens, phalaenoides, uniformata, } \\
\text { cinerea, gemina, itoco (NS), minuta, trinodulosa, lativentris, setigera, } \\
\text { dalii, longicorniculatus (NS), ocellaris, blandula, nielseni (NS), trivialis, } \\
\text { cognata }\end{array}$ \\
\hline 12 & Doubice & $\begin{array}{l}\text { hygrophila, soleata, valachica, integella (CR), zetterstedti, blandula, } \\
\text { trivialis, fuliginosa }\end{array}$ \\
\hline 13 & $\begin{array}{l}\text { Ferdinandova soutěska } \\
\text { Gulch }\end{array}$ & blandula, fallax \\
\hline 14 & Hadí pramen Spring & $\begin{array}{l}\text { obscura, lobata, erminea, cinerea, gemina, minuta, pseudexquisita, } \\
\text { cubitospinosa }(\mathrm{EN}), \text { mutua, rotunda }(\mathrm{CR}), \text { hibernica }(\mathrm{CR}), \text { cognata, } \\
\text { fuliginosa, undulata }(\mathrm{CR})\end{array}$ \\
\hline
\end{tabular}




\begin{tabular}{|c|c|c|}
\hline 15 & Janov & cinerea, gemina, minuta, mutua, rotunda (CR), fuliginosa \\
\hline 16 & $\begin{array}{l}\text { Jetřichovice - swimming } \\
\text { pool }\end{array}$ & fallax, trivialis \\
\hline 17 & $\begin{array}{l}\text { Jetřichovice, Jetřichovická } \\
\text { Bělá Brook }\end{array}$ & $\begin{array}{l}\text { soleata, ellisi }(\mathrm{CR}), \text { longicornis, pseudolongicornis }(\mathrm{CR}) \text {, serbica }(\mathrm{CR}), \\
\text { auriculata, carthusiana, labeculosa }(\mathrm{EN}), \text { alternata, ocellaris, trivialis, } \\
\text { fuliginosa }\end{array}$ \\
\hline 18 & Kopec nr. Brtníky & $\begin{array}{l}\text { longicornis, pseudolongicornis (CR), polyascoidea, auriculata, cinerea, } \\
\text { ocellaris, blandula, trivialis, fuliginosa }\end{array}$ \\
\hline 19 & Krásná Lípa, brook & $\begin{array}{l}\text { soleata, longicornis, carthusiana, labeculosa (EN), blandula, mutua, } \\
\text { trivialis, fuliginosa }\end{array}$ \\
\hline 20 & Krásná Lípa, pond & $\begin{array}{l}\text { valachica, longicornis, pseudolongicornis (CR), serbica (CR), integella } \\
\text { (CR), labeculosa (EN), ocellaris, mutua, trivialis }\end{array}$ \\
\hline 21 & Křinice River & $\begin{array}{l}\text { bezzii (NS), andrenipes (CR), hassiaca (NS), polyascoidea, obscura, } \\
\text { hirtella, lobata, albipennis, erminea, satchelli, grisescens, phalaenoides, } \\
\text { cinerea, gemina, minuta, trinodulosa, blandula, trivialis }\end{array}$ \\
\hline 22 & Limberk & auriculata, lobata, satchelli, gemina, trivialis \\
\hline 23 & $\begin{array}{l}\text { Meanders of Chřibská } \\
\text { Kamenice River }\end{array}$ & $\begin{array}{l}\text { strobli (VU), valachica, falcariformis (NS), polyascoidea, auriculata, } \\
\text { gressica, labeculosa (EN), silvaticus (VU), hirtella, buxtoni (NS), lobata, } \\
\text { brevicornis, albipennis, erminea, satchelli, zetterstedti, grisescens, } \\
\text { crassipennis, phalaenoides, uniformata, cinerea, gemina, itoco (NS), } \\
\text { minuta, trinodulosa, alternata, lativentris, setigera, manicata, ocellaris, } \\
\text { blandula, fallax, nubila, trivialis, nigricauda (CR), fuliginosa }\end{array}$ \\
\hline 24 & Mezní Louka & trivialis \\
\hline 25 & $\begin{array}{l}\text { Mikulášovice - upper } \\
\text { station }\end{array}$ & $\begin{array}{l}\text { auriculata, labeculosa (EN), obscura, phalaenoides, cinerea, ocellaris, } \\
\text { mutua, trivialis, fuliginosa }\end{array}$ \\
\hline 26 & Mlýny & $\begin{array}{l}\text { tonnoiri }(\mathrm{CR}), \text { rothschildi }(\mathrm{NS}), \text { brevicornis, albipennis, satchelli, } \\
\text { zetterstedti, grisescens, phalaenoides, cinerea, gemina, minuta, setigera, } \\
\text { hibernica }(\mathrm{CR}), \text { fuliginosa }\end{array}$ \\
\hline 27 & $\begin{array}{l}\text { Nad Edmundovou } \\
\text { soutěskou Gulch }\end{array}$ & $\begin{array}{l}\text { silacea, tonnoiri (CR), labeculosa }(\mathrm{EN}), \text { lobata, satchelli, gemina, } \\
\text { trinodulosa, longicorniculatus }(\mathrm{NS}), \text { ocellaris, blandula, rotunda }(\mathrm{CR})\end{array}$ \\
\hline 28 & $\begin{array}{l}\text { Pavlínino údolí Valley } \\
\text { env. Jetřichovice }\end{array}$ & blandula, fallax \\
\hline 29 & Ponova louka Meadow & $\begin{array}{l}\text { urbica }(\mathrm{CR}), \text { polyascoidea, carthusiana, labeculosa }(\mathrm{EN}), \text { hirtella, } \\
\text { lobata, brevicornis, albipennis, satchelli, grisescens, phalaenoides, } \\
\text { gemina, minuta, mycophila, trinodulosa, setigera, dalii, trivialis, rotunda } \\
(\mathrm{CR})\end{array}$ \\
\hline 30 & Pryskyřičný důl Valley & $\begin{array}{l}\text { andrenipes (CR), hygrophila, soleata, valachica, acuminata, laminata } \\
\text { (CR), ustulata, polyascoidea, auriculata, gressica, labeculosa (EN), } \\
\text { obscura, hirtella, lobata, brevicornis, albipennis, erminea, satchelli, } \\
\text { sigma, zetterstedti, grisescens, phalaenoides, uniformata, cinerea, } \\
\text { gemina, itoco (NS), minuta, mycophila, trinodulosa, alternata, } \\
\text { lativentris, setigera, chvojkai (VU), illiesi (NS), longispinosa (NS), } \\
\text { manicata, stavniensis, unispinosa, subneglecta, blandula, fallax, nielseni } \\
\text { (NS), mutua, trivialis, cognata, fuliginosa }\end{array}$ \\
\hline 31 & $\begin{array}{l}\text { Pryskyřičný důl Valley - } \\
\text { peat bogs }\end{array}$ & $\begin{array}{l}\text { rothschildi (NS), lobata, brevicornis, albipennis, satchelli, grisescens, } \\
\text { phalaenoides, cinerea, gemina, itoco (NS), minuta, trinodulosa, } \\
\text { alternata, setigera, nielseni (NS) }\end{array}$ \\
\hline 32 & Růžovský vrch Hill & $\begin{array}{l}\text { silacea, septentrionalis }(\mathrm{NS}), \text { rothschildi }(\mathrm{NS}), \text { auriculata, carthusiana, } \\
\text { gressica, labeculosa (EN), hirtella, lobata, albipennis, satchelli, } \\
\text { zetterstedti, grisescens, crassipennis, phalaenoides, cinerea, gemina, } \\
\text { itoco (NS), minuta, trinodulosa, alternata, setigera, dalii, } \\
\text { longicorniculatus (NS), ocellaris, subneglecta, blandula, mutua, } \\
\text { palustris, trivialis, cognata, fuliginosa, undulata (CR) }\end{array}$ \\
\hline 33 & Rybniště env. Krásná Lípa & $\begin{array}{l}\text { denticulatus, auriculata, integella (CR), humerale, phalaenoides, } \\
\text { blandula, fallax, nubila, trivialis }\end{array}$ \\
\hline
\end{tabular}




\begin{tabular}{|c|c|c|}
\hline 34 & $\begin{array}{l}\text { Rynartice - Weidlichova } \\
\text { kaple Chapel }\end{array}$ & $\begin{array}{l}\text { hygrophila, soleata, carthusiana, gressica, zetterstedti, cinerea, ocellaris, } \\
\text { blandula, fallax, trivialis }\end{array}$ \\
\hline 35 & Severák & $\begin{array}{l}\text { auriculata, labeculosa }(\mathrm{EN}), \text { albipennis, erminea, cinerea, gemina, } \\
\text { minuta, unispinosa, dalii, ocellaris, blandula, mutua, trivialis, fuliginosa }\end{array}$ \\
\hline 36 & $\begin{array}{l}\text { Sněžná nr. Krásná Lípa } \\
\text { (brook) }\end{array}$ & $\begin{array}{l}\text { ellisi }(\mathrm{CR}), \text { longicornis, pseudolongicornis }(\mathrm{CR}) \text {, auriculata, albipennis, } \\
\text { fallax, trivialis }\end{array}$ \\
\hline 37 & $\begin{array}{l}\text { Srbská Kamenice (north- } \\
\text { eastern part) }\end{array}$ & $\begin{array}{l}\text { longicornis, prikryli, integella (CR), gressica, humerale, pyrenaica, } \\
\text { ocellaris, mutua, trivialis }\end{array}$ \\
\hline 38 & $\begin{array}{l}\begin{array}{l}\text { Srbská Kamenice } \\
\text { (western part) }\end{array} \\
\end{array}$ & $\begin{array}{l}\text { soleata, integella }(\mathrm{CR}), \text { labeculosa }(\mathrm{EN}), \text { hirtella, satchelli, } \\
\text { phalaenoides, mutua, trivialis }\end{array}$ \\
\hline 39 & $\begin{array}{l}\text { Srbská Kamenice (a farm } \\
\text { of cattle) }\end{array}$ & pusilla (NS) \\
\hline 40 & Starý mlýn Mill & unispinosa, ocellaris, fallax \\
\hline 41 & Suchá Bělá Brook & hirtella \\
\hline 42 & Suchá Bělá, pond & $\begin{array}{l}\text { silacea, hygrophila, procera, ustulata, polyascoidea, gressica, hirtella, } \\
\text { lobata, brevicornis, albipennis, satchelli, zetterstedti, grisescens, } \\
\text { phalaenoides, uniformata, cinerea, gemina, minuta, mycophila, } \\
\text { trinodulosa, alternata, lativentris, setigera, dalii, ocellaris, trivialis }\end{array}$ \\
\hline 43 & Šluknov & lucifugus \\
\hline 44 & Šluknov - údolí Valley & ocellaris, nubila, pilularia, trivialis, fuliginosa \\
\hline 45 & Tokáň & auriculata, albipennis, trivialis \\
\hline 46 & Eustach & $\begin{array}{l}\text { lobata, brevicornis, satchelli, grisescens, phalaenoides, cinerea, gemina, } \\
\text { itoco (NS), minuta, mycophila, trinodulosa, setigera, fuliginosa }\end{array}$ \\
\hline 47 & Vlčí Hora - Zahrady & labeculosa (EN), ocellaris, mutua, fuliginosa \\
\hline 48 & Vlčí potok Brook & $\begin{array}{l}\text { auriculata, labeculosa }(\mathrm{EN}), \text { obscura, lucifugus, hirtella, lobata, } \\
\text { brevicornis, albipennis, satchelli, grisescens, crassipennis, phalaenoides, } \\
\text { cinerea, gemina, itoco (NS), minuta, trinodulosa, alternata, lativentris, } \\
\text { setigera, manicata, matthesi, stavniensis, unispinosa, longicorniculatus } \\
\text { (NS), ocellaris, splendidus }(\mathrm{NS}), \text { subneglecta, blandula, fallax, mutua, } \\
\text { nubila, pilularia, trivialis, rotunda (CR), pulchra, cognata, fuliginosa }\end{array}$ \\
\hline 49 & $\begin{array}{l}\text { Všemily env. Srbská } \\
\text { Kamenice }\end{array}$ & lucifugus, mиtua, trivialis, fuliginosa \\
\hline 50 & Vysoká Lípa & andrenipes (CR), trivialis \\
\hline 51 & $\begin{array}{l}\text { Zadní Doubice (Křinice } \\
\text { River) }\end{array}$ & $\begin{array}{l}\text { andrenipes (CR), valachica, polyascoidea, labeculosa (EN), lucifugus, } \\
\text { silvaticus (VU), hirtella, lobata, brevicornis, albipennis, erminea, } \\
\text { satchelli, zetterstedti, grisescens, crassipennis, phalaenoides, uniformata, } \\
\text { cinerea, gemina, itoco (NS), minuta, trinodulosa, alternata, lativentris, } \\
\text { setigera, chvojkai (VU), longispinosa (NS), unispinosa, } \\
\text { longicorniculatus (NS), ocellaris, splendidus (NS), subneglecta, } \\
\text { blandula, fallax, pseudexquisita, pilularia, trivialis, nigricauda (CR), } \\
\text { pulchra, cognate }\end{array}$ \\
\hline 52 & Zadní Jetřichovice & $\begin{array}{l}\text { urbica }(\mathrm{CR}), \text { andrenipes }(\mathrm{CR}), \text { ustulata, polyascoidea, gressica, } \\
\text { labeculosa }(\mathrm{EN}), \text { humerale, lucifugus, hirtella, buxtoni (NS), lobata, } \\
\text { brevicornis, albipennis, erminea, satchelli, zetterstedti, grisescens, } \\
\text { crassipennis, phalaenoides, cinerea, gemina, itoco (NS), minuta, } \\
\text { mycophila, trinodulosa, alternata, lativentris, setigera, chvojkai (VU), } \\
\text { manicata, pyrenaica, stavniensis, unispinosa, longicorniculatus (NS), } \\
\text { ocellaris, splendidus (NS), subneglecta, blandula, fallax, rivularis (EN), } \\
\text { trivialis }\end{array}$ \\
\hline
\end{tabular}


An overview of the temporal and global geographical distribution of recorded species is summarized in Table 2. A total of 34 species were recorded from among the threatened moth flies (in detail: critically endangered species CR (13 species), endangered species EN (4 species), vulnerable species VU (3 species), thus far without Red status are eight species of nationally scarce NS (14 species)).

From the viewpoint of temporal distribution, 13 species were collected from May until October (v-x); the remaining species were limited to one or more months. For more details, see Tab. 2.

From the perspective of geographical distribution, the following groups of species were recorded: Central European - CEU (4 ssp.), Cosmopolitan - COS (5), European - EUR (38), European, penetrating into Transcaucasia - EUR* (14), Eurosiberian - EUS (5), Holarctic HOL (8), Palaearctic - PAL (6), Submediterranean - SBM (1).

Table 2: An updated systematic list of 88 species.

\begin{tabular}{|c|c|c|c|}
\hline Species & distribution & conservation & total occurrence \\
\hline Sycorax silacea Haliday in Curtis, 1839 & EUR & & v-vi \\
\hline Sycorax tonnoiri Jung, 1954 & EUR & $\mathrm{CR}$ & vi-vii \\
\hline Trichomyia urbica Haliday in Curtis, 1839 & EUR* & CR & vi \\
\hline Katamormia bezzii (Salamanna, 1983) & EUR & NS & vi \\
\hline Katamormia strobli Ježek, 1986 & EUR & VU & vi \\
\hline Oomormia andrenipes (Strobl, 1910) & EUR & $\mathrm{CR}$ & vi-vii \\
\hline Jungiella (Jungiella) hassiaca Wagner, 1993 & EUR & NS & \\
\hline Jungiella (Jungiella) hygrophila Ježek, 1987 & EUR & & vi \\
\hline Jungiella (Jungiella) septentrionalis Krek, 1979 & EUR & NS & vi \\
\hline Jungiella (Jungiella) soleata (Walker, 1856) & EUR* & & vi \\
\hline Jungiella (Jungiella) valachica (Vaillant, 1963) & EUR & & vi-vii \\
\hline Jungiella (Psychocha) acuminata (Szabó, 1960) & EUR & & vi-vii \\
\hline Jungiella (Psychocha) laminata (Szabó, 1960) & CEU & CR & vi \\
\hline Jungiella (Psychocha) procera Krek, 1971 & EUR & CR & vi \\
\hline Lepiseodina rothschildi (Eaton, 1912) & EUR & NS & vi \\
\hline Panimerus denticulatus Krek, 1971 & EUR* & & vi \\
\hline Panimerus falcariformis Wagner, 1977 & $\mathrm{CEU}$ & NS & vi \\
\hline Panimerus notabilis (Eaton, 1893) & EUR* & & vi \\
\hline Parajungiella ellisi (Withers, 1987) & EUS & $\mathrm{CR}$ & vi \\
\hline Parajungiella longicornis (Tonnoir, 1919) & EUS & & v-vi \\
\hline Parajungiella prikryli Ježek, 1999 & CEU & VU & $\mathrm{v}$ \\
\hline Parajungiella pseudolongicornis (Wagner, 1975) & EUR & CR & vi \\
\hline Parajungiella serbica (Krek, 1985) & EUR* & $\mathrm{CR}$ & vi \\
\hline
\end{tabular}




\begin{tabular}{|c|c|c|c|}
\hline Paramormia (Duckhousiella) ustulata (Walker, 1856) & HOL & & vi-ix \\
\hline Paramormia (Paramormia) polyascoidea $($ Krek, 1971) & EUS & & vi-ix \\
\hline Peripsychoda auriculata (Haliday in Curtis, 1839) & EUR* & & vi-vii \\
\hline Psycmera integella (Jung, 1956) & EUS & CR & v-vi \\
\hline Seoda carthusiana (Vaillant, 1972) & EUR & & v-vi \\
\hline Seoda gressica (Vaillant, 1972) & EUR & & v-vi \\
\hline Seoda labeculosa (Eaton, 1893) & EUR & $\mathrm{EN}$ & v-vi \\
\hline Feuerborniella obscura (Tonnoir, 1919) & EUR* & & vi-viii \\
\hline Philosepedon humerale (Meigen, 1818) & PAL ? & & v-vi \\
\hline Threticus lucifugus (Walker, 1856) & EUR & & $\mathrm{v}-\mathrm{x}$ \\
\hline Threticus silvaticus Ježek, 1985 & CEU & VU & vi-vii \\
\hline Trichopsychoda hirtella (Tonnoir, 1919) & EUR & & v-viii \\
\hline Apsycha pusilla (Tonnoir, 1922) & HOL & NS & \\
\hline Chodopsycha buxtoni (Withers, 1988) & EUR & NS & viii-ix \\
\hline Chodopsycha lobata (Tonnoir, 1940) & $\operatorname{COS}$ & & vi-ix \\
\hline Copropsychoda brevicornis (Tonnoir, 1940) & PAL & & $v-x$ \\
\hline Logima albipennis (Zetterstedt, 1850) & COS & & $v-x$ \\
\hline Logima erminea (Eaton, 1893) & PAL & & vi-ix \\
\hline Logima satchelli (Quate, 1955) & HOL & & $v-x$ \\
\hline Logima sigma (Kincaid, 1899) & COS? & & vi \\
\hline Logima zetterstedti Ježek, 1983 & COS? & & vi-viii \\
\hline Psycha grisescens (Tonnoir, 1922) & PAL ? & & $\mathrm{v}-\mathrm{x}$ \\
\hline Psychoda crassipennis Tonnoir, 1940 & EUR & & v-vi \\
\hline Psychoda phalaenoides (Linnaeus, 1758) & $\mathrm{HOL}$ & & $\mathrm{v}-\mathrm{x}$ \\
\hline Psychoda uniformata Haseman, 1907 & HOL & & $\mathrm{v}-\mathrm{x}$ \\
\hline Psychodocha cinerea (Banks, 1894) & $\mathrm{COS}$ & & $\mathrm{v}-\mathrm{x}$ \\
\hline Psychodocha gemina (Eaton, 1904) & EUR* & & $\mathrm{v}-\mathrm{x}$ \\
\hline Psychodocha itoco (Tokunaga \& Komyo, 1955) & PAL ? & NS & vi-viii \\
\hline Psychodula minuta (Banks, 1894) & HOL & & $v-i x$ \\
\hline Psychomora mycophila (Vaillant, 1988) & EUR* & & vi-ix \\
\hline Psychomora trinodulosa (Tonnoir, 1922) & $\mathrm{HOL}$ & & $v-i x$ \\
\hline Tinearia alternata (Say, 1824) & $\mathrm{COS}$ & & vi-x \\
\hline Tinearia lativentris (Berdén, 1952) & HOL & & vii-x \\
\hline Ypsydocha setigera (Tonnoir, 1922) & HOL & & $\mathrm{v}-\mathrm{x}$ \\
\hline Berdeniella chvojkai Ježek, 1999 & CEU & VU & vi \\
\hline
\end{tabular}




\begin{tabular}{|c|c|c|c|}
\hline Berdeniella illiesi Wagner, 1973 & EUR & NS & vi \\
\hline Berdeniella longispinosa (Vaillant, 1958) & EUR & NS & vi \\
\hline Berdeniella manicata (Tonnoir, 1920) & EUR* & & v-viii \\
\hline Berdeniella matthesi (Jung, 1954) & EUR & & $\mathrm{v}$ \\
\hline Berdeniella pyrenaica Vaillant, 1976 & EUR & NS & vi \\
\hline Berdeniella stavniensis (Krek, 1969) & EUR & & vi \\
\hline Berdeniella unispinosa (Tonnoir, 1919) & EUR & & vi-vii \\
\hline Clytocerus (Boreoclytocerus) dalii (Eaton, 1893) & EUR & & v-viii \\
\hline Clytocerus (Boreoclytocerus) longicorniculatus Krek, 1987 & EUR & NS & $v-x$ \\
\hline Clytocerus (Boreoclytocerus) ocellaris (Meigen, 1804) & EUR & & v-ix \\
\hline $\begin{array}{l}\text { Clytocerus (Boreoclytocerus) splendidus Ježek \& Hájek, } \\
2007\end{array}$ & CEU & NS & vi-vii \\
\hline Parabazarella subneglecta (Tonnoir, 1922) & EUS & & v-ix \\
\hline Pericoma (Pachypericoma) blandula Eaton, 1893 & PAL & & v-ix \\
\hline Pericoma (Pachypericoma) fallax Eaton, 1893 & EUS & & vi-ix \\
\hline Pericoma (Pachypericoma) nielseni Kvifte, 2010 & EUR & NS & vi-viii \\
\hline Pericoma (Pericoma) pseudexquisita Tonnoir, 1940 & EUS & & vi \\
\hline Pneumia cubitospinosa (Jung, 1954) & EUR & EN & v-vi \\
\hline Pneumia mutua (Eaton, 1893) & EUR & & v-viii \\
\hline Pneumia nubila (Meigen, 1818) & EUR* & & v-viii \\
\hline Pneumia palustris (Meigen, 1804) & EUR* & & $\mathrm{v}$ \\
\hline Pneumia pilularia (Tonnoir, 1940) & EUR* & & $\mathrm{v}-\mathrm{x}$ \\
\hline Pneumia rivularis Berdén, 1954 & PAL & EN & vi \\
\hline Pneumia trivialis (Eaton, 1893) & EUR* & & $v-x$ \\
\hline Saraiella rotunda (Krek, 1970) & SBM & CR & $\mathrm{v}$ \\
\hline Szaboiella hibernica (Tonnoir, 1940) & EUR & $\mathrm{CR}$ & vi-vii \\
\hline Tonnoiriella nigricauda (Tonnoir, 1919) & EUR & $\mathrm{CR}$ & viii-x \\
\hline Tonnoiriella pulchra (Eaton, 1893) & EUR & & vi-vii \\
\hline Ulomyia cognata (Eaton, 1893) & EUR* & & v-viii \\
\hline Ulomyia fuliginosa (Meigen, 1804) & EUR & & v-ix \\
\hline Ulomyia undulata (Tonnoir, 1919) & EUR & $\mathrm{CR}$ & v-vi \\
\hline
\end{tabular}

Abbreviations: CEU - Central European, COS - Cosmopolitan, EUR - European, EUR* - European, penetrates to Transcaucasia, EUS - Eurosiberian, HOL - Holarctic, PAL - Palaearctic, SBM - Submediterranean; $\mathrm{CR}$ - critically endangered, EN - endangered, VU - vulnerable, NS - nationally scarce, the roman numerals v-x. - months indicating the occurrence of the species in the northern Hercynicum. 
In the Appendix, the last checklist (Ježek 2009c) is complemented by the faunistic results of Ježek et al. (2010, 2012, 2013, 2014), Ježek \& Omelková (2012), Omelková \& Ježek (2012a,b,c,), Oboňa \& Ježek (2012a,b, 2014), Šuláková et al. (2014), Tkoč et al. (2014), Kroča \& Ježek (2015, 2019), Dvorak et al. (2016), Oboňa \& Kozánek (2018) and Oboňa et al. (2021).

Changes in the nomenclature are added in Kvifte (2014) and Ježek et al. (2020).

Altogether, 183 species are listed in the present checklist: 178 in the Czech Republic (147 in Bohemia, 160 in Moravia) and 119 in Slovakia.

Acknowledgements: We thank to the large staff of the Management of České Švýcarsko NP, Labské pískovce PLA and Lužické hory PLA for their support of our research. We are obliged to P. Chvojka, J. Macek, H. Studničková and J. Kabelák (all National Museum Praha) for their help in the field and the sorting of insects in the laboratory. Thanks are due to R. Cáfal (photographer from www.nahuby.sk), M. Polášek (Farmaceutic Faculty of Hradec Králové), J. Preclík and Z. Vařilová (Municipal Museum of Ústí nad Labem) for their photographs of important localities and insects, and to Oldřich Holešinský (České Švýcarsko NP Administration) for the preparation of map documents. We would like to thank to P. Chvojka from our team who helped by providing constructive comments and improving the manuscript. The study was supported by the Ministry of Culture of the Czech Republic (DKRVO 2020-2023/5.I.c, National Museum, Prague, 00023272), by the EEA and Norway Grants funded by Iceland, Liechtenstein and Norway, and partly supported by the grant agency KEGA Project No. 005PU-4/2019 and by the Slovak Scientific Grant Agency, contract No. VEGA-1/0012/20.

\section{References}

Afzan H. \& Belquat B. (2016): Faunistic and bibliographical inventory of the Psychodinae moth-flies of North Africa (Diptera, Psychodidae). - ZooKeys 558: 119-145.

Blažej L. \& Trýzna M. (2007): Výsledky průzkumu kutilek (Hymenoptera: Spheciformes) iniciačního stádia sukcese spáleniště na Krkavčím kameni u Jetřichovic (NP České Švýcarsko). (Resultate der Untersuchung der Grabwespen (Hymenoptera: Spheciformes) im frühen Sukzessionsstadium der Brandstelle am Rabenstein bei Dittersbach im NLP České Švýcarsko). - Sborník Oblastního muzea v Mostě, Řada př́rodovědná 29/30: 117121.

Blažej L., Macek J. \& Trýzna M. (2016): Kutilky a vosovití (Hymenoptera: Aculeata: Spheciformes, Vespidae) chladných a inverzních biotopů v Národním parku České Švýcarsko. - Sborník Severočeského muzea, Přírodní vědy 34: 107-142.

Bogusch P., Blažej L., Trýzna M. \& Heneberg P. (2015): Forgotten role of fires in Central European forests: critical importance of early post-fire successional stages for bees and wasps (Hymenoptera: Aculeata). European Journal of Forest Research 134: 153-166.

Bojková J., Soldán T., Zahrádková S., Chvojka P. \& Trýzna M. (2010): Ephemeroptera and Plecoptera of the Bohemian Switzerland National Park, Czech Republic: species diversity and taxocenoses of sandstone watercourses. - Lauterbornia 70: 91-110.

Dvorak V., Hlavackova K., Kocisova A. \& Volf P. (2016): First record of Phlebotomus (Transphlebotomus) mascittii in Slovakia. - Parasite 23: 48.

Ehrendorfer F. \& Hamann U. (1965): Vorschläge zu einer floristischen Kartierung von Mitteleuropa. Berichte der Deutschen Botanischen Gesellschaft 78: 35-50.

Härtel H. (2013): Chráněná území Českého Švýcarska. Díl I. Úvod. České Švýcarsko. - Zpravodaj Správy Národního parku České Švýcarsko 12(2): 10-11.

- (2014): Chráněná území Českého Švýcarska. Díl III. Národní přírodní rezervace Růžák - České Švýcarsko. Zpravodaj Správy Národního parku České Švýcarsko 13(2): 10-11.

Holešinská J., Klitsch M., Marková I., Nagel R., Trýzna M. \& Vařilová Z. (2010): Komplexní monitoring stavu př́rodního prostředí na území Národního parku České Švýcarsko. - Ochrana př́rody 2: 1820.

Horák J., Loskotová T., Brestovský J., Klitsch M. \& Trýzna M. (2015): Možná největší výzkum živočichů na území NP Českého Švýcarska. - Listy Entomologického klubu při Labských pískovcích 15: 6-7.

Chvojka P., Hájek J., Ježek J. \& Macek J. (2010): Monitoring ohrožených druhů vybraných skupin hmyzu v Národním parku České Švýcarsko v letech 2008-2010. Závěrečná zpráva. 149 pp.

Ježek J. (1984): Taxonomic notes on Mormiini (Diptera, Psychodidae) from the High Tatra National Park. - Acta Entomologica Bohemoslovaca 81: 223-231.

- (1985): Contribution to the knowledge of a new subtribe Trichopsychodina (Diptera, Psychodidae) from Czechoslovakia. - Acta Musei Nationalis Pragae 40 B No.2, 1984: 65-92. 
- (1994): Catalogue of Holarctic and Afrotropical Mormiina End. (Diptera, Psychodidae, Psychodinae, Mormiini). - Časopis Národního Muzea, Řada př́rodovědná 162: 63-66.

- (1999): Moth flies (Diptera, Psychodidae) inhabiting wet extreme biotopes of the Sokolov open-cast coal mines and dumps, with descriptions of three new species from the Western Bohemia. - Acta Musei Nationalis Pragae, Series B, Historia Naturalis 54: 45-60.

- (2003): New faunistic data and check list of non Phlebotomine moth flies (Diptera, Psychodidae) from the Czech and Slovak Republics. - Časopis Národního Muzea, Řada př́rodovědná 162: 63-66.

- (2004): New and interesting moth flies (Diptera, Psychodidae) from protected and underestimated natural areas of the Czech Republic. - Časopis Národního Muzea, Řada přirodovědná 172: 121-132.

- (2005): Psychodidae (koutulovití). Pp. 259-261. In: Farkač J., Král D. \& Škorpík M. (eds): Červený seznam ohrožených druhů České republiky. Bezobratlí. Red list of threatened species in the Czech Republic. Invertebrates. Agentura ochrany př́rody a krajiny ČR, Praha, 758 pp.

- (2006a): Psychodidae. Faunistic records. Dipterologica Bohemoslovaca Vol. 13. - Acta Universitatis Carolinae Biologica 50 (1-2): 139-140.

- (2006b): Psychodidae (Diptera) of the Jeseníky Protected Landscape Area and its environs with descriptions of two new Berdeniella species from the Czech Republic. - Acta Entomologica Musei Nationalis Pragae 46: 151192.

- (2007): New records of moth flies (Diptera, Psychodidae) from Poland with description of Apsycha gen.nov. Acta zoologica Universitatis Comenianae (Bratislava) 47(2): 145-160.

- (2009a): Further new faunistic records of moth flies (Insecta, Diptera, Psychodidae) from the Czech Republic and Slovakia. - Folia Faunistica Slovaca 14(15): 101-105.

- (2009b): Psychodidae, pp. 89-92. In: Roháček J. \& Ševčík J. (eds): Diptera of the Pol’ana Protected Landscape Area - Biosphere Reserve (Central Slovakia). SNC SR, Admin. of the PLA - BR Pol'ana, Zvolen, 340 pp.

- (2009c): Psychodidae Newman, 1834. In: Jedlička L., Kúdela M. \& Stloukalová V. (eds): Checklist of Diptera of the Czech Republic and Slovakia, electronic version 2. Available from http://www.edvis.sk/ diptera2009/families/psychodidae.htm. Accessed 2.10.2021.

Ježek J., Barták M. \& Vaněk J. (2010): Koutulovití (Diptera, Psychodidae) vysokých poloh Krkonoš. Psychodidae (Diptera) of the high altitudes of the Krkonoše Mts. - Opera Corcontica 47: 265-273.

Ježek J., Chvojka P., Manko P. \& Oboňa J. (2017): Faunistic and bibliographical inventory of moth flies from Ukraine (Diptera, Psychodidae). - ZooKeys 693: 109-128.

Ježek J., Grootaert P., Lock K., Manko P. \& Oboňa, J. (2018): Moth flies (Diptera: Psychodidae) from the Belgian transition of the Atlantic to the Central European faunal zones. - Biodiversity \& Environment 10(2): 5-17.

Ježek J., Kubík Š. \& Barták M. (2005): Psychodidae. pp. 78-85. In: Barták M. \& Kubík Š. (eds.): Diptera of Podyjí National Park and its environs. Czech University of Life Sciences Prague, Faculty of Agrobiology, Food and Natural Resources, PowerPrint, Prague, $432 \mathrm{pp}$.

- (2013): Psychodidae (Diptera) of Vráž nr. Písek (Czech Republic), pp. 189-198. In: Kubík Š. \& Barták M. (eds): Proceedings of the „Workshop on biodiversity“, Jevany, 2.-3th July, 2013. ČZUP, 436 pp.

Ježek J., Lukáš J., Kvifte G.M. \& Oboňa J. (2012): New faunistic records of non-biting moth flies (Diptera: Psychodidae) from the Czech Republic and Slovakia. Nové faunistické nálezy koutulí (Diptera: Psychodidae) z České republiky a Slovenska. - Klapalekiana 48: 121-126.

Ježek J., Oboňa J., Grootaert P., Lock K., Manko P. \& Dekoninsk W. (2020): Review of two Tonnoir moth fly species, overlooked for a century (Diptera: Psychodidae: Psychodinae). - Acta Entomologica Musei Nationalis Pragae 60(2): 517-526.

Ježek J., Omelková M. \& Heřman P. (2014): Koutulovití (Psychodidae, Diptera) Českého krasu a přilehlých lokalit. Moth flies (Psychodidae, Diptera) of the Český kras/Bohemian Karst and neighbouring localities (Czech Republic). - Bohemia Centralis, Praha 32: 321-344.

Ježek J., Manko P. \& Oboňa J. (2020): Synopsis of the Psychodidae (Diptera) fauna of Bulgaria. - Zootaxa 4877(2): 201-240.

- (2021): Psychodidae (Diptera) of Azerbaijan and Georgia-faunistics with biodiversity notes. - ZooKeys 1049: $15-42$.

Ježek J., Oboňa J., Přikryl I. \& Mikátová B. (2019): Moth flies (Diptera: Psychodidae) of the western Hercynian mountains, Sokolov open-cast coal mines and dumps (Czech Republic). - Acta Musei Silesiae, Scientiae Naturales 67(3): 193-292.

Ježek J. \& Omelková M. (2007): Faunistic records from Czech Republic and Slovakia: Diptera, Psychodidae. - Acta zoologica Universitatis Comenianae (Bratislava) 47: 250-253.

- (2012): Moth flies (Diptera: Psychodidae) of the Bilé Karpaty Protected Landscape Area and Biosphere Reserve (Czech Republic). In: Malenovský, I., Kment, P. \& Konvička, O. (eds): Species inventories of selected insect groups in the Bile Karpaty Protected Landscape Area and Biosphere Reserve (Czech Republic). - Acta Musei Moraviae, Scientiae Biologicae, Brno, pp. 763-802. 
Ježek J. \& van Harten A. (2005): Further new taxa and little-known species of non-biting moth flies (Diptera, Psychodidae) from Yemen. - Acta Entomologica Musei Nationalis Pragae 45: 199-220.

- (2009): Order Diptera, Family Psychodidae. Subfamily Psychodinae (non-biting moth flies), pp. 686-711. In: van Harten A. (ed.): Arthropod Fauna of the United Arab Emirates, Vol. 2. Dar Al Ummah Printing, Publishing, Distribution and Advertising, Abu Dhabi, 786 pp.

Ježek J., Vonička P. \& Preisler J. (2008): Koutulovití (Diptera: Psychodidae) Jizerských hor a Frýdlantska. Psychodidae (Diptera) of the Jizerské hory Mts and Frýdlant region (northern Bohemia, Czech Republic). Sborník Severočeského Muzea, Př́rodní Vědy, Liberec 26: 129-151.

Ježek J. \& Yağci Ș. (2005): Common non-biting moth flies (Insecta, Diptera, Psychodidae) new to the fauna of Turkey. - Acta Parasitologica Turcica 29(3): 188-192.

Krek S. (1999): Psychodidae (Diptera Insecta) Balkanskog Poluotoka. Federacija Bosne I Hercegovine, Ministarstvo Obrazovanja, Nauke, Kulture I Sporta, Studentska Štamparija Univerziteta Sarajevo, Sarajevo, $417 \mathrm{pp}$.

Kroča J. \& Ježek J. (2015): Moth flies (Psychodidae: Diptera) of the Moravskoslezské Beskydy Mts and Podbeskydská pahorkatina Upland (Czech Republic). - Acta Musei Silesiae, Scientiae Naturales 64: 27-50.

- (2019): Moth flies (Psychodidae: Diptera) of the Moravskoslezské Beskydy Mts and Podbeskydská pahorkatina Upland (Czech Republic), II. - Acta Musei Silesiae, Scientiae Naturales 68: 201-232.

Kvifte G.M. (2014): Nomenclature and taxonomy of Telmatoscopus Eaton and Seoda Enderlein; with a discussion of parameral evolution in Paramormiini and Pericomaini (Diptera: Psychodidae, Psychodinae). - Zootaxa 3878(4): 390-400.

Kvifte G.M., Håland Ø. \& Andersen T. (2011): A revised checklist of Norwegian moth flies (Diptera, Psychodidae). - Norwegian Journal of Entomology 58: 180-188.

Morelli A. \& Biscaccianti A.B. (2021): New records of moth flies (Diptera Psychodidae) mainly from protected areas of peninsular Italy. - Redia 104: 111-123.

Oboňa J., Dvořak L., Dvořaková K., Ježek J., Kovács T., Murányi D., Slowinska I., Starý J., van der Weele R. \& Manko P. (2019): Faunistic records of some Diptera families from the Babia Góra massif in Poland. - Dipteron, Bulletin of the Dipterological Section of the Polish Entomological Society 35: 118-131.

Oboňa J. \& Ježek J. (2012a): First records of dendrolimnetic moth flies (Diptera: Psychodidae) from Slovakia. Prvonálezy dendrotelmových kútoviek (Diptera: Psychodidae) zo Slovenska. - Klapalekiana 48: 279-287.

- (2012b): Range expansion of the invasive moth midge Clogmia albipunctata (Williston, 1893) in Slovakia (Diptera: Psychodidae). - Folia Faunistica Slovaca 17(4): 387-391.

- (2014): Prodromus of moth flies (Diptera: Psychodidae) from Slovakia. - Acta Musei Silesiae, Scientiae Naturales 63: 193-251.

Oboňa J., Ježek J., Kanašová K. \& Manko P. (2021): Hiding in plain sight: new records and endangered flies (Diptera) from a tree-hole in an urban park (Prešov, Slovakia). - Acta Musei Silesiae, Scientiae Naturales 70: $75-81$

Oboňa J. \& Kozánek M. (2018): First record of Logima sigma (Kincaid, 1899) (Diptera: Psychodidae) from Slovakia. - Biodiversity \& Environment 10(2): 22-24.

Omelková M. \& Ježek J. (2012a): A new species of the genus Trichomyia (Diptera: Psychodidae) and new faunistic data on non-phlebotomine moth flies from the Podyjí NP and its surroundings (Czech Republic). Acta Musei Moraviae. Scientiae Biologicae 55(2): 505-533.

Omelková M. \& Ježek J. (2012b): Two new species of Pneumia Enderlein (Diptera, Psychodidae, Psychodinae) from the Palaearctic region. - Zootaxa 3180: 1-18.

Omelková M. \& Ježek J. (2012c): Two new species of Philosepedon Eaton (Diptera, Psychodidae, Psychodinae) from Europe, with comments on subgeneric classification. - Zootaxa 3275: 29-42.

Patzelt Z. (2011): Národní parky České republiky. Granit, 320 pp.

Pižl V., Starý J. \& Tajovský K. (2011): Monitoring diverzity půdní fauny v inverzních roklích NP České Švýcarsko. Zpráva za rok 2011, 10 pp.

Preisler J., Blažej L. \& Trýzna M. (2019): Lanýžkovití (Diptera: Heleomyzidae) Labských pískovců (severní Čechy). Heleomyzidae (Diptera) of the Elbe Sandstones (northern Bohemia, Czech Republic). - Sborník Severočeského Muzea, Př́rodní vědy 37: 125-146.

Pruner L. \& Míka P. (1996): Seznam obcí a jejich částí v České republice s čísly mapových polí pro sítové mapování fauny. List of settlements in the Czech Republic with associated map field codes for faunistic grid mapping system. - Klapalekiana 32 (Suppl.): 1-115.

Salmela J., Paasivirta L. \& Kvifte G.M. (2014): Checklist of the families Chaoboridae, Dixidae, Thaumaleidae, Psychodidae and Ptychopteridae (Diptera) of Finland. - ZooKeys 441: 37-46.

Soldán T., Zahrád ková S. \& Bojková J. (2008): Monitoring vodního hmyzu řádů Ephemeroptera, Plecoptera, Megaloptera a Neuroptera (vodní druhy) na vybraných lokalitách Národního parku České Švýcarsko (letní a podzimní aspekt 2008), 42 pp. (Biological Centre of the Academy of Sciences, Institute of Entomology) České Budějovice. 
- (2009): Monitoring vodního hmyzu řádů Ephemeroptera, Plecoptera, Megaloptera a Neuroptera (vodní druhy) NP České Švýcarsko: inventarizace a struktura taxocenóz vybraných lokalit, 48 pp.

Strejček J., Blažej L., Trýzna M., Škoda R. \& Bauer P. (2020): Fytofágní brouci Labských pískovců (Coleoptera: Chrysomeloidea, Curculionoidea). Phytophagous beetles of the Elbe Sandstones (Coleoptera: Chrysomeloidea, Curculionoidea). - Sborník Severočeského Muzea, Přírodní vědy 38: 63-201.

Szabó J. (1983): 10. család: Psychodidae - Lepkeszúnyogok. - Fauna Hungariae 156: 1-78.

Šuláková H., Gregor F., Ježek J. \& Tkoč M. (2014): Nová invaze do našich obcí a měst: koutule Clogmia albipunctata a problematika myiáz. - Živa 1/2014: 29-32.

Tkoč M., Pecharová M. \& Ježek J. (2014): Catalogue of the type specimens of Diptera deposited in the Department of Entomology, National Museum, Prague, Czech Republic, part 10. Moth Flies (Psychodidae). Acta Entomologica Musei Nationalis Pragae 54(2): 789-837.

Vaillant F. (1971-1983): 9d. Psychodidae - Psychodinae (not finished). In: Lindner E. (ed.): Die Fliegen der palaearktischen Region. Stuttgart. Vols. 287(1971): 1-48; 291(1972): 49-78; 292(1972): 79-108; 305(1974): 109-142; 310(1975): 143-182; 313(1977): 183-206; 317(1978): 207-238; 320(1979): 239-270; 326(1981): 271-310; 328(1983): 311-357.

Wagner R. (1990): Family Psychodidae. In: Soós A. (ed.): Catalogue of Palaearctic Diptera. Vol. 2. Psychodidae - Chironomidae. Akadémiai Kiadó, Budapest, pp. 11-65.

- (2018). Fauna Europaea: Psychodidae. In: de Jong H. (ed.): Fauna Europaea: Diptera Nematocera. Fauna Europaea version 2018. Available on: https://fauna-eu.org (accessed 21 October 2021).

Withers P. (1989a): Moth Flies. Diptera: Psychodidae. - Dipterists Digest 4: 1-83.

- (1989b): Some further records of Irish rot-hole moth flies (Diptera: Psychodidae), with a first record for Telmatoscopus rothschildii, with a figure of the male terminalia of that species. - Irish Naturalists' Journal 23(1): 16-17.

Zelený J. (1972): Návrh členění Československa pro faunistický výzkum. Entwurf einer Gliederung der Tschechoslowakei für Zwecke der faunistischen Forschung. - Zprávy Československé společnosti entomologické př̀ ČSAV 8: 3-16.

Authors' addresses: Jan Ježek, National Museum, Department of Entomology, Cirkusová 1740,

CZ - 19300 Praha 9 - Horní Počernice, Czech Republic.

E-mail: jan.jezek@o2active.cz

Jozef Oboňa, Peter Manko, Department of Ecology, Faculty of Humanities and Natural Sciences, University of Prešov, 17. novembra 1, SK-08116 Prešov, Slovakia.

E-mail: peter.manko@unipo.sk

Miloš Trýzna, Municipal Museum of Ústí nad Labem, Natural History Department, Masarykova 1000/3, CZ - 40001 Ústí nad Labem, Czech Republic; Mendel University in Brno, Faculty of Forestry and Wood Technology, Department of Forest Ecology, Zemědělská 3, CZ - 61300 Brno, Czech Republic.

E-mail: anthribidae@gmail.com

*Corresponding author: jozef.obona@unipo.sk 


\section{Appendix}

\section{New checklists of moth flies (Diptera: Psychodidae) of Czech Republic and Slovakia.}

\section{PHLEBOTOMINAE}

Phlebotomus Rondani, 1840

subg. Larroussius Nitzulescu, 1931

mascittii Grassi, $1908 \quad$ SK**

SYCORACINAE

Sycorax Haliday in Curtis, 1839

$\begin{array}{ll}\text { bicornua Krek, 1970 } & \text { CZ (B ) } \\ \text { popovi Ježek, 1990 } & \text { CZ ( M) } \\ \text { silacea Haliday in Curtis, 1839 } & \text { CZ (B M) SK } \\ \text { similis (Müller, 1927) } & \text { CZ (B M) } \\ \begin{array}{l}\text { slovaca Halgoš, 1975 } \\ \text { tonnoiri Jung, 1954 }\end{array} & \text { SK } \\ \end{array}$

TRICHOMYIINAE

tonnoiri Jung, 1954

Trichomyia Haliday in Curtis, 1839

hardeggensis Omelková \& Ježek, 2012

$\begin{array}{ll}\text { parvula Szabó, } 1960 & \mathrm{CZ}(\mathrm{M}) \\ \text { urbica } \text { Haliday in Curtis, } 1839 & \mathrm{CZ}(\mathrm{B} \mathrm{M}) \text { SK }\end{array}$

PSYCHODINAE

MORMIINI

BRUNETTIINA

Atrichobrunettia Satchell, 1953

subg. Mirousiella Vaillant, 1974

$\begin{array}{ll}\text { graeca Ježek \& Goutner, } 1993 & \\ & \mathrm{CZ}(\mathrm{M}) \\ \text { ionica Wagner, } 1984 & \mathrm{CZ}(\mathrm{M})\end{array}$

\section{MORMIINA}

Jovamormia Ježek, 1983

caliginosa (Eaton, 1893)

$\mathrm{CZ}(\mathrm{M})$

Katamormia Ježek, 1984

bezzii Salamanna, 1983

$\mathrm{CZ}(\mathrm{B} * \mathrm{M})$

strobli Ježek, 1986

$\mathrm{CZ}$ (B M)

Lepimormia Enderlein, 1936

niesiolowskii (Wagner, 1985) CZ ( M)

Mormia Enderlein, 1935

palposa (Tonnoir, 1919)

SK

revisenda (Eaton, 1893)

$\mathrm{CZ}(\mathrm{M})$

Oomormia Ježek, 1984

andrenipes (Strobl, 1910)

CZ (B M) SK

Promormia Ježek, 1983

eatoni (Tonnoir, 1940)

silesiensis Ježek, 1983

CZ (B M) SK

Psychomormia Ježek, 1983

Taramormia Ježek, 1984

caspersi (Wagner, 1977)

$\mathrm{CZ}(\mathrm{M})$

$\mathrm{CZ}$ (B M)

pulcherrima (Wagner, 1979)

$\mathrm{CZ}(\mathrm{M}) \mathrm{SK}$

Yomormia Ježek, 1984

tatrica Ježek, 1984

CZ ( M) SK 
Clogmia Enderlein, 1937

Jungiella Vaillant, 1972

albipunctata (Williston, 1893)

CZ (B M) SK

subg. Jungiella s. str.

hygrophila Ježek, 1987

CZ (B M) SK

jadarica Krek, 1979

$\mathrm{CZ}(\mathrm{M})$

laetabilis Krek, 1979

$\mathrm{CZ}(\mathrm{M})$

septentrionalis Krek, 1979

$\mathrm{CZ}$ (B M)

soleata (Walker, 1856)

CZ (B M) SK

subg. Psychocha Ježek, 1983

valachica (Vaillant, 1963)

CZ (B M) SK

acuminata (Szabó, 1960)

aquatica Ježek, 1983

CZ (B M) SK

hassiaca Wagner, 1993

$\mathrm{CZ}(\mathrm{B})$

$\mathrm{CZ}$ (B M)

janiki Omelková \& Ježek, 2017

$\mathrm{CZ}$ (B M)

laminata (Szabó, 1960)

CZ (B M) SK

procera Krek, 1971

CZ (B M)

ripicola (Bellier, 1967)

subg. Psychogella Ježek, 1984

bohemica Ježek, 1979

$\mathrm{CZ}(\mathrm{B} \mathrm{M})$

inundationum Ježek, 1997

$\mathrm{CZ}(\mathrm{B})$

$\mathrm{CZ}(\mathrm{B})$

Krivosheinoscopus Ježek, 2001

bartai Ježek, 2004

Lepiseodina Enderlein, 1937

$$
\begin{aligned}
& \text { rothschildi (Eaton, 1912) } \\
& \text { tristis (Meigen, 1830) }
\end{aligned}
$$

$\mathrm{CZ}(\mathrm{B} \mathrm{M})$

CZ (B M) SK

CZ (B M) SK

Panimerus Eaton, 1913

albifacies (Tonnoir, 1919)

CZ (B M)

CZ (B M)

denticulatus Krek, 1971

$\mathrm{CZ}(\mathrm{B})$

falcariformis Wagner, 1977

CZ (B M)

goodi Vaillant \& Withers, 1992

kreki Vaillant, 1972

$\mathrm{CZ}(\mathrm{M})$

$\mathrm{CZ}(\mathrm{B})$

$\mathrm{CZ}(\mathrm{B})$

CZ (B M) SK

notabilis (Eaton, 1893)

$\mathrm{CZ}(\mathrm{M})$

unae Krek, 1977

$\mathrm{CZ}(\mathrm{B})$

Parajungiella Vaillant, 1972

verneysicus Vaillant, 1972

bohdanecensis Ježek \& Hájek, 2007

Paramormia Enderlein, 1935

$\begin{array}{ll}\text { consors (Eaton, 1893) } & \text { CZ (B ) } \\ \text { ellisi (Withers, 1987) } & \text { CZ (B M) SK } \\ \text { longicornis (Tonnoir, 1919) } & \text { CZ (B M) SK } \\ \text { prikryli Ježek, 1999 } & \text { CZ (B M) SK } \\ \text { pseudolongicornis (Wagner, 1975) } & \\ & \text { CZ (B M) SK } \\ \text { serbica (Krek, 1985) } & \text { CZ (B M) SK }\end{array}$

polyascoidea (Krek, 1971)

CZ (B M) SK

subg. Duckhousiella Vaillant, 1972

cornuta Nielsen, 1964

$\mathrm{CZ}(\mathrm{B})$

ustulata (Walker, 1856)

CZ (B M) SK

subg. Phyllotelmatoscopus Vaillant, 1982

acuta (Krek, 1971)

CZ (B M) SK 
Peripsychoda Enderlein, 1935

auriculata (Haliday in Curtis, 1839)

fusca (Macquart, 1826)

CZ (B M) SK

zbytka Ježek, 2004

CZ (B M) SK

$\mathrm{CZ}(\mathrm{B})$

Psycmera Ježek, 1984

integella (Jung, 1956)

CZ (B M) SK

Seoda Enderlein, 1935

$\begin{array}{ll}\text { britteni } \text { (Tonnoir, 1940) } & \text { CZ (B M) } \\ \text { carpathica Ježek, 1988 } & \text { CZ ( M) SK } \\ \text { carthusiana (Vaillant, 1972) } & \text { CZ (B M) SK } \\ \text { gressica (Vaillant, 1972) } & \text { CZ (B M) } \\ \text { hajeki Ježek, 1997 } & \text { CZ (B ) } \\ \text { labeculosa (Eaton, 1893) } & \text { CZ (B M) }\end{array}$

Telmatoscopus Eaton, 1904

advena Eaton, 1893

CZ (B M) SK

TRICHOPSYCHODINA

Feuerborniella Vaillant, 1971

Philosepedon Eaton, 1904

$$
\text { obscura (Tonnoir, 1919) CZ (B M) }
$$

subg. Philosepedon s. str.

austriacum Vaillant, 1974

CZ (B M) SK

dumosum Omelková \& Ježek, 2012

hrudkai Ježek, 1999

$\mathrm{CZ}(\mathrm{B} \mathrm{M})$

$\mathrm{CZ}(\mathrm{B} \mathrm{M})$

humerale (Meigen, 1818)

CZ (B M) SK

kowarzi Ježek, 1997

$\mathrm{CZ}(\mathrm{B})$

nickerli Ježek, 1997

$\mathrm{CZ}(\mathrm{B} \mathrm{M})$

perdecorum Omelková \& Ježek, 2012

subg. Trichosepedon Krek, 1999

pragense Ježek, 1997

CZ (B M)

$\mathrm{CZ}(\mathrm{B} \mathrm{M})$

balkanicum Krek, 1971

CZ (B M) SK

subg. Philothreticus Krek, 1999

soljani Krek, 1971

CZ (B M)

Threticus Eaton, 1904

arvernicus Vaillant, 1972

CZ (B M)

balkaneoalpinus Krek, 1972

$\mathrm{CZ}(\mathrm{M}) \mathrm{SK}$

incurvus Krek, 1972

$\mathrm{CZ}$ (B M) SK

lucifugus (Walker, 1856)

negrobovi Vaillant, 1972

CZ (B M) SK

$\mathrm{CZ}(\mathrm{M}) \mathrm{SK}$

silvaticus Ježek, 1985

CZ (B M) SK

Trichopsychoda Tonnoir, 1922

hirtella (Tonnoir, 1919)

CZ (B M) SK

\section{PSYCHODINI}

Apsycha Ježek, 2007

Chodopsycha Ježek, 1984

pusilla (Tonnoir, 1922)

CZ (B M) SK

buxtoni (Withers, 1988)

CZ (B M) SK

lobata (Tonnoir, 1940) CZ (B M) SK

Copropsychoda Vaillant, 1971

brevicornis (Tonnoir, 1940) CZ (B M) SK

Logima Eaton, 1904

albipennis (Zetterstedt, 1850)

CZ (B M) SK

CZ (B M) SK

CZ (B M) SK 
sigma (Kincaid, 1899)

zetterstedti Ježek, 1983

Psycha Ježek,

Psychoda Latreille, 1796

grisescens (Tonnoir, 1922)

alticola Vaillant, 1973

crassipennis Tonnoir, 1940

phalaenoides (Linnaeus, 1758)

Psychodocha Ježek, 1984

uniformata Haseman, 1907

cinerea (Banks, 1894)

elegans (Kincaid, 1897)

gemina (Eaton, 1904)

itoco (Tokunaga \& Komyo, 1955)

Psychodula Ježek, 1984

minuta (Banks, 1894)

Psychomora Ježek, 1984

mycophila (Vaillant, 1988)

trinodulosa (Tonnoir, 1922)

Tinearia Schellenberg, 1803

alternata (Say, 1824)

lativentris (Berdén, 1952)

Ypsydocha Ježek, 1984

setigera (Tonnoir, 1922)
CZ (B M) SK

CZ (B M) SK

CZ (B M) SK

CZ (B M) SK

$\mathrm{CZ}(\mathrm{B} \mathrm{M})$

CZ (B M) SK

CZ (B M) SK

$\mathrm{CZ}$ (B M) SK

$\mathrm{CZ}(\mathrm{B})$

CZ (B M) SK

CZ (B M)

CZ (B M) SK

CZ (B M)

CZ (B M) SK

CZ (B M) SK

CZ (B M) SK

CZ (B M) SK

\section{PERICOMINI}

Berdeniella Vaillant, 1976

$\begin{array}{lr}\text { chvojkai Ježek, } 1999 & \text { CZ (B M) } \\ \begin{array}{l}\text { desnensis Ježek, 2006 } \\ \text { gardinii Salamanna \& Raggio, } 1984\end{array}\end{array}$

Clytocerus Eaton, 1904

subg. Boreoclytocerus Duckhouse, 1978

dalii (Eaton, 1893)

longicorniculatus Krek, 1987

ocellaris (Meigen, 1804)

rivosus (Tonnoir, 1919)

splendidus Ježek \& Hájek, 2007

$\mathrm{CZ}(\mathrm{M}) \mathrm{SK}$

helvetica (Sarà, 1957)

kocii Ježek, 2006

SK

$\mathrm{CZ}(\mathrm{B} \mathrm{M}) \mathrm{SK}$

$\mathrm{CZ}(\mathrm{B} * \mathrm{M})$

manicata (Tonnoir, 1920)

matthesi (Jung, 1954)

pyrenaica Vaillant, 1976

stavniensis (Krek, 1969)

$\mathrm{CZ}(\mathrm{B} \mathrm{M}) \mathrm{SK}$

$\mathrm{CZ}(\mathrm{B} \mathrm{M}) \mathrm{SK}$

CZ (B M)

CZ (B M) SK

$\mathrm{CZ}$ (B M) SK

CZ (B M) SK

CZ (B M) SK

CZ (B M) SK

CZ (B M) SK

CZ (B M) SK

tetracorniculatus Wagner, 1977

Parabazarella Vaillant, 1983

subneglecta (Tonnoir, 1922)

CZ (B ) SK

CZ (B M) SK

CZ (B M) SK

Pericoma Walker, 1856

subg. Pericoma s. str.

calcilega Feuerborn, 1923

CZ (B ) SK

CZ ( M) SK

CZ (B M) SK

exquisita Eaton, 1893

CZ ( M) SK 
pallida Vaillant, 1978

pannonica Szabó, 1960

pingarestica Vaillant, 1978

pseudexquisita Tonnoir, 1940

tatrica Szabó, 1960

tonnoiri Vaillant, 1978

trifasciata (Meigen, 1804)

vestita Vaillant \& Withers, 1993

subg. Pachypericoma Vaillant, 1978

blandula Eaton, 1893

fallax Eaton, 1893

nielseni Kvifte, 2010

Pneumia Enderlein, 1935

canescens (Meigen, 1804)

compta (Eaton, 1893)

cubitospinosa (Jung, 1954)

fonticola (Szabó, 1960)

gracilis gracilis (Eaton, 1893)

kabelaki Omelková \& Ježek, 2012

mutua (Eaton, 1893)

nubila (Meigen, 1818)

palustris (Meigen, 1804)

pilularia (Tonnoir, 1940)

plumicornis (Tonnoir, 1922)

rivularis (Berdén, 1954)

stammeri (Jung, 1956)

tjentistensis Krek, 1969

trivialis (Eaton, 1893)

vittata (Tonnoir, 1919)

Saraiella Vaillant, 1973

Szaboiella Vaillant, 1979

parva (Vaillant, 1963)

rotunda (Krek, 1970)

hibernica (Tonnoir, 1940)

Tonnoiriella Vaillant, 1971

nigricauda (Tonnoir, 1919)

pulchra (Eaton, 1893)

sieberti Wagner, 1993

Ulomyia Walker, 1856

annulata annulata (Tonnoir, 1919)

cognata (Eaton, 1893)

fuliginosa (Meigen, 1804)

plumata (Tonnoir, 1919)

undulata (Tonnoir, 1919)

vaseki Ježek, 2002
CZ (B M) SK

$\mathrm{CZ}(\mathrm{M})$

CZ (B M) SK

CZ (B M) SK

SK

CZ ( M) SK

CZ (B M) SK

CZ ( M) SK

CZ (B M) SK

CZ (B M) SK

CZ (B M) SK

CZ (B M) SK

CZ ( M) SK

CZ (B M) SK

CZ ( M) SK

CZ (B M) SK

$\mathrm{CZ}(\mathrm{M}) \mathrm{SK}$

CZ (B M) SK

CZ (B M) SK

CZ (B M) SK

CZ (B M) SK

CZ (B M) SK

CZ (B M) SK

CZ (B M) SK

$\mathrm{CZ}(\mathrm{M})$

CZ (B M) SK

CZ (B M) SK

CZ (B M) SK

$\mathrm{CZ}$ (B M) SK

CZ (B M) SK

CZ (B M) SK

CZ (B M) SK

$\mathrm{CZ}(\mathrm{M}) \mathrm{SK}$

\section{Summary}

$\mathrm{CZ}$ (B M) SK

CZ (B M) SK

CZ (B M) SK

$\mathrm{CZ}$ (B M)

$\mathrm{CZ}$ (B )

CZ (B M) SK

$178(147160) 119$

\footnotetext{
* New record

** Record on a basis of a molecular analysis without the specimen evidence in contrast to the following checklist data
} 